\title{
WestVirginiaUniversity
}

THE RESEARCH REPOSITORY @ WVU

Graduate Theses, Dissertations, and Problem Reports

2004

\section{Price protection options for West Virginia beef cattle producers}

Matthew C. Kleski

West Virginia University

Follow this and additional works at: https://researchrepository.wvu.edu/etd

\section{Recommended Citation}

Kleski, Matthew C., "Price protection options for West Virginia beef cattle producers" (2004). Graduate Theses, Dissertations, and Problem Reports. 1975.

https://researchrepository.wvu.edu/etd/1975

This Thesis is protected by copyright and/or related rights. It has been brought to you by the The Research Repository @ WVU with permission from the rights-holder(s). You are free to use this Thesis in any way that is permitted by the copyright and related rights legislation that applies to your use. For other uses you must obtain permission from the rights-holder(s) directly, unless additional rights are indicated by a Creative Commons license in the record and/ or on the work itself. This Thesis has been accepted for inclusion in WVU Graduate Theses, Dissertations, and Problem Reports collection by an authorized administrator of The Research Repository @ WVU. For more information, please contact researchrepository@mail.wvu.edu. 
Price Protection Options for West Virginia Beef Cattle Producers

Matthew C. Kleski

Thesis submitted to the

Davis College of Agriculture, Forestry, and Consumer Sciences

at West Virginia University

in partial fulfillment of the requirements

for the degree of

Master of Science

in

Agricultural and Environmental Education

Harry N. Boone, Jr., Ph.D., Chair

Thomas R. McConnell, Associate Professor

Stacy A. Gartin, Ph.D.

Deborah A. Boone, Ph.D.

Division of Resource Management

Morgantown, West Virginia

2004

Keywords: Price Protection, Revenue Insurance, Livestock Pricing, West Virginia Beef Cattle Prices, Risk Management Options 


\section{ABSTRACT \\ Price Protection Options for West Virginia Beef Cattle Producers}

\section{Matthew C. Kleski}

The purpose of this study was to determine if a price protection option would be beneficial to West Virginia's beef cattle industry. Fourteen years of price data were used to determine an average price for cattle based on weight, sex, breed and grade. The study used cattle lots of 9,000 pounds or greater with individual weights of 600 pounds or greater. Four case studies were used to analyze individual producer prices against the state averages. It was found that by comparing individual price data with the state sale averages that pricing trends could be determined to identify years when prices were a challenge to producers. This allowed conclusions to be made on the use of price protection options. It was also found that when cattle are fed to reach the 800 pound level that they are at less price risk than when they are sold at 600 to 700 pound groups. 


\section{ACKNOWLEDGEMENTS}

I would like to take this opportunity to thank a few people that have helped me complete the thesis process. The first person that I would like to thank is my advisor Harry N. Boone, Jr. This entire process has been very bearable and manageable due to your assistance and guidance. Your ability to reach the students and your desire to see them succeed is very much appreciated. You are able to make the entire thesis process seem very easy, even when it comes to those dreaded statistics. The guidance and personal interest that you have shown in assisting me in selecting a topic, focusing the research and making it through the defense and in the final stages

of completion is certainly appreciated. Your help and guidance has helped me to grow as both a researcher and a student.

The next person that I would like to thank is the person that helped to bring me to West Virginia University, Thomas R. McConnell. You have given me a tremendous opportunity to come to West Virginia and learn about the livestock industry and agriculture across the state. This has been an amazing trip for me to see how agriculture varies by state and how each location does its part to make the whole of agriculture prosper. You gave me the opportunity to work with you for my entire stay at WVU and I appreciate that greatly. You have opened the door to a whole new perspective in regards to risk management. This is an area that I wasn't completely familiar with when I started my work, but I have grown to have a deep interest in the field and it will play a major role in my future. The livestock revenue programs that I have assisted you with are truly role-model status and will be used to help hundreds and thousands of farmers not only in West Virginia, but also across the country. I deeply appreciate all the help and guidance that you have given me during my time at WVU and as your Research 
Assistance. The farmers of West Virginia are very lucky to have someone working as hard as you do to help them be successful and profitable.

I would also like to thank my other committee members, Deborah A. Boone and Stacy A. Gartin. I would like to thank both of you for serving on my committee. I feel that you have both brought perspectives to the table that has helped to strengthen my research and thesis as a whole. Now from one Buckeye to another I would like to thank Deborah A. Boone for giving me great guidance in my coursework at WVU. I am sorry that you had me in class every semester that I have been here, but it has been a great learning experience and I appreciate your concern for the students and your push to make us succeed. It has been a very rewarding and beneficial experience. Now to Stacy A. Gartin, I would like to thank you for being there to answer my questions when I wasn't sure exactly what my next step was going to be. Your dedication to the Agricultural Education program at West Virginia University is greatly appreciated. You are making strides to make the department all about the students and that means a great deal to me. This has been a very rewarding experience for me.

I would like to thank my parents, Ed and Adair Kleski. Thank you for supporting me in my decision to return to school and work on my Master's Degree. Never in a million years did I think that I would be back in school working on another degree, but agriculture has definitely got a hold of me and led me down my educational path and will guide my future. I would also like to thank my grandparents, Ed and Ethel Kleski. Looking back I think that you have had a great impact on my career field and field of study. I guess all those trips to the local auction market must have had more of an impact than anyone really knew. Our little farm in Ohio has opened up a lot of doors for me and who knew that my first little Christmas present heifer, Queen, would help to build the interest in agriculture and get me to where I am today. Lastly, I would like to 
thank my grandfather Gene Parks. You have always been a great supporter of the whole education process and encouraged all of us to continue down the educational trail until you are at the end of the road. Well I have taken the next step, there is only one more left. 


\section{TABLE OF CONTENTS}

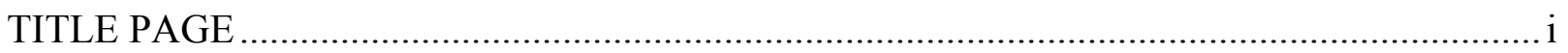

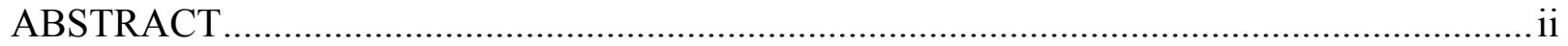

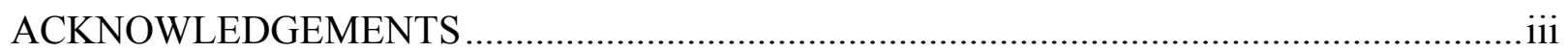

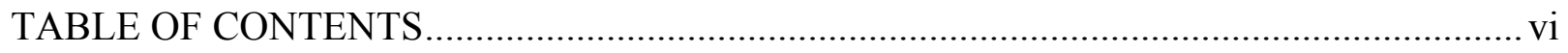

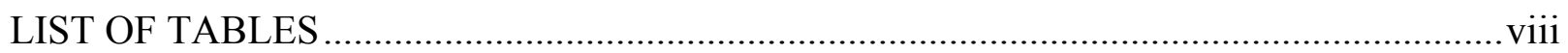

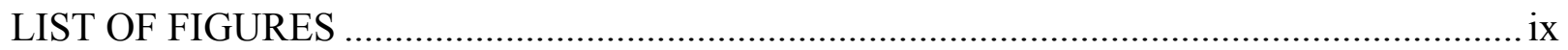

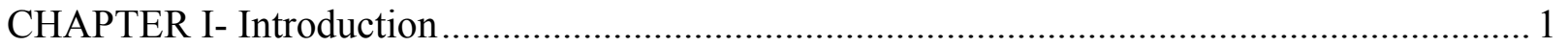

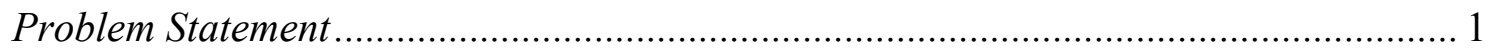

Purpose of the Study ............................................................................................. 2

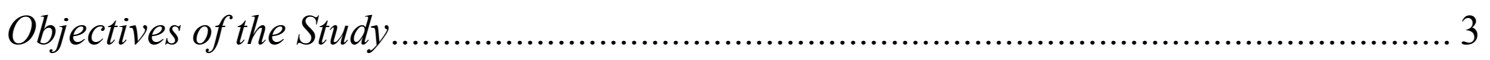

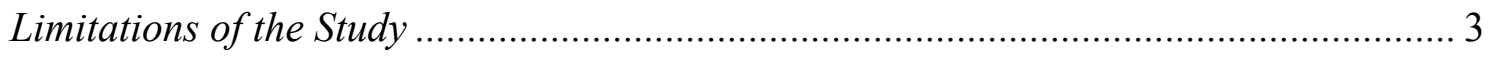

CHAPTER II- Review of Literature ................................................................................. 5

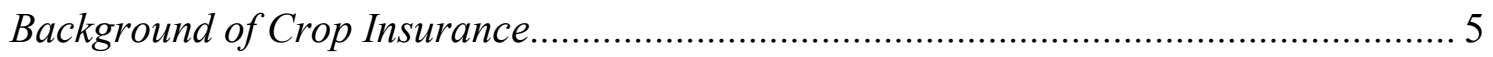

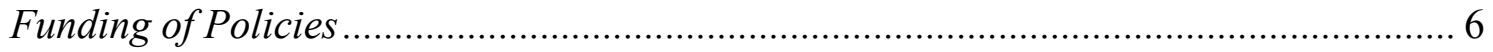

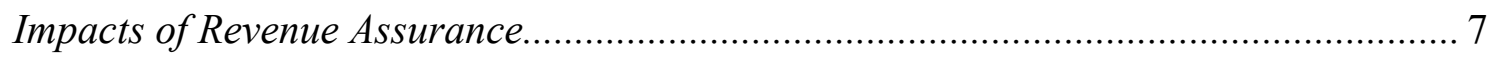

Price Risk with Stocker Cattle ……....................................................................... 7

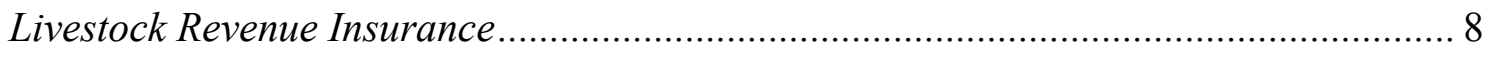

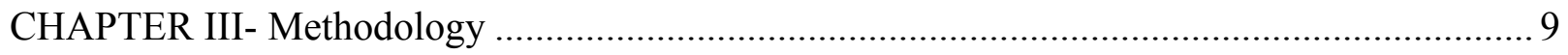

Population and Instrumentation of the Case Studies.................................................. 10

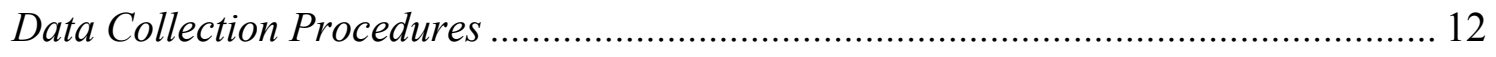

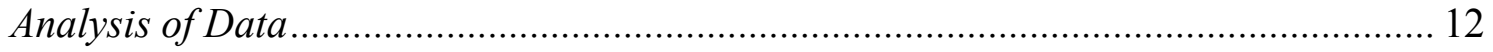




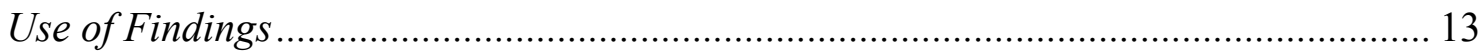

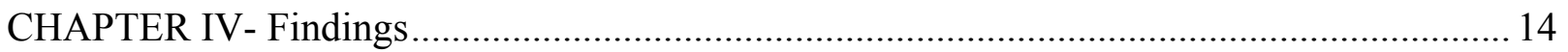

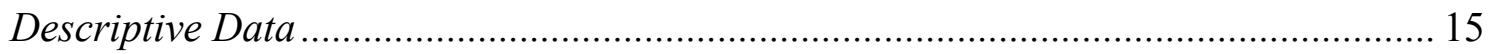

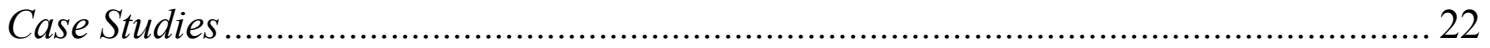

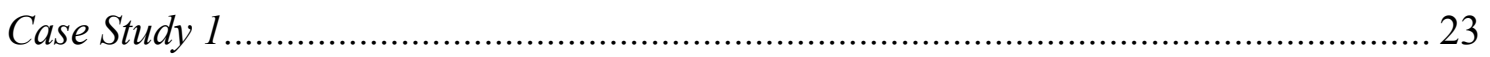

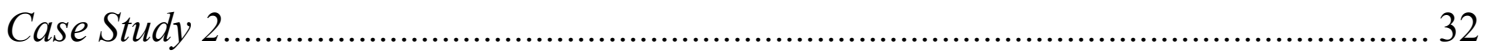

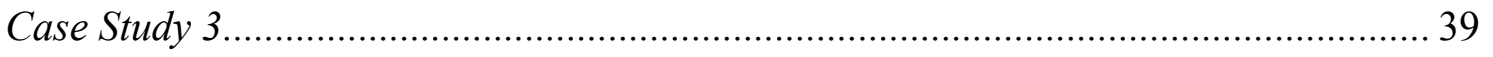

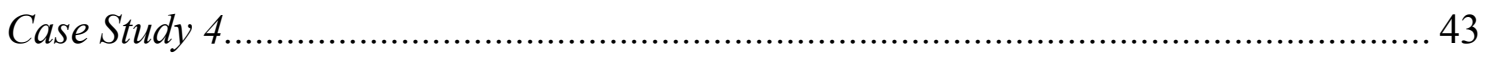

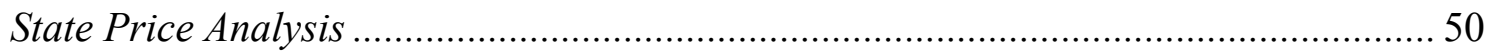

CHAPTER V- Summary, Conclusions and Recommendations .......................................... 53

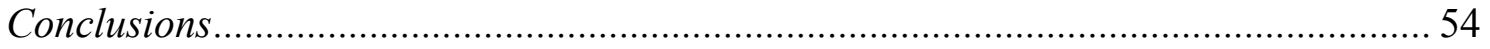

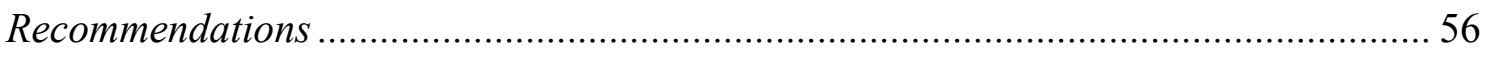

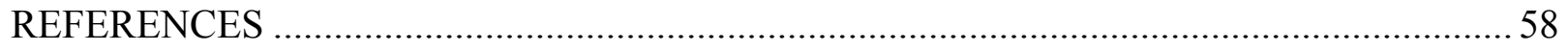

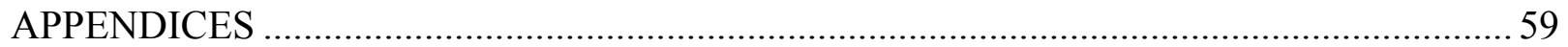

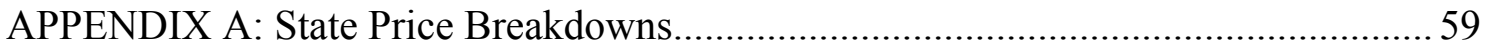

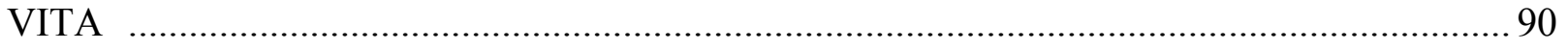




\section{LIST OF TABLES}

Table Title Page

1. Total Head on Each Data Set ...................................................................... 15

2. Monthly Breakdown of Cattle Sales ..............................................................17

3. Breakdown of Grades ............................................................................ 18

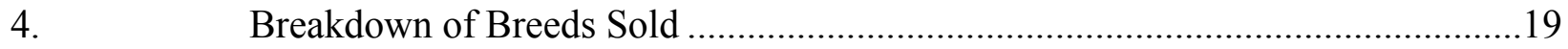

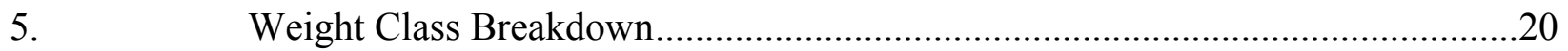

6. AGR-Lite Regions Cattle Sold Through....................................................22

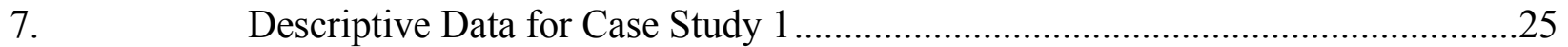

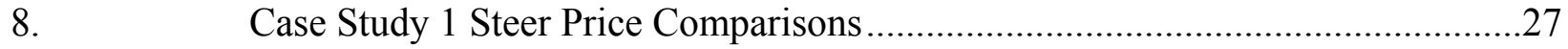

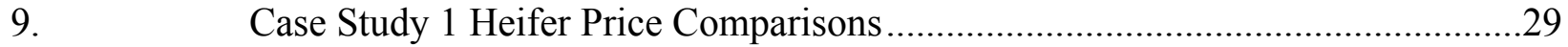

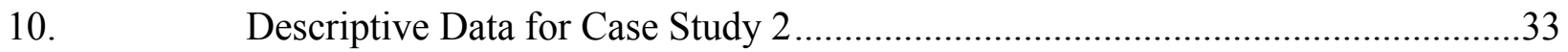

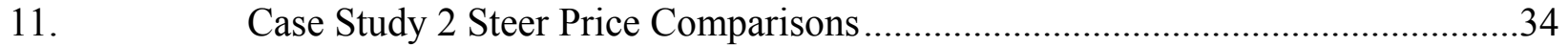

12. Case Study 2 Heifer Price Comparisons ...........................................................36

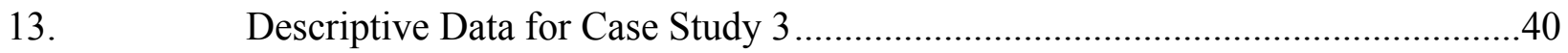

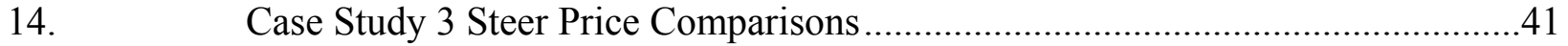

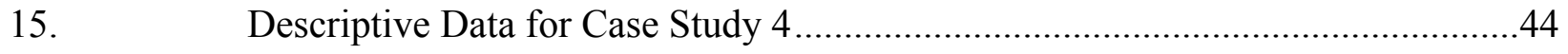

16. Case Study 4 Steer Price Comparisons .....................................................45

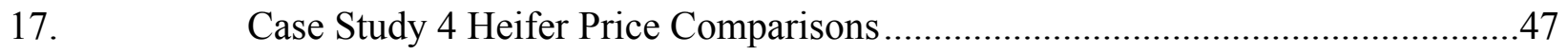

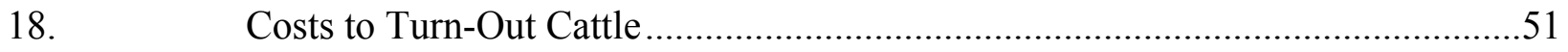

19. Estimated Weight and Price Sales Comparison ..............................................52 


\section{LIST OF FIGURES}

Figure Title Page

1. West Virginia Revenue Risk Groups, Proposed 2003 ..................................21

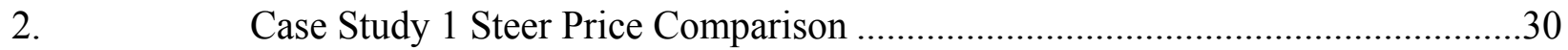

3. Case Study 1 Heifer Price Comparison ............................................................ 31

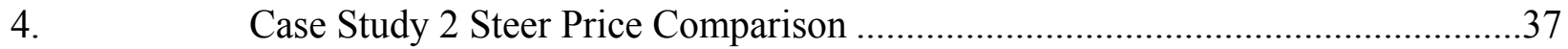

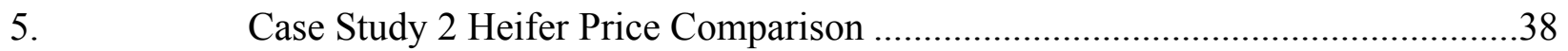

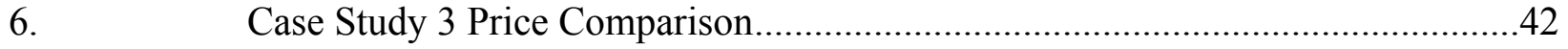

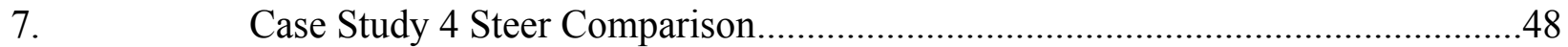

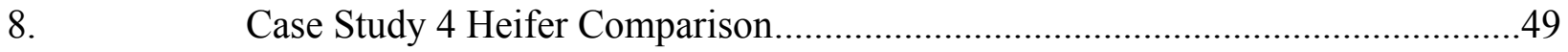




\section{CHAPTER I}

Introduction

\section{Problem Statement}

Price risks of livestock products have always been a major challenge for producers nationwide. In many agricultural commodities, such as row crops, small grains and tree fruits, price and yield protection crop insurance products have been developed by the United States Department of Agriculture (USDA) in order to provide market and yield stability in times of hardship. The government seeks to insure the income of farmers against the occasional crop failure and price decrease. In most cases farmers are able to purchase insurance policies that will provide payment to them should their production fail or reach expected market prices. A farm price protection option is specified on whether the revenue insured is related to the entire farm or if it will be based on individual crop protection (Hennessy, Babcock \& Hayes, 1997). Livestock has been left out of risk management and price protection programs.

In the beef cattle industry market prices fluctuate based on consumer demand and supply of beef products. In many cases outside factors inhibit cattle production and ultimately affect cattle prices. In years of drought, tornadoes, floods or other natural disasters there has never been an option to help livestock producers recover their production costs or revenue shortfalls. In addition, there has never been an insurance product to help maintain market prices or livestock options when the market place is oversupplied with beef products.

Research into the options available for such a program will help producers understand if a beef cattle price protection option is something that would provide additional market stability. This concept has the potential to allow for a more stable beef industry, while allowing for sustainability within this sector of production. Currently, without the alternative of buying price 
protection, cattle producers must look elsewhere to find sources of protection and stability against the market. These sources include more complex forms of pricing strategies than crop producers who are offered USDA subsidized programs (McKissick, Martin, \& Kolajo, 1989).

Presently there are several price protection alternatives that help reduce risk, but all are somewhat complicated for the average livestock producer to take part in. These processes include forward pricing through futures markets and the options market (McKissick, Martin, \& Kolajo, 1989). These options involve complicated contracting and marketing cattle and are often times too expensive for producers to participate resulting in the farmers not managing their risks against sudden market drops.

In recent years, several new insurance products have been introduced for the crop sector and the forward progression of these particular options has helped to establish a need and necessity to address the needs of livestock producers. Attempting to provide fair and adequate pricing options while trying to make the livestock options fit within the parameter of existing crop insurance programs is the major challenge of livestock insurance protection. In all cases the benefits to producers would need to exceed the cost of the product itself (Hart, Babcock, \& Hayes 2000).

Purpose of the Study

The purpose of this study was to analyze price data for yearling beef cattle sold in the state of West Virginia between 1988 and 2003 to determine if a price protection option in yearling cattle production was feasible and obtainable. This study analyzed price trends over the period and identified the times when prices made it impossible for producers to make a profitable return on their product. This study identified market trends, including the evaluation of how weight classes impact price received. The study analyzed prices in relation to gain and analyzed 
market potential for various weight groups. It also examined how various factors such as seasons of the year and weather patterns affected cattle prices. Statistical correlations were examined between color of cattle, grade of cattle and weight of cattle and how they affected the overall price and salability of the cattle.

This study used an ex post facto research design. Case studies were utilized to compare individual producer prices versus statewide prices. The comparisons between the data sets allowed for research into regional pricing and local challenges that other West Virginia producers do not encounter. The comparison data sets also provided a window of research into price protection and allowed the researcher to analyze how the individuals in the case study could have benefited from price protection options.

\section{Objectives}

The objectives of this study were to 1) identify beef cattle pricing trends over the past fourteen years, 2) study individual beef producer pricing trends to compare cattle and compare them with the state average, as well as, 3) analyze market challenges present in West Virginia. In identifying the stated objectives the data will allow the researcher to 4) determine how market price protection could potentially benefit the state's cattle producers.

\section{Limitations}

The limitations of this study were that the case studies consisted of a small and purposively selected group of beef cattle producers. These farmers were selected on the basis of being able to provide actual pricing records to depict their individual profit margins and losses over the course of the fourteen-year period. Another limitation was getting producers to voluntarily provide financial records to be included into the study. 
This particular study focused on a topic that has not had a great deal of research. This topic was very new and innovative in the livestock sector, but is something that has been identified as a major component to secure future farmer stability and allow for farmers to manage risks. 


\section{CHAPTER II}

\section{Review of Literature}

The formation of price protection and insurance protection being offered to farmers and producers is not a new concept in the agriculture industry, however price protection for beef cattle producers is a very new concept. Revenue insurance was initially introduced in the United States as far back as 1983 (U.S. Congress, CBO). Through the years this protection has helped farmers survive natural disasters, years of poor production, and assisted in providing protection against the unknown.

\section{Background of Crop Insurance}

In an effort to understand the backing and formation principles, an analysis of crop insurance models must be completed. Crop insurance and revenue insurance have very different coverage foundations, but both offer a basis for risk protection. In understanding crop insurance, it can be stated that the government seeks to assure the income of farmers against the occasional occurrence of low revenue levels. The initial challenge in creating a farm price protection is to specify whether the revenue insured is related to the entire farm or if it will be based on individual crops (Hennessy, Babcock, \& Hayes, 1997). In most cases the protection is offered on the individual crop and separate insurance will be purchased to cover the entire farm. This is where revenue insurance gives the farmer a similar but very different price protection option. Crop insurance provides farmers with risk protection for individual crops, making multiple coverage purchases necessary. In contrast, revenue insurance protects against total farm revenue losses leaving out the causes of those particular losses and covering multiple production sectors in one insurance policy. 
A challenge arises in crop insurance when decisions are made on qualifications or stipulations that must be put into the policy. A major issue in crop protection production is yield. A decision is required whether yield bases will be based on individual crop production or based on an average of the location area. In most cases a local average is used in order to prevent false reporting. Many additional factors build on prediction of yields for example, types of soil, types of seed and crop management. In many cases proper yields and expectations can not be predicted (Hennessy, et al., 1997).

The final aspect of the contract is whether the crop insurance will be based on actual plantings or it will be formulated on historic plantings. In most scenarios it is better to base the price protection on a historic planting basis because it will more likely coincide with crop insurance options available and will assist in preventing farmers from entering into high-risk crops that would require less expenditures but use the current land layout. However, you must be able to develop a common trend in your production and analyze the basis for what you choose to predict (Hennessy, et al., 1997).

Funding of Policies

Funding for the price protection options can often be a challenge. However, emergency funds are allocated towards natural disasters and relief funds that could be proactively directed towards insurance policies or buying options. Every year between 1988 and 1994, Congress has funded agricultural emergency relief measures to help rebuild or redistribute crop damages. With the funding available each year, it would be simple to direct it towards protection policies in a proactive rather than reactive manner (Innes, 2003).

In essence, the ex post funding option is designed to assist or bail out farmers in situation of financial upheaval. However, an ex ante policy allowing for farmers to buy commodity 
protection would allow for funds to be allocated accordingly and significantly reduce the need for disaster relief (Innes 2003).

\section{Impacts of Revenue Assurance}

Instability is a major factor in agriculture production and the variety of contributing factors is enormous. Issues can be brought forth by weather, disease, insects, yields and ultimately prices. This leads to variation in individual producer yields and prices and provides for price risks for producers. In addition, producer price risk can be elevated by the inelastic demand for agricultural products; this ultimately creates income risk for producers. With these

know principles revenue insurance is a building block to giving farmers a whole farm protection against risk, not just individual crop protection (Gray, Richardson, \& McClaskey, 1994).

\section{Price Risk with Stocker Cattle}

Currently, without the alternative of buying price protection cattle producers must look elsewhere to find sources of protection and stability against the market. This includes more complex forms of pricing strategies than crop producers who are offered government pricing programs (McKissick, Martin, \& Kolajo, 1989). At the present time several pricing alternatives exist to help reduce risk, but all are somewhat complicated for the average producer to take part in. These processes include forward pricing through futures markets and the options market. However, these options involve contracting and marketing cattle and include steps that are not necessary to protect yourself and your livestock from a sudden market dropout. These steps often times place large entry barriers and margin prices that are not the best solution for every producer. Large farms with substantially higher revenues may be able to put up these price options, but for small farmers it is often times impossible to overcome those barriers (McKissick, Martin, \& Kolajo, 1989). 
With the options previously listed about it is challenging for small operations to use alternative pricing methods. When considering the size of the herd, the costs of trading and selling, it often becomes a large financial burden to use these markets, where a simple price protection option would assist the smaller producers immensely (McKissick, et al., 1989).

\section{Livestock Revenue Insurance}

In recent years, several insurance products have been introduced for the crop sector, and the forward progression of these particular options has helped to establish a need and necessity to address needs of livestock producers. Currently, through the Center for Agricultural and Rural Development at Iowa State University an in-depth analysis is being done to study what kind of price protection options would be the most effective in providing local producers livestock protection and pricing equation. The study is attempting to provide fair and adequate pricing options while trying to make the livestock options fit within the parameter of existing crop insurance programs. In all cases the benefits to producers would need to exceed the cost of the product itself (Hart, Babcock, \& Hayes, 2000).

In livestock revenue insurance, production risk is much smaller than it is in crop production because cattle are more adaptable to weather and natural occurrences. Most production risks in livestock would occur through disease and low gain rates, but in most cases those factors can be prevented through proper management practices (Hart et al., 2000).

Price risk is the largest component of livestock production. Producers face both input and output risks. Input risks would include feed and hay costs, while output risks would involve the overall market prices. So with the evidence that price risk is the largest factor effecting livestock production, it is essential that programs be created and evaluated to address the needs of protecting farmers and their products. 


\section{CHAPTER III}

\section{Methodology}

\section{Purpose of the Study}

The purpose of this study was to analyze price data for yearling beef cattle sold in the state of West Virginia between 1988 and 2003 to determine if a price protection option in yearling cattle production was feasible and obtainable. This study analyzed price trends over the period and identified the times when prices made it impossible for producers to make a profitable return on their product. This study identified market trends, including the evaluation of how weight classes impact price received. The study analyzed prices in relation to gain and analyzed market potential for various weight groups. It also examined how various factors such as seasons of the year and weather patterns affected cattle prices. Statistical correlations were examined between color of cattle, grade of cattle and weight of cattle and how they affected the overall price and salability of the cattle.

This study used an ex post facto research design. Case studies were utilized to compare individual producer prices versus statewide prices. The comparisons between the data sets allowed for research into regional pricing and local challenges that other West Virginia producers do not encounter. The comparison data sets also provided a window of research into price protection and allowed the researcher to analyze how the individuals in the case study could have benefited from price protection options.

\section{Objectives}

The objectives of this study were to 1) identify beef cattle pricing trends over the past fourteen years, 2) study individual beef producer pricing trends to compare cattle and 3) compare them with the state average, as well as, analyze market challenges present in West Virginia. In 
identifying the stated objectives the data will allow the researcher to 4) determine how market price protection could potentially benefit the state's cattle producers.

\section{Population and Instrumentation of the Case Studies}

The population for the case studies was four purposefully selected farmer/ producers.

Farmers were selected from across the state of West Virginia based on the following criteria:

- Must sell at least one graded lot of cattle within a year's time.

- Must have price data for at least consecutive years.

- Must be willing to share pricing information and sales receipts with the researcher.

- Individual calf weights must be 600 pounds or greater.

- Lot weights must be 9,000 pounds or greater.

Individual sale receipts were limited to the calculation of profits and to determine the benefits of a potential price protection option and was strictly based on end point performance prices. The study attempted to trace price trends throughout the state of West Virginia as well as trace the individual producer prices to test the potential benefits of a price protection program. The case studies examined product prices and compared the producer prices received and the average corresponding state price to identify years that a price protection option would have assisted the producer.

Within the study six data sets were collected and analyzed. The first data set, served as the base set and consisted of yearling cattle pricing data from all livestock auctions in West Virginia. This particular data set was initially collected for additional research projects and as available for further analysis with this data set sale prices and receipts were recorded from 1988- 
2003. This allowed for in-depth analysis of market cattle prices during that time period and ultimately provided the base set of prices to compare the case study groups to. The second data set was a light weight cattle data set compiled using the same market auctions across the state. This allowed for studying the entry cost prices for the cattle market. The four remaining data sets were records and sales of the four producers used in the case studies.

In the base study group information was collected on the following variables; sale date, location, breed/color of cattle, sex of cattle, number of head in the lot, total lot weight, average head weight, price per pound and overall price for the lot. In addition, records were limited to cattle lot weights of 9,000 pounds or greater with average weight greater than 600 pounds. This allowed for price adjustments on each of the given variables. It was expected that prices would vary depending on weight, color and sex of the cattle sold. In the state data set, calculations have been done to determine the standard deviation of the sale cattle in regards to weight groups, sex and year. Further analysis were done to determine the means of the group.

With regards to the case study groups, the same information was collected in on sale date, location, breed/color of cattle, sex of cattle, number of head in the lot, total lot weight, average head weight, price per pound and overall price for the lot. Means and standard deviations were calculated to analyze the differences among the group of cattle, between the case study group and ultimately the difference between each member of the case study group and the base data set.

The data collection procedures allowed for a base group to be used as the overall prices for the state of West Virginia. The case study method allowed for analysis on each member of the case study group to determine if they were at the average, above the average, or below the state average for prices received. This helped to determine if each member of the case study would have benefited from a price protection option for their cattle. 
By comparing the data collected from each producer in the case study, issues to location challenge and environmental factors also came to the forefront. Ultimately, this helped to identify locations and producers that may benefit the most from a price protection option.

\section{Data Collection Procedures}

For this study two different data sets were created. The first data set, which was the base data, was collected by obtaining sale records and sale receipts from all of the major livestock auction markets in the state of West Virginia. Each sale market was contacted individually and records were copied and compiled into one major Microsoft Excel database. Prices from auction markets on file with the West Virginia University Extension Service were also used.

For the case study portion, each producer was contacted individually. Appointments were made and visits were set up to obtain the producer records. The producer records were kept confidential and the farmers name and information were not disclosed at any portion of this study. Records were used to make comparisons between individual producer prices and prices found to be state averages. Each farmer was issued a number to identify them as separate individuals, numbers and corresponding names were not published. Records were compiled into one major Microsoft Excel database identifying each producer only by number. Analysis of Data

In analyzing the data, the base set data was broken to identify the years that the cattle were sold in and weight of the cattle sold. The data set was also broken in weight increments of 100, beginning with 600 pounds. For example, average prices for the year 2001 were calculated

based on $600,700,800,900$ pounds and so on. Standard deviations were calculated among each weight group as well as an entire year standard deviation of price was calculated. Prices were analyzed in the same manner with in the case study group. 
Standard deviations among the prices along with differences in means were calculated in an attempt to compare the case study group with the base group. Ultimately, this will identify the difference between the state prices and the prices received by each producer. This is where it will become evident if pricing options would have assisted the farmers in the case study. Use of Findings

The use of findings from this study will help to stabilize the need for pricing options for livestock producers within the state of West Virginia. The study will bring light to the flexibility and variability of the entire beef market as well as the variation among individual beef farmers. This will also assist in helping farmers to determine if purchasing pricing options would benefit them. By having the state data set it will allow for more research to be done in regards to pricing trends and how prices or trends can be predicted for West Virginia. In addition, it could allow for more profit share to be earned by West Virginia farmers and keep more farmers in business. 


\section{CHAPTER IV}

\section{Findings}

\section{Purpose of the Study}

The purpose of this study was to analyze price data for yearling beef cattle sold in the state of West Virginia between 1988 and 2003 to determine if a price protection option in yearling cattle production was feasible and obtainable. This study analyzed price trends over the period and identified the times when prices made it impossible for producers to make a profitable return on their product. This study identified market trends, including the evaluation of how weight classes impact price received. The study analyzed prices in relation to gain and analyzed market potential for various weight groups. It also examined how various factors such as seasons of the year and weather patterns affected cattle prices. Statistical correlations were examined between color of cattle, grade of cattle and weight of cattle and how they affected the overall price and salability of the cattle.

This study used an ex post facto research design. Case studies were utilized to compare individual producer prices versus statewide prices. The comparisons between the data sets allowed for research into regional pricing and local challenges that other West Virginia producers do not encounter. The comparison data sets also provided a window of research into price protection and allowed the researcher to analyze how the individuals in the case study could have benefited from price protection options.

\section{Objectives}

The objectives of this study were to identify beef cattle pricing trends over the past fourteen years to study individual beef producer pricing trends to compare cattle and compare them with the state average, as well as, analyze market challenges present in West Virginia. In 
identifying the stated objectives the data will allow the researcher to determine how market price protection could potentially benefit the state's cattle producers.

\section{Findings}

\section{Descriptive Data}

When the data set was initially analyzed, statistics were calculated for each data set. Six data sets made up the study. The data included the statewide yearling data set, which compiled yearling cattle prices from sale markets across the state; the light weight cattle data set, which allowed for studying the entry cost prices for the cattle market; and four data sets from the records and sales of the four producers used as case studies. Table 1 provides the breakdown of the numbers of lots compiled within each data set. The total number of lots of cattle included in the six data sets was 3,759 .

Table 1

Total Head in Each Data Set

\section{Lots Total Head}

\section{Data Set}

$\longrightarrow$

Statewide Yearling Cattle

3,304

N $\%$

N

$\%$

Light Weight Cattle

228

87.9

117338

89.0

Case Study 1

60

6.1

4625

3.5

Case Study 2

77

1.6

2005

1.5

Case Study 3

15

2.0

4866

3.7

Case Study 4

75

0.4

564

.4

Total Data Set

3,759

2.0

2427

1.8

131825 
All six data sets were combined to examine the number of sales reported yearly. The combining of the data sets allowed the researcher to track years of more prominent movement of cattle through the auction markets. In addition to the yearly reports, a monthly report was developed to investigate the more prominent months that cattle were sold in the state (see Table 2). The prominent month data allowed the researcher to examine the months when markets might have higher risks due to an overload of cattle in the marketplace. The prominent monthly analyses lead to a procedure to determine how entry prices and end weights could be used to determine when cattle should be sold and what weight class returned the highest price.

It was found that the majority of yearling cattle in the state of West Virginia were sold in the months of August, September and October. Sales during those three months accounted for $72.9 \%$ of the total cattle sales and accounted for lots of 1,174; 939; and 626 respectively. The next closest month was April with a total of 587 lots or $15.6 \%$ of the sales. April sales were primarily made up of the lighter weight cattle which represented the most probable time that 400 and 500 pound weight cattle entered the market in West Virginia (see Table 2).

The next step in understanding and analyzing the market systems was to analyze the grade and breed or color of the cattle sold within the state. Breeds were identified by the sale markets in all cases except black cattle. All black and black white face (BWF) cattle were categorized based on color because there was no way to identify individual breeds within the black color groups. For the remainder of the study this portion of the data will be referred to as the breed of cattle. This was an important component because buyers will pay different prices for differences in breed and grade. The majority of cattle sold in West Virginia were medium (M) grade cattle. The M grade accounted for 2,780 lots (74.0\%) of the total sales (see Table 3). Black 
cattle dominated the market place with 1,904 lots (50.7\%) of the total sales. The next closest breed group was black white face (BWF) cattle with 850 sale lots (22.6\%) (see Table 4). Table 2

Monthly Breakdown of Cattle Sales

\begin{tabular}{lrrrr}
\hline \multirow{2}{*}{ Month } & \multicolumn{2}{c}{ Lots } & \multicolumn{2}{c}{ Total Head } \\
\cline { 2 - 5 } & $\boldsymbol{N}$ & $\%$ & $\boldsymbol{N}$ & $\%$ \\
\hline January & 9 & 0.2 & 326 & 0.2 \\
February & 15 & 0.4 & 569 & 0.4 \\
March & 38 & 1.0 & 1,402 & 1.1 \\
April & 587 & 15.6 & 17,303 & 13.1 \\
June & 1 & 0.0 & 12 & 0.0 \\
July & 277 & 7.4 & 8,771 & 6.7 \\
August & 1,174 & 31.2 & 40,209 & 30.5 \\
September & 939 & 25.0 & 39,029 & 29.6 \\
October & 626 & 16.7 & 20,683 & 15.7 \\
November & 70 & 1.9 & 2,427 & 1.8 \\
December & 23 & 0.6 & 1,094 & 0.8 \\
& & & 131,825 & 100.0 \\
\hline
\end{tabular}


Table 3

Breakdown of Grades

\begin{tabular}{|c|c|c|c|c|}
\hline \multirow[b]{2}{*}{ Grade } & \multicolumn{2}{|c|}{ Lots } & \multicolumn{2}{|c|}{ Total Head } \\
\hline & $N$ & $\%$ & $N$ & $\%$ \\
\hline $\mathrm{L}$ & 847 & 22.5 & 24,804 & 18.8 \\
\hline LM2 & 15 & 0.4 & 443 & 0.3 \\
\hline M & 2,780 & 74.0 & 104,199 & 79.1 \\
\hline S & 113 & 3.0 & 2,236 & 1.7 \\
\hline $\mathrm{FG}$ & 2 & 0.1 & 34 & 0.0 \\
\hline & & & 131,716 & 100.0 \\
\hline
\end{tabular}

In addition to understanding the grade and breed of cattle that were sold in the state, it is essential to determine the weight classes in which the cattle were sold. By determining the most prevalent weight classes sold it allowed for further analyses to be conducted related to how cattle can efficiently reach the desired market weight, while considering production costs, overhead expenses, and the breakeven point for production. Weight classes for the study were established based on one hundred pound increments and ranged from 400 through 1200 pounds weight classes. The most prominent weight class sold in West Virginia was found to be 700 pound weight cattle with a total of 1,310 lots $(34.8 \%)$ sold. The next closest group was the 600 pound weight cattle with 1,094 lots sold (29.1\%). This analysis determined that most farmers were trying to sell yearling cattle in the 600-799 pound weight range. A common practice is for buyers to want to purchase $400-500$ pound entry level cattle with their goal to add 100 to 400 pounds of gain before they send them back to the market as yearling cattle (see Table 5). 
Table 4

Breakdown of Breeds Sold

\begin{tabular}{|c|c|c|c|c|}
\hline \multirow[b]{2}{*}{ Breeds } & \multicolumn{2}{|c|}{ Lots } & \multicolumn{2}{|c|}{ Total Head } \\
\hline & $N$ & $\%$ & $N$ & $\%$ \\
\hline Black & 1,904 & 50.7 & 77,954 & 59.1 \\
\hline BWF & 850 & 22.6 & 24,859 & 18.9 \\
\hline Charolais & 642 & 17.1 & 19,296 & 14.6 \\
\hline Hereford & 114 & 3.0 & 3,795 & 2.9 \\
\hline Limousin & 62 & 1.6 & 1,068 & 0.8 \\
\hline Mixed Lot & 5 & 0.2 & 337 & 0.3 \\
\hline Red & 1 & 0.0 & 27 & 0.0 \\
\hline Red Cross & 172 & 4.6 & 4,294 & 3.3 \\
\hline Roan & 1 & 0.0 & 18 & 0.0 \\
\hline Simmental & 6 & 0.2 & 165 & 0.1 \\
\hline Smokie & 1 & 0.0 & 12 & 0.0 \\
\hline & & & 131,825 & 100.0 \\
\hline
\end{tabular}


Table 5

Weight Class Breakdown

\begin{tabular}{|c|c|c|c|c|}
\hline \multirow[b]{2}{*}{ Weight Class } & \multicolumn{2}{|c|}{ Lots } & \multicolumn{2}{|c|}{ Total Head } \\
\hline & $N$ & $\%$ & $N$ & $\%$ \\
\hline $400-499$ & 62 & 1.6 & 1,055 & 0.8 \\
\hline $500-599$ & 164 & 4.4 & 3,548 & 2.7 \\
\hline $600-699$ & 1,094 & 29.1 & 41,549 & 31.5 \\
\hline $700-799$ & 1,310 & 34.8 & 49,272 & 37.4 \\
\hline $800-899$ & 827 & 22.0 & 27,621 & 21.0 \\
\hline $900-999$ & 239 & 6.4 & 7,041 & 5.3 \\
\hline 1000-1099 & 56 & 1.5 & 1,569 & 1.2 \\
\hline 1100-1199 & 6 & 0.2 & 158 & 0.1 \\
\hline \multirow[t]{2}{*}{$1200-1299$} & 1 & 0.0 & 12 & 0.0 \\
\hline & & & 131,825 & 100.0 \\
\hline
\end{tabular}

The last portion of the descriptive data determined where the cattle in the state were being sold. The state of West Virginia and the western portion of Maryland were split into regions based on the Adjusted Gross Revenue- Lite (AGR-Lite) pilot program. This particular program split the state into seven regions (see Figure 1). The AGR-Lite regions were used to analyze where the cattle were being sold. It was found that an overwhelming number of the cattle were being sold in region 7, which represents the central portion of West Virginia. This region reported 2,622 lots (71.2\%) of cattle sold (see Table 6). 


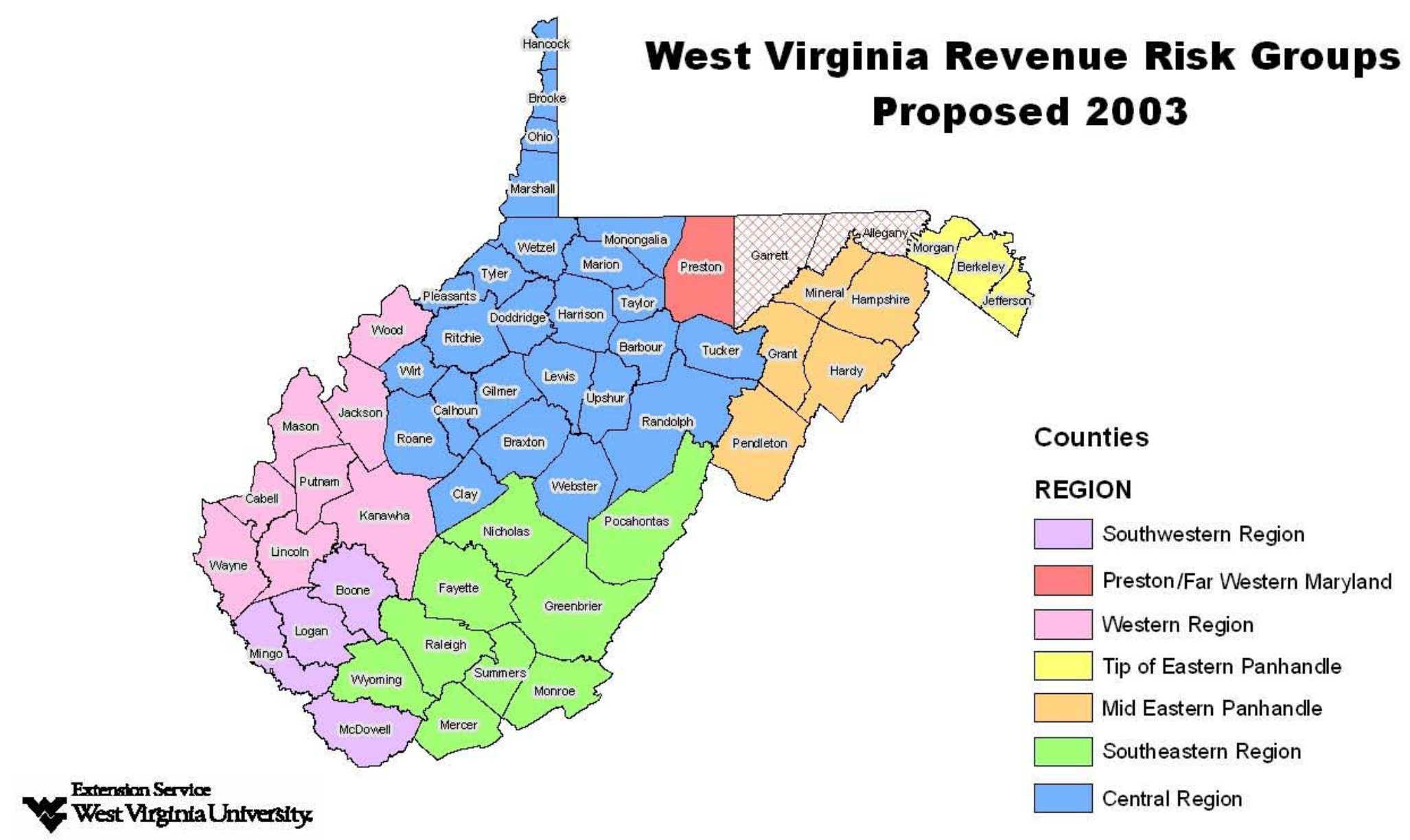

Figure 1: West Virginia Revenue Risk Groups 
Table 6

AGR-Lite Regions Cattle Sold Through

\begin{tabular}{|c|c|c|c|c|}
\hline \multirow[b]{2}{*}{ Region } & \multicolumn{2}{|c|}{ Lots } & \multicolumn{2}{|c|}{ Total Head } \\
\hline & $N$ & $\%$ & $N$ & $\%$ \\
\hline 2 & 30 & 0.8 & 675 & 0.5 \\
\hline 3 & 24 & 0.6 & 749 & 0.6 \\
\hline 5 & 749 & 20.3 & 28,422 & 21.8 \\
\hline 6 & 214 & 5.8 & 7,691 & 5.9 \\
\hline 7 & 2,622 & 71.2 & 89,472 & 68.6 \\
\hline 8 & 46 & 1.2 & 3,382 & 2.6 \\
\hline & & & 130,391 & 100.0 \\
\hline
\end{tabular}

Case Studies

Four West Virginia beef cattle producers were selected for the case study portion of this research. The research analyzed their personal cattle sales and compared their data with the state cattle prices. This comparison provided evidence related to how individual cattle producers compared with the state-wide cattle prices and how they managed their risks to ensure profitability. While the sales receipts and profit margins were quantitative in nature, a qualitative analysis aspect was also incorporated into the case studies. The case study producers were interviewed and information was gathered on the following aspects of their operation:

- How do you find cattle to fill your sale lots?

- How are the cattle raised?

- When are the cattle bought and sold? 
- What turn-out expenses do you have? (Turn-out expenses were described as costs that were association with getting the cattle ready to be turned out to pasture and begin the fattening process.)

- What is your anticipated weight gain?

\section{Population and Instrumentation of the Case Studies}

The population for the case studies was four purposefully selected farmer/ producers. Farmers were selected from across the state of West Virginia based on the following criteria:

- Must sell at least one graded lot of cattle yearly.

- Must have price data for at least seven consecutive years.

- Must be willing to share pricing information and sales receipts with the researcher.

- Individual calf weights must be 600 pounds or greater.

- Lot weights must be 9,000 pounds or greater.

Individual sale receipts were limited to the calculation of profits and used to determine the benefits of a potential price protection option. The study attempted to trace price trends throughout the state of West Virginia as well as trace the individual producer prices to test the potential benefits of a price protection program. The case studies examined product prices and compared the producer prices received and the average corresponding state price to identify years that a price protection option would have assisted the producer.

\section{Case Study 1}

The operation used in case study one was a large cow-calf operation, which owned nearly 200 cows. The majority of the calves were sold in yearling cattle lots. Depending on the number 
of live calves and the ratio of steers to heifers, additional cattle were purchased to complete a load of cattle, which was a minimum of 9,000 pounds. The calves were weaned in the fall of the year, primarily in November, and placed into the stocker operation. If additional calves were needed, they were purchased in March and April and targeted to be sold in July or August.

When the cattle were placed into the stocker operation they were in the weight range of $300-400$ pounds. The cattle were managed in a highly intensive rotational grazing operation and were fed a small supplement of grain, estimated between two to three pounds per head per day. Hay was provided as a supplement during the winter months. The cattle were placed back on pasture as soon as the grass was ready in the spring. The producer used pasture as the main source of weight gain. The producer utilized approved management practices to enhance grass growth. The cattle were pushed by using the additional grass growth and supplemented grain to gain more weight and hit the target weight of 700-899 pounds by the time they were sold in July or August.

The cattle in this operation were on the West Virginia Gold Quality Assurance Program. This program requires for all cattle to be vaccinated and weaned 40 days before sale or in the case of this operation 40 days before they were put into production. The following vaccinations were given: IBR P13, BVD, BRSV, Lepto 5, 7 Way Clostidum and H. Somnus. The cattle were also dewormed and administered grub and lice control. Ultimately, this operation adhered to these guidelines as all of these cattle were sold as lots through the West Virginia Quality Assurance Sales.

The factors of grade, breed, month sold, weight class and sex of the cattle sold were analyzed and compared to the state average. In Case Study 1, it was found that 24 lots (40\%) of cattle sold were M grade and 24 lots (40\%) were Charolais. Of the cattle sold, 38 lots (63.3\%) 
were steer lots with 39 lots $(65.0 \%)$ in the 800-899 weight class. Forty-seven lots $(78.3 \%)$ were sold in the month of August (see Table 7).

Table 7

Descriptive Data for Case Study 1

\begin{tabular}{|c|c|c|}
\hline & $\mathbf{N}$ & $\%$ \\
\hline \multicolumn{3}{|l|}{ Grade } \\
\hline M & 46 & 76.7 \\
\hline $\mathrm{L}$ & 14 & 23.3 \\
\hline \multicolumn{3}{|l|}{ Breed } \\
\hline Black & 19 & 31.7 \\
\hline BWF & 13 & 21.7 \\
\hline Charolais & 24 & 40.0 \\
\hline Red X & 4 & 6.7 \\
\hline \multicolumn{3}{|l|}{ Sex } \\
\hline Steers & 38 & 63.3 \\
\hline Heifers & 22 & 36.7 \\
\hline \multicolumn{3}{|l|}{ Month } \\
\hline July & 13 & 21.7 \\
\hline August & 47 & 78.3 \\
\hline \multicolumn{3}{|l|}{ Weight Class } \\
\hline $700-799$ & 20 & 33.3 \\
\hline $800-899$ & 39 & 65.0 \\
\hline $900-999$ & 1 & 1.7 \\
\hline
\end{tabular}

To analyze the case study data, the lot prices were recorded separately for steers and heifers. The lot sale prices were matched with the corresponding grade, breed and month of sale from the statewide price averages. The differences were calculated by subtracting the individual 
sale price from the state price. A zero or positive number reflected a price at or above the state average price received by the producer. Numbers that were negative reflected a price below the state average for the producer. For Case Study 1, it was found that for most years the producer was at the state average or above on their sale prices.

In the years of 1993, 1995 and 2000 it was determined that steer prices were well below the state sale average. Three lots of steers sold in August of 1993 had a combined below average price of $\$ 20.04$ per hundred weight. In 1995, five lots were sold, two netted an above average combined total of $\$ 6.45$ per hundred weight, however the remaining three lots were sold for a total of $\$ 7.35$ per hundred weight under the average. This data reflected $\$ 0.90$ per hundred weight below average sale on the steers sold. In 2000 , the producer recorded a $\$ 0.55$ per hundred weight negative price on a single steer lot sold (see Table 8).

In 1990, 1993, 1995 and 2000 the Case Study 1 producer was below the state average price for heifer sales. In 1990, two lots of heifers were sold below the state average for a total of $\$ 5.36$ per hundred weight. In 1993, three heifer lots were sold. Two lots were sold at the state average, however the third lot was sold for $\$ 0.25$ under the average. Combined with the prices received on the steers, a total below average level of nearly $\$ 21.00$ per hundred weight was determined. In 1995, two lots of heifers were sold. One lot was at the state average while the second lot was $\$ 2.25$ below the state price. When this below average price is combined with the 1993 prices in the steer market, a total of $\$ 3.15$ under that state average per hundred weight was reported. In 2000, the single heifer lot was sold at $\$ 1.33$ below the average making a net value below the state average of $\$ 1.88$ for the steer and heifer lots (see Table 9). 
Table 8

Case Study 1 Steer Price Comparisons

\begin{tabular}{|c|c|c|c|c|c|c|c|}
\hline Year & Grade & Breed & Weight & Month & $\begin{array}{c}\text { Sale } \\
\text { Price }\end{array}$ & $\begin{array}{l}\text { State } \\
\text { Price }\end{array}$ & Difference \\
\hline 1990 & $\mathrm{M}$ & Charolais & $700-799$ & August & $\$ 84.25$ & $\$ 79.58$ & $\$ 4.67$ \\
\hline 1991 & M & $\operatorname{Red} X$ & 800-899 & August & $\$ 80.60$ & $\$ 80.60$ & $\$ 0.00$ \\
\hline 1991 & $\mathrm{~L}$ & Charolais & 800-899 & August & $\$ 80.60$ & $\$ 80.60$ & $\$ 0.00$ \\
\hline 1991 & $\mathrm{~L}$ & Charolais & $900-999$ & August & $\$ 78.25$ & $\$ 78.25$ & $\$ 0.00$ \\
\hline 1992 & $\mathrm{~L}$ & BWF & $800-899$ & August & $\$ 79.25$ & $\$ 79.25$ & $\$ 0.00$ \\
\hline 1992 & M & BWF & $800-899$ & August & $\$ 79.25$ & $\$ 79.25$ & $\$ 0.00$ \\
\hline 1993 & $\mathrm{~L}$ & Charolais & $800-899$ & August & $\$ 84.35$ & $\$ 100.50$ & $(\$ 16.15)$ \\
\hline 1993 & M & Black & $700-799$ & August & $\$ 84.10$ & $\$ 87.16$ & $(\$ 3.06)$ \\
\hline 1993 & M & BWF & $800-899$ & August & $\$ 84.10$ & $\$ 84.93$ & $(\$ 0.83)$ \\
\hline 1994 & $\mathrm{~L}$ & Charolais & 800-899 & August & $\$ 76.85$ & $\$ 75.68$ & $\$ 1.17$ \\
\hline 1994 & M & Black & $800-899$ & August & $\$ 76.35$ & $\$ 69.17$ & $\$ 7.18$ \\
\hline 1994 & M & BWF & $800-899$ & August & $\$ 76.35$ & $\$ 68.50$ & $\$ 7.85$ \\
\hline 1994 & M & Charolais & $800-899$ & August & $\$ 80.60$ & $\$ 68.17$ & $\$ 12.43$ \\
\hline 1995 & M & Black & $700-799$ & August & $\$ 61.50$ & $\$ 62.97$ & $(\$ 1.47)$ \\
\hline 1995 & M & Black & 800-899 & August & $\$ 68.00$ & $\$ 64.60$ & $\$ 3.40$ \\
\hline 1995 & M & BWF & $700-799$ & August & $\$ 61.50$ & $\$ 63.63$ & $(\$ 2.13)$ \\
\hline 1995 & $\mathrm{M}$ & BWF & 800-899 & August & $\$ 68.00$ & $\$ 64.95$ & $\$ 3.05$ \\
\hline 1995 & M & $\operatorname{Red} X$ & 800-899 & August & $\$ 59.25$ & $\$ 63.00$ & $(\$ 3.75)$ \\
\hline 1996 & $\mathrm{~L}$ & Charolais & 800-899 & July & $\$ 60.75$ & $\$ 60.43$ & $\$ 0.32$ \\
\hline 1996 & M & Black & $700-799$ & July & $\$ 61.75$ & $\$ 61.75$ & $\$ 0.00$ \\
\hline 1996 & $\mathrm{M}$ & BWF & $700-799$ & July & $\$ 61.75$ & $\$ 61.75$ & $\$ 0.00$ \\
\hline 1997 & M & Black & 800-899 & August & $\$ 77.48$ & $\$ 75.76$ & $\$ 1.72$ \\
\hline 1997 & M & BWF & 800-899 & August & $\$ 76.85$ & $\$ 75.01$ & $\$ 1.84$ \\
\hline 1997 & M & Charolais & 800-899 & August & $\$ 80.00$ & $\$ 75.67$ & $\$ 4.33$ \\
\hline 1998 & M & Black & $700-799$ & August & $\$ 70.50$ & $\$ 66.86$ & $\$ 3.64$ \\
\hline 1998 & M & Black & 800-899 & August & $\$ 66.00$ & $\$ 64.72$ & $\$ 1.28$ \\
\hline
\end{tabular}


Table 8 (Continued)

Case Study 1 Steer Price Comparisons

\begin{tabular}{cccccccc}
\hline Year & Grade & Breed & Weight & Month & $\begin{array}{l}\text { Sale } \\
\text { Price }\end{array}$ & $\begin{array}{l}\text { State } \\
\text { Price }\end{array}$ & Difference \\
\hline 1998 & M & BWF & $800-899$ & July & $\$ 68.50$ & $\$ 65.00$ & $\$ 3.50$ \\
1998 & M & Charolais & $800-899$ & July & $\$ 65.75$ & $\$ 64.06$ & $\$ 1.69$ \\
1999 & M & Black & $700-799$ & July & $\$ 77.25$ & $\$ 75.57$ & $\$ 1.68$ \\
1999 & M & BWF & $800-899$ & July & $\$ 76.00$ & $\$ 75.13$ & $\$ 0.87$ \\
1999 & M & Charolais & $700-799$ & July & $\$ 76.00$ & $\$ 75.50$ & $\$ 0.50$ \\
1999 & M & Charolais & $800-899$ & July & $\$ 74.25$ & $\$ 74.25$ & $\$ 0.00$ \\
2000 & M & Black & $800-899$ & August & $\$ 82.75$ & $\$ 83.30$ & $(\$ 0.55)$ \\
\hline
\end{tabular}

The overall income for Case Study 1 was at or above the state average for both steers and heifers. However, there were years when it would have been beneficial to purchase protection options like revenue insurance to safe guard against the times where prices were well below the state average. 
Table 9

Case Study 1 Heifer Price Comparisons

\begin{tabular}{rccrlllr}
\hline Year & Grade & Breed & Weigh & Month & $\begin{array}{c}\text { Sale } \\
\text { Price }\end{array}$ & $\begin{array}{l}\text { State } \\
\text { Price }\end{array}$ & Difference \\
\hline 1990 & L & Charolais & $700-799$ & August & $\$ 81.45$ & $\$ 84.13$ & $(\$ 2.68)$ \\
1990 & M & Charolais & $700-799$ & August & $\$ 81.45$ & $\$ 84.13$ & $(\$ 2.68)$ \\
1991 & L & Charolais & $800-899$ & August & $\$ 78.85$ & $\$ 78.85$ & $\$ 0.00$ \\
1991 & M & Charolais & $800-899$ & August & $\$ 78.85$ & $\$ 78.85$ & $\$ 0.00$ \\
1992 & L & Charolais & $800-899$ & August & $\$ 81.75$ & $\$ 81.75$ & $\$ 0.00$ \\
1992 & M & Charolais & $800-899$ & August & $\$ 86.25$ & $\$ 80.35$ & $\$ 5.90$ \\
1993 & L & Charolais & $800-899$ & August & $\$ 81.25$ & $\$ 81.25$ & $\$ 0.00$ \\
1993 & M & Black & $700-799$ & August & $\$ 84.00$ & $\$ 84.00$ & $\$ 0.00$ \\
1993 & M & BWF & $700-799$ & August & $\$ 84.00$ & $\$ 84.25$ & $(\$ 0.25)$ \\
1994 & L & Charolais & $800-899$ & August & $\$ 75.40$ & $\$ 75.40$ & $\$ 0.00$ \\
1994 & M & Black & $700-799$ & August & $\$ 75.00$ & $\$ 73.50$ & $\$ 1.50$ \\
1994 & M & BWF & $700-799$ & August & $\$ 75.00$ & $\$ 73.50$ & $\$ 1.50$ \\
1994 & M & Charolais & $800-899$ & August & $\$ 75.40$ & $\$ 75.40$ & $\$ 0.00$ \\
1995 & M & Charolais & $800-899$ & August & $\$ 61.50$ & $\$ 61.50$ & $\$ 0.00$ \\
1995 & M & Red X & $800-899$ & August & $\$ 59.25$ & $\$ 61.50$ & $(\$ 2.25)$ \\
1997 & M & Black & $700-799$ & August & $\$ 76.75$ & $\$ 75.11$ & $\$ 1.64$ \\
1997 & M & BWF & $700-799$ & August & $\$ 76.25$ & $\$ 74.31$ & $\$ 1.94$ \\
1998 & M & Black & $700-799$ & August & $\$ 63.75$ & $\$ 63.08$ & $\$ 0.67$ \\
1999 & L & Charolais & $700-799$ & July & $\$ 73.50$ & $\$ 72.50$ & $\$ 1.00$ \\
1999 & M & Black & $700-799$ & July & $\$ 73.25$ & $\$ 71.58$ & $\$ 1.67$ \\
2000 & M & Black & $700-799$ & August & $\$ 80.75$ & $\$ 82.08$ & $(\$ 1.33)$ \\
\hline
\end{tabular}




\section{Case Study 1 Steer Price Comparisons}

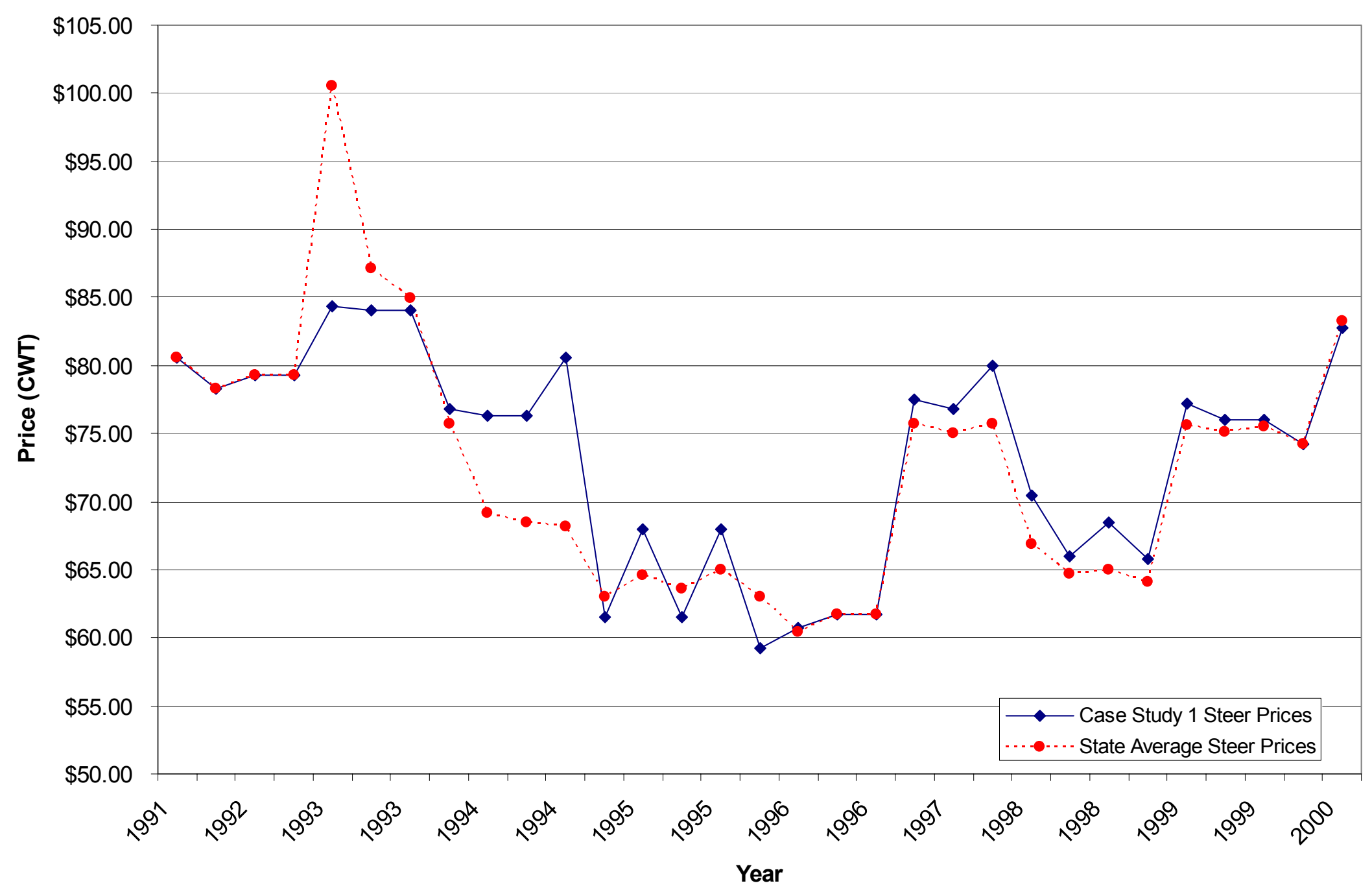

Figure 2: Case Study 1 Steer Price Comparison 


\section{Case Study 1 Heifer Price Comparisons}

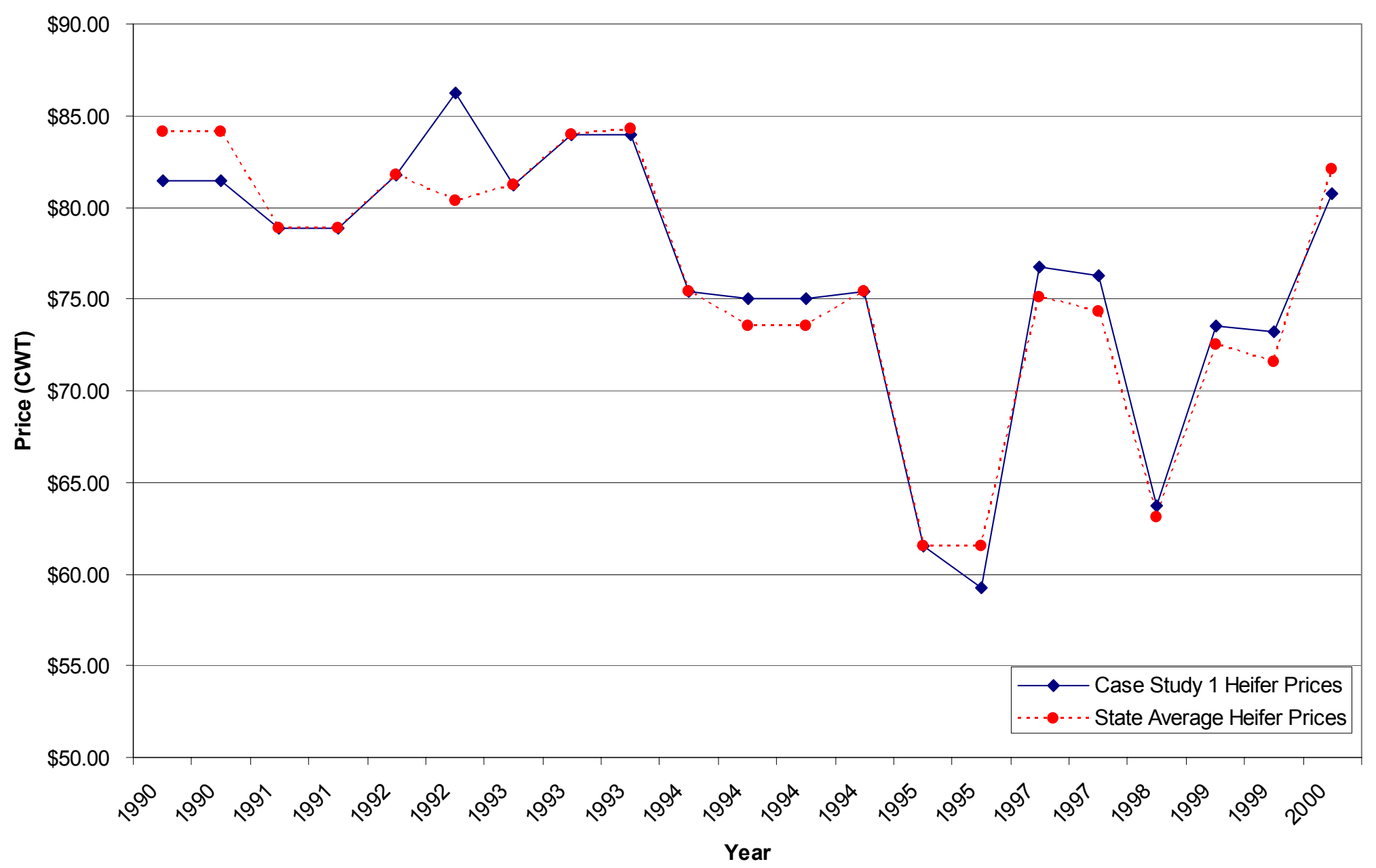

Figure 3: Case Study 1 Heifer Price Comparison 


\section{Case Study 2}

The second case study was a large stocker cattle operation. The producer bought all of the cattle for the operation and two options to distribute the finished product. The first option was to feed the cattle to $700-800$ pounds and ship them on to feedlots where they will be feed to final slaughter weights. The second option was when the producer retained and fed out the cattle and shipped the slaughter weight animals to Iowa Beef Processors (IBP). The cattle purchased by this operation were all lighter weight cattle, between 400-500 pounds and with evident growth potential. The producer strived to select $\mathrm{M}$ grade cattle that had the potential to put on at least 250 pounds of gain by the time they were shipped. The cattle were strictly pasture feed with supplemental hay provided when grass was short. Occasionally grain was supplemented if the cattle need extra weight. While this operation rotated cattle throughout the year, the largest number of cattle were purchased in April and sold in September.

The cattle were on the West Virginia Gold Quality Assurance Program. The vaccinations given were: IBR P13, BVD, BRSV, Lepto 5, 7 Way Clostidum and H. Somnus. The cattle were also dewormed and administered grub and lice control. The vaccination program was administered upon the arrival of the cattle. No cattle were bought for this operation unless they were preconditioned by being weaned and ready to start on pasture or grain to enhance growth and performance.

During the analyses of this operation it was found that 74 lots (96.1\%) were M grade cattle, and 59 lots (76.6\%) were black. Of the cattle sold, 62 lots (80.5\%) were steers and all 77 lots $(100.0 \%)$ were sold in September. The largest segment of the cattle sold were in the 700-799 weight range $(\mathrm{n}=35$ lots, $45.5 \%)$ (see Table 10$)$. 
Table 10

Descriptive Data for Case Study 2

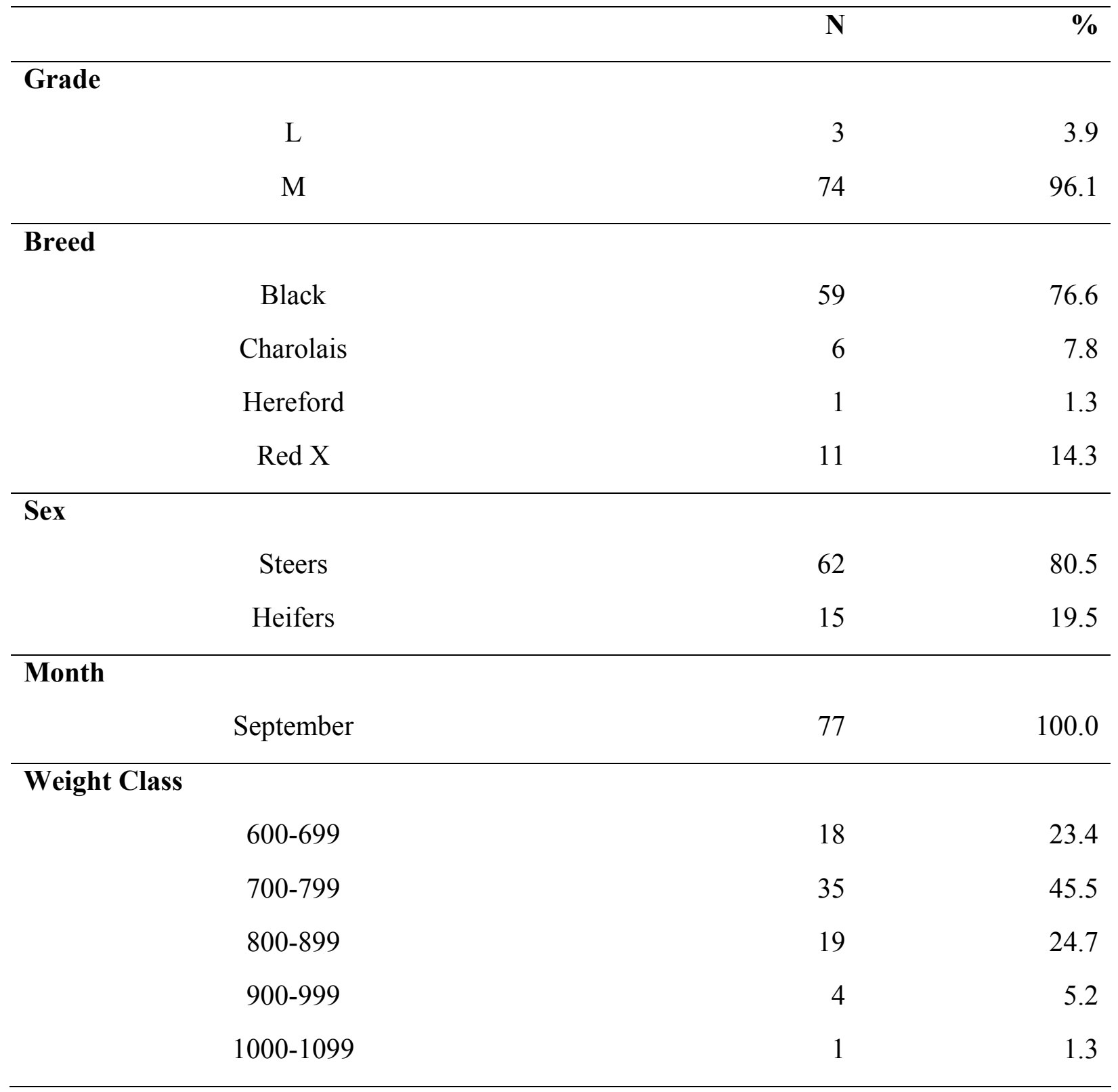

During the analyses of sale records for Case Study 2 several challenging years were identified in regards to a noticeable difference in prices received and average state prices. The years that present themselves as a center of concern were 1997 and 1998. In 1997, four lots of 
steers were sold and all recorded prices were below the state average. The below average prices ranged from $\$ 0.08$ to a high of $\$ 3.75$. The total net difference from the state average for the four lots was $\$ 6.13$. In 1998 , four lots of steers were also sold. All of the lots were sold under the state average for the same type of cattle. The total below average price on the four lots was $\$ 5.00$ per hundred weight. With two consecutive years under the state average, this producer may have benefited from a form of price protection (see Table 11).

Table 11

Case Study 2 Steer Price Comparisons

\begin{tabular}{rccccccr}
\hline Year & Grade & Breed & Weight & Month & $\begin{array}{l}\text { Sale } \\
\text { Price }\end{array}$ & $\begin{array}{l}\text { State } \\
\text { Price }\end{array}$ & Difference \\
\hline 1997 & M & Black & $600-699$ & September & $\$ 74.85$ & $\$ 76.53$ & $(\$ 1.68)$ \\
1997 & M & Black & $700-799$ & September & $\$ 75.17$ & $\$ 75.79$ & $(\$ 0.62)$ \\
1997 & M & Black & $800-899$ & September & $\$ 73.38$ & $\$ 73.46$ & $(\$ 0.08)$ \\
1997 & M & Red X & $800-899$ & September & $\$ 74.00$ & $\$ 77.75$ & $(\$ 3.75)$ \\
1998 & M & Black & $600-699$ & September & $\$ 67.00$ & $\$ 67.00$ & $\$ 0.00$ \\
1998 & M & Black & $700-799$ & September & $\$ 62.63$ & $\$ 64.55$ & $(\$ 1.92)$ \\
1998 & M & Charolais & $600-699$ & September & $\$ 61.00$ & $\$ 62.17$ & $(\$ 1.17)$ \\
1998 & M & Charolais & $800-899$ & September & $\$ 60.31$ & $\$ 61.09$ & $(\$ 0.78)$ \\
1998 & M & Red X & $800-899$ & September & $\$ 61.50$ & $\$ 62.63$ & $(\$ 1.13)$ \\
1999 & L & Charolais & $700-799$ & September & $\$ 75.48$ & $\$ 75.48$ & $\$ 0.00$ \\
1999 & M & Black & $600-699$ & September & $\$ 71.00$ & $\$ 77.92$ & $(\$ 6.92)$ \\
1999 & M & Black & $700-799$ & September & $\$ 76.24$ & $\$ 77.31$ & $(\$ 1.07)$ \\
1999 & M & Black & $900-999$ & September & $\$ 65.00$ & $\$ 65.00$ & $\$ 0.00$ \\
1999 & M & Black & $1000-$ & September & $\$ 67.50$ & $\$ 67.50$ & \\
1999 & & & 1099 & & & & $\$ 0.00$ \\
1999 & M & Hereford & $600-699$ & September & $\$ 67.50$ & $\$ 74.00$ & $(\$ 6.50)$ \\
\hline
\end{tabular}


Table 11 (Continued)

Case Study 2 Steer Price Comparisons

\begin{tabular}{rrrrrrrr}
\hline Year & Grade & Breed & Weight & Month & $\begin{array}{l}\text { Sale } \\
\text { Price }\end{array}$ & $\begin{array}{l}\text { State } \\
\text { Price }\end{array}$ & Difference \\
\hline 1999 & M & Red X & $700-799$ & September & $\$ 71.19$ & $\$ 71.19$ & $\$ 0.00$ \\
1999 & M & Red X & $800-899$ & September & $\$ 73.50$ & $\$ 73.50$ & $\$ 0.00$ \\
2000 & M & Black & $600-699$ & September & $\$ 81.00$ & $\$ 86.67$ & $(\$ 5.67)$ \\
2000 & M & Black & $700-799$ & September & $\$ 83.34$ & $\$ 82.94$ & $\$ 0.40$ \\
2000 & M & Black & $800-899$ & September & $\$ 77.19$ & $\$ 76.64$ & $\$ 0.55$ \\
2001 & M & Black & $600-699$ & September & $\$ 95.69$ & $\$ 92.45$ & $\$ 3.24$ \\
2001 & M & Black & $700-799$ & September & $\$ 84.21$ & $\$ 87.32$ & $(\$ 3.11)$ \\
2001 & M & Black & $800-899$ & September & $\$ 81.92$ & $\$ 79.53$ & $\$ 2.39$ \\
2001 & M & Black & $900-999$ & September & $\$ 80.96$ & $\$ 77.24$ & $\$ 3.72$ \\
2002 & M & Black & $600-699$ & September & $\$ 77.00$ & $\$ 79.38$ & $(\$ 2.38)$ \\
2002 & M & Black & $700-799$ & September & $\$ 75.50$ & $\$ 77.79$ & $(\$ 2.29)$ \\
2002 & M & Black & $800-899$ & September & $\$ 72.50$ & $\$ 73.03$ & $(\$ 0.53)$ \\
2002 & M & Black & $900-999$ & September & $\$ 72.18$ & $\$ 71.22$ & $\$ 0.96$ \\
2002 & M & RedX & $600-699$ & September & $\$ 74.00$ & $\$ 77.00$ & $(\$ 3.00)$ \\
2003 & L & Black & $800-899$ & September & $\$ 74.84$ & $\$ 74.84$ & $\$ 0.00$ \\
2003 & L & Charolais & $800-899$ & September & $\$ 71.21$ & $\$ 71.21$ & $\$ 0.00$ \\
2003 & M & Black & $600-699$ & September & $\$ 94.18$ & $\$ 94.18$ & $\$ 0.00$ \\
2003 & M & Black & $700-799$ & September & $\$ 92.00$ & $\$ 92.00$ & $\$ 0.00$ \\
2003 & M & Black & $800-899$ & September & $\$ 87.46$ & $\$ 87.46$ & $\$ 0.00$ \\
\hline & M & Red X & $700-799$ & September & $\$ 76.05$ & $\$ 76.05$ & $\$ 0.00$ \\
\hline
\end{tabular}

During the analysis of prices received for heifer sales during the same time frame it was determined that 1998 was once again a challenge. This was the only year that heifer prices were below the state average. The loss was $\$ 0.46$ per hundred weight below the state average, 
however, combined with the prices in the steer market during the same time frame this provides an unstable market situation for the producer at hand (see Table 12).

Table 12

Case Study 2 Heifer Price Comparisons

\begin{tabular}{cccccccc}
\hline Year & Grade & Breed & Weigh & Month & $\begin{array}{c}\text { Sale } \\
\text { Price }\end{array}$ & $\begin{array}{c}\text { State } \\
\text { Price }\end{array}$ & Difference \\
\hline 1997 & M & Black & $600-699$ & September & $\$ 73.29$ & $\$ 50.25$ & $\$ 23.04$ \\
1997 & M & Black & $700-799$ & September & $\$ 71.84$ & $\$ 52.63$ & $\$ 19.21$ \\
1998 & M & Black & $700-799$ & September & $\$ 62.00$ & $\$ 62.46$ & $\$ \$ 0.46)$ \\
1999 & M & Black & $700-799$ & September & $\$ 73.50$ & $\$ 71.42$ & $\$ 2.08$ \\
2000 & M & Black & $700-799$ & September & $\$ 77.40$ & $\$ 77.40$ & $\$ 0.00$ \\
\hline
\end{tabular}

With the exception of the two years, 1997 and 1998, the prices received by this producer were at or above the state average. A price protection program would have offered a boost in the prices endured during the two year stretch (see Figures 3 and 4). 


\section{Case Study 2 Steer Price Comparison}

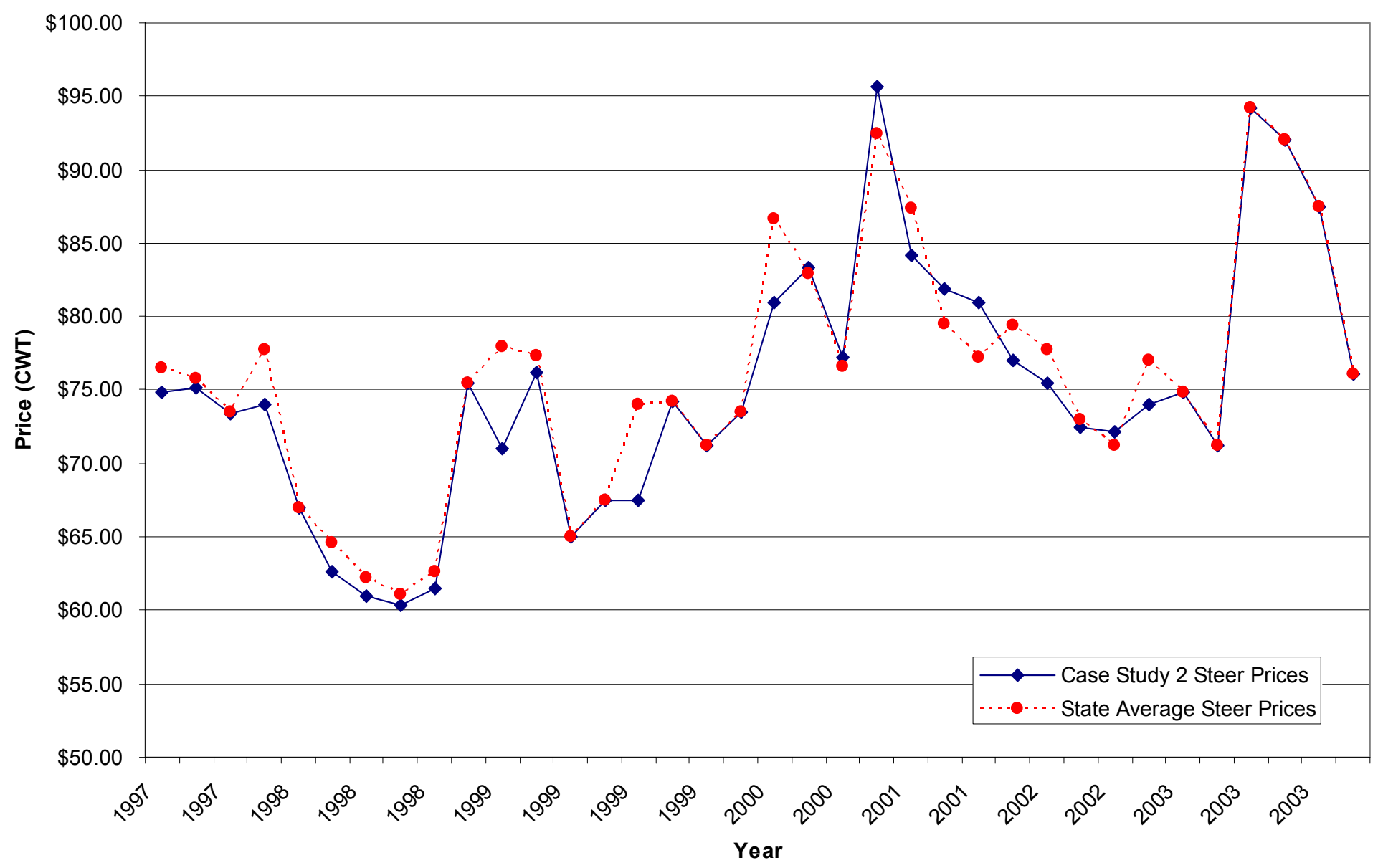

Figure 4: Case Study 2 Steer Price Comparisons 


\section{Case Study 2 Heifer Comparisons}

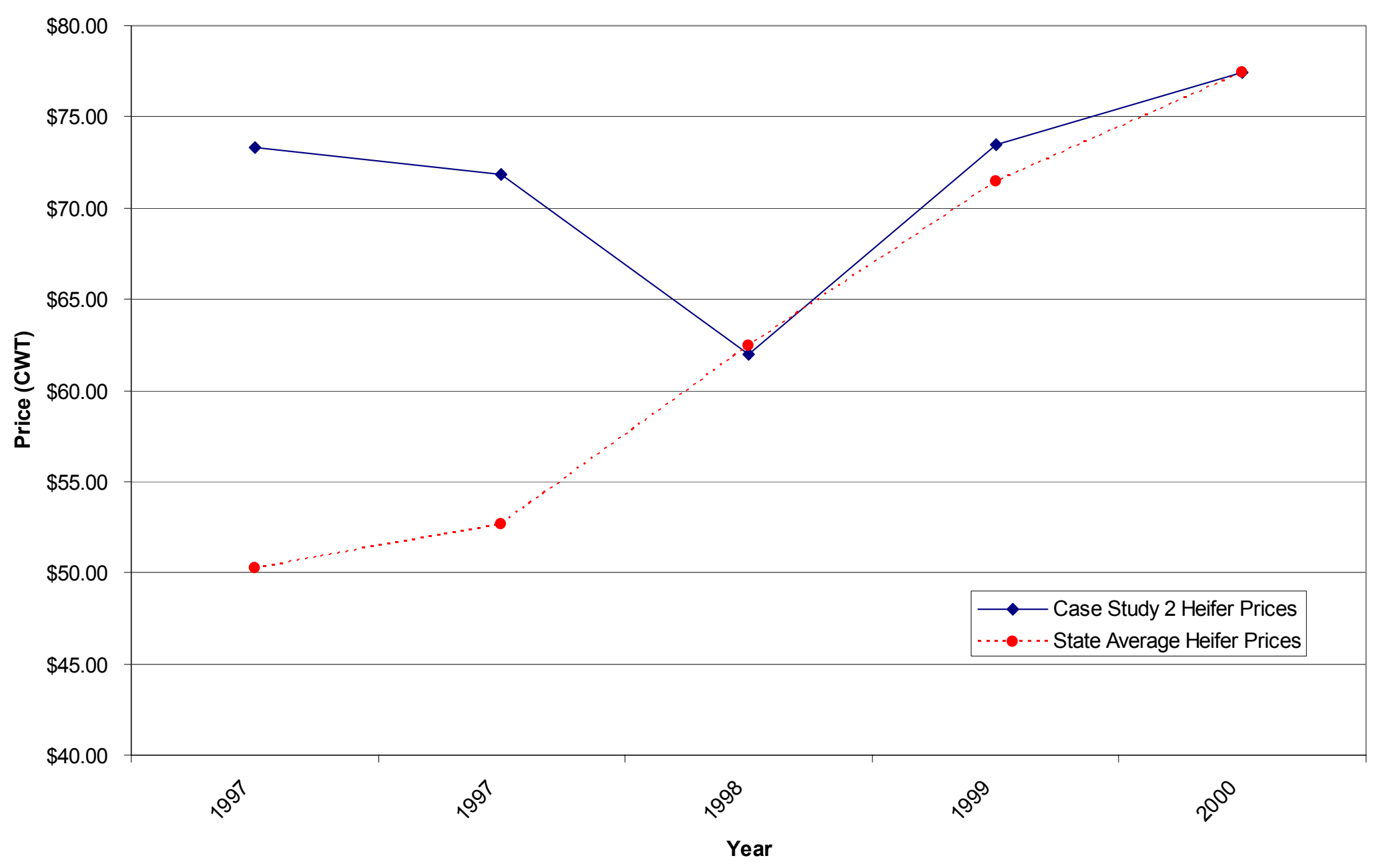

Figure 5: Case Study 2 Heifer Price Comparisons 


\section{Case Study 3}

Case study three was a relatively small self-sufficient operation. The operation maintained 100 cows and all cattle shipped and sold in lots were produced on the farm. All of the cattle were black and $\mathrm{M}$ grade. The operation used pasture as the main source of feed for weight gain on their cattle. The cattle were supplemented with hay in the winter months.

The major difference in this operation was that the cows were bred at different times in the season so that a constant sale flow was provided for the operation. The cattle were raised to a weight range between $600-899$ pounds. Cattle were marketed at various times throughout the year to local auction markets based on their weight and readiness to enter into feedlot production.

The cattle in this operation were on the West Virginia Gold Quality Assurance Program. The vaccinations given were: IBR P13, BVD, BRSV, Lepto 5, 7 Way Clostidum and H. Somnus. The cattle were also dewormed and administered grub and lice control.

During the analyses of the descriptive data for this case study, it was found that all 15 lots $(100.0 \%)$ were black, $\mathrm{M}$ grade, steer cattle. Heifers were used as replacement animals to maintain production. The largest percentage of the steers (26.7\%) was sold in April (see Table $13)$.

During price comparisons for steer lots sold by this operation it was identified that for the majority of the sales were at or above the state average. The only year prices were below the average was 2000 . One lot was sold at $\$ 0.30$ below the state average. This was not a significant loss and may not justify the cost of purchasing a price protection option. The other lot that was below the state average was one of two steer lots sold during the fall of 2002. The lot sold for $\$ 1.75$ under the state average, but the other lot sold for $\$ 1.97$ above the average, ultimately 
offsetting the difference. (see Table 14) Based on the pricing it could be determined that this operation may not be benefited by purchasing pricing options (see Chart 5).

Table 13

Descriptive Data for Case Study 3

\begin{tabular}{|c|c|c|}
\hline & $\mathbf{N}$ & $\%$ \\
\hline \multicolumn{3}{|l|}{ Grade } \\
\hline M & 15 & 100.0 \\
\hline \multicolumn{3}{|l|}{ Breed } \\
\hline Black & 15 & 100.0 \\
\hline \multicolumn{3}{|l|}{ Sex } \\
\hline Steers & 15 & 100.0 \\
\hline \multicolumn{3}{|l|}{ Month } \\
\hline March & 2 & 13.3 \\
\hline April & 4 & 26.7 \\
\hline June & 1 & 6.7 \\
\hline August & 2 & 13.3 \\
\hline September & 2 & 20.0 \\
\hline October & 3 & 20.0 \\
\hline \multicolumn{3}{|l|}{ Weight Class } \\
\hline $600-699$ & 4 & 26.7 \\
\hline $700-799$ & 3 & 20.0 \\
\hline 800-899 & 5 & 33.3 \\
\hline $900-999$ & 2 & 13.3 \\
\hline
\end{tabular}


Table 14

Case Study 3 Steer Price Comparisons

\begin{tabular}{lccccccr}
\hline Year & Grade & Breed & Weight & Month & $\begin{array}{c}\text { Sale } \\
\text { Price }\end{array}$ & $\begin{array}{l}\text { State } \\
\text { Price }\end{array}$ & Difference \\
\hline 1997 & M & Black & $900-999$ & September & $\$ 73.00$ & $\$ 69.93$ & $\$ 3.07$ \\
1998 & M & Black & $900-999$ & September & $\$ 63.00$ & $\$ 60.50$ & $\$ 2.50$ \\
1999 & M & Black & $800-899$ & August & $\$ 75.00$ & $\$ 74.07$ & $\$ 0.93$ \\
2000 & M & Black & $800-899$ & August & $\$ 83.00$ & $\$ 83.30$ & $(\$ 0.30)$ \\
2001 & M & Black & $600-699$ & April & $\$ 101.00$ & $\$ 101.00$ & $\$ 0.00$ \\
2001 & M & Black & $700-799$ & April & $\$ 84.00$ & $\$ 84.00$ & $\$ 0.00$ \\
2002 & M & Black & $800-899$ & September & $\$ 75.00$ & $\$ 73.03$ & $\$ 1.97$ \\
2002 & M & Black & $800-899$ & October & $\$ 73.00$ & $\$ 74.75$ & $(\$ 1.75)$ \\
2003 & M & Black & $600-699$ & April & $\$ 88.00$ & $\$ 88.00$ & $\$ 0.00$ \\
2003 & M & Black & $700-799$ & April & $\$ 87.00$ & $\$ 87.00$ & $\$ 0.00$ \\
2003 & M & Black & $800-899$ & April & $\$ 70.00$ & $\$ 70.00$ & $\$ 0.00$ \\
\hline
\end{tabular}


Case Study 3 Price Comparison

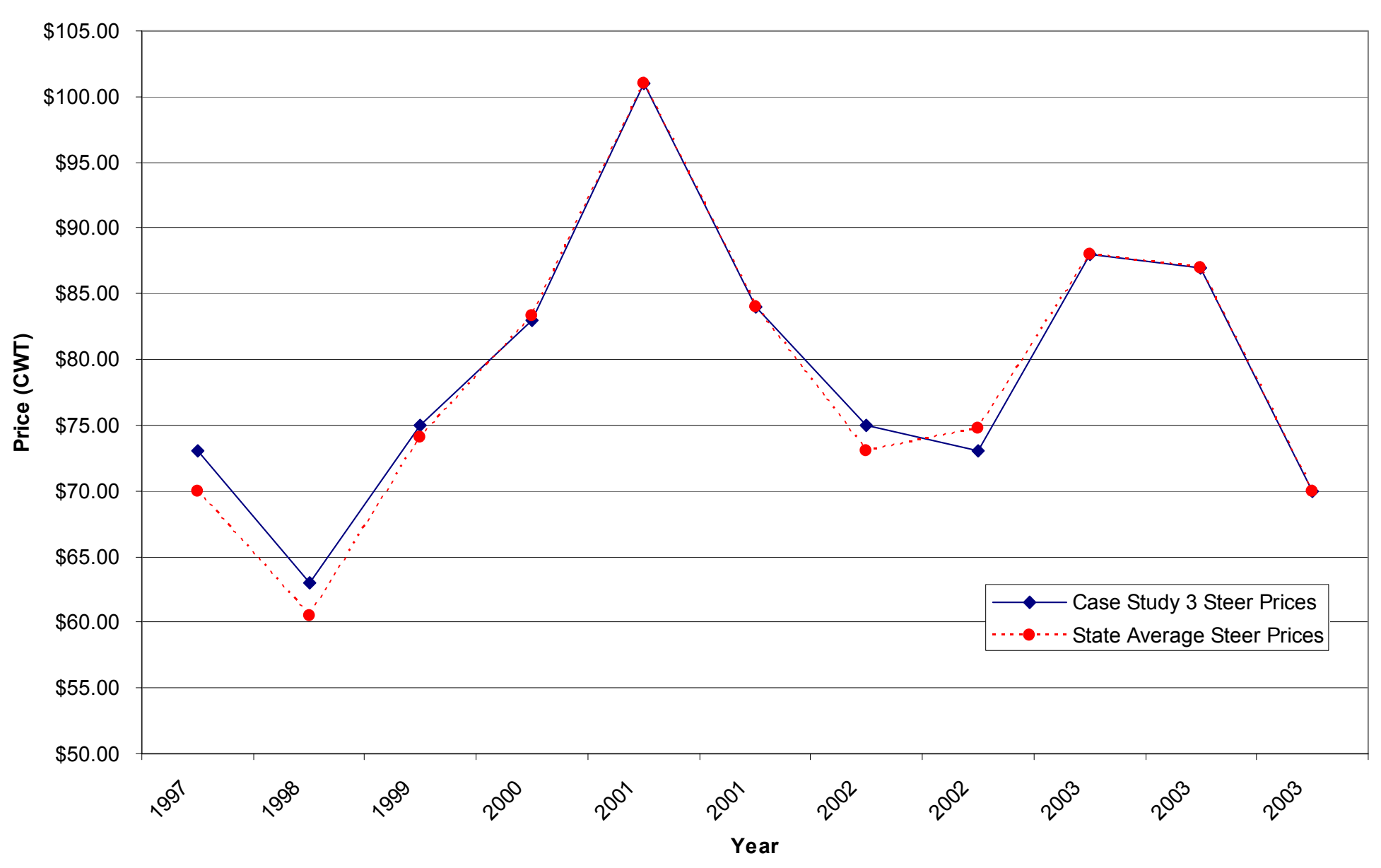

Figure 6: Case Study 3 Price Comparison 


\section{Case Study 4}

The final case study consisted of a stocker operation that bought all of their cattle. This operation purchased cattle from local auction markets across the state of West Virginia. The cattle were purchased at approximately 500-600 pounds and were expected to gain at least 100 pounds before they were sold. The cattle were purchased in the spring of the year and were usually marketed in July or August.

The cattle were $\mathrm{M}$ grade. The breed of the cattle was not as important as the grade for this operation. The cattle were purchased from weekly sales and prices were usually at the average price for the week or slightly below. The cattle were vaccinated using the West Virginia Gold vaccination program. All of these cattle were marketed through the West Virginia Quality Assurance Board Sales.

The largest portion $(n=64$ lots, $85.3 \%)$ of the cattle in this study were M grades. The cattle were primarily Charolais $(n=26$ lots, $34.7 \%)$ or black $(n=25$ lots, $33.3 \%)$. The majority of the lots sold were steers $(n=51$ lots, $68.0 \%)$. Sixty-one lots $(81.3 \%)$ were sold in the month of August and the most commonly marketed weight class was cattle weighing 700-799 pounds (n $=44$ lots, $58.7 \%)($ see Table 15$)$.

Analysis of the pricing data found that in 1996 all four lots sold below the state average. The combined prices below the average for the group was $\$ 8.28$, representing the largest negative difference recorded in the case studies. In 1996, price options would represent an opportunity for covering losses of revenue. The only other below average prices recorded in this case study occurred in 1995. Those losses were smaller in nature and were virtually off-set by lots that sold in the same year that made a profit (see Table 16). 
Table 15

Descriptive Data for Case Study 4

\begin{tabular}{|c|c|c|}
\hline & $\mathbf{N}$ & $\%$ \\
\hline \multicolumn{3}{|l|}{ Grade } \\
\hline $\mathrm{L}$ & 11 & 14.7 \\
\hline M & 64 & 85.3 \\
\hline \multicolumn{3}{|l|}{ Breed } \\
\hline Black & 25 & 33.3 \\
\hline BWF & 17 & 22.7 \\
\hline Charolais & 26 & 34.7 \\
\hline $\operatorname{Red} X$ & 7 & 9.3 \\
\hline \multicolumn{3}{|l|}{ Sex } \\
\hline Steers & 51 & 68.0 \\
\hline Heifers & 24 & 32.0 \\
\hline \multicolumn{3}{|l|}{ Month } \\
\hline July & 14 & 18.7 \\
\hline August & 61 & 81.3 \\
\hline \multicolumn{3}{|l|}{ Weight Class } \\
\hline $600-699$ & 10 & 13.3 \\
\hline $700-799$ & 44 & 58.7 \\
\hline 800-899 & 21 & 28.0 \\
\hline
\end{tabular}


Table 16

Case Study 4 Steer Price Comparisons

\begin{tabular}{|c|c|c|c|c|c|c|c|}
\hline Year & Grade & Breed & Weight & Month & $\begin{array}{c}\text { Sale } \\
\text { Price }\end{array}$ & $\begin{array}{l}\text { State } \\
\text { Price }\end{array}$ & Difference \\
\hline 1990 & $\mathrm{~L}$ & Charolais & $800-899$ & August & $\$ 82.70$ & $\$ 82.70$ & $\$ 0.00$ \\
\hline 1990 & M & Black & 800-899 & August & $\$ 83.40$ & $\$ 83.40$ & $\$ 0.00$ \\
\hline 1990 & M & Charolais & 800-899 & August & $\$ 82.70$ & $\$ 82.70$ & $\$ 0.00$ \\
\hline 1991 & M & Black & 800-899 & August & $\$ 84.00$ & $\$ 81.50$ & $\$ 2.50$ \\
\hline 1991 & M & BWF & $800-899$ & August & $\$ 84.00$ & $\$ 84.00$ & $\$ 0.00$ \\
\hline 1991 & M & Charolais & $700-799$ & August & $\$ 87.50$ & $\$ 87.50$ & $\$ 0.00$ \\
\hline 1992 & M & Black & 800-899 & August & $\$ 83.50$ & $\$ 83.50$ & $\$ 0.00$ \\
\hline 1992 & M & Charolais & $600-699$ & August & $\$ 86.50$ & $\$ 86.50$ & $\$ 0.00$ \\
\hline 1992 & M & Red X & $600-699$ & August & $\$ 86.50$ & $\$ 86.50$ & $\$ 0.00$ \\
\hline 1995 & M & Black & $700-799$ & August & $\$ 63.13$ & $\$ 62.97$ & $\$ 0.16$ \\
\hline 1995 & M & Black & 800-899 & August & $\$ 64.25$ & $\$ 63.75$ & $\$ 0.50$ \\
\hline 1995 & M & BWF & $700-799$ & August & $\$ 63.13$ & $\$ 63.63$ & $(\$ 0.50)$ \\
\hline 1995 & M & BWF & $800-899$ & August & $\$ 64.25$ & $\$ 64.95$ & $(\$ 0.70)$ \\
\hline 1995 & M & Charolais & $700-799$ & August & $\$ 63.25$ & $\$ 61.25$ & $\$ 2.00$ \\
\hline 1995 & M & Charolais & $800-899$ & August & $\$ 63.80$ & $\$ 59.63$ & $\$ 4.17$ \\
\hline 1995 & M & $\operatorname{Red} X$ & $800-899$ & August & $\$ 63.50$ & $\$ 63.00$ & $\$ 0.50$ \\
\hline 1996 & $\mathrm{~L}$ & Charolais & $800-899$ & August & $\$ 60.10$ & $\$ 62.00$ & $(\$ 1.90)$ \\
\hline 1996 & M & Black & 800-899 & August & $\$ 60.85$ & $\$ 62.66$ & $(\$ 1.81)$ \\
\hline 1996 & M & BWF & 800-899 & August & $\$ 60.85$ & $\$ 62.71$ & $(\$ 1.86)$ \\
\hline 1996 & M & Charolais & 800-899 & August & $\$ 60.10$ & $\$ 62.81$ & $(\$ 2.71)$ \\
\hline 1997 & $\mathrm{~L}$ & Charolais & $700-799$ & August & $\$ 81.60$ & $\$ 76.20$ & $\$ 5.40$ \\
\hline 1997 & M & Black & $700-799$ & August & $\$ 81.78$ & $\$ 79.63$ & $\$ 2.15$ \\
\hline 1997 & M & Black & 800-899 & August & $\$ 76.00$ & $\$ 75.76$ & $\$ 0.24$ \\
\hline 1997 & M & BWF & $700-799$ & August & $\$ 81.78$ & $\$ 80.87$ & $\$ 0.91$ \\
\hline
\end{tabular}


Table 16 (Continued)

Case Study 4 Steer Price Comparisons

\begin{tabular}{cccccccc}
\hline Year & Grade & Breed & Weight & Month & $\begin{array}{c}\text { Sale } \\
\text { Price }\end{array}$ & $\begin{array}{l}\text { State } \\
\text { Price }\end{array}$ & Difference \\
\hline 1997 & M & Charolais & $700-799$ & August & $\$ 80.93$ & $\$ 78.86$ & $\$ 2.07$ \\
1997 & M & Red X & $700-799$ & August & $\$ 80.25$ & $\$ 78.67$ & $\$ 1.58$ \\
1998 & L & Charolais & $700-799$ & July & $\$ 68.50$ & $\$ 68.50$ & $\$ 0.00$ \\
1998 & M & Black & $700-799$ & July & $\$ 68.50$ & $\$ 66.50$ & $\$ 2.00$ \\
1998 & M & Black & $700-799$ & August & $\$ 68.68$ & $\$ 66.86$ & $\$ 1.82$ \\
1998 & M & Black & $800-899$ & August & $\$ 66.13$ & $\$ 64.72$ & $\$ 1.41$ \\
1998 & M & BWF & $700-799$ & July & $\$ 68.50$ & $\$ 66.50$ & $\$ 2.00$ \\
1998 & M & BWF & $800-899$ & August & $\$ 68.68$ & $\$ 65.00$ & $\$ 3.68$ \\
1998 & M & Charolais & $700-799$ & July & $\$ 68.50$ & $\$ 67.75$ & $\$ 0.75$ \\
1998 & M & Red X & $700-799$ & August & $\$ 68.50$ & $\$ 66.31$ & $\$ 2.19$ \\
1999 & M & Black & $700-799$ & July & $\$ 77.50$ & $\$ 75.57$ & $\$ 1.93$ \\
1999 & M & Black & $800-899$ & July & $\$ 76.00$ & $\$ 71.79$ & $\$ 4.21$ \\
1999 & M & BWF & $700-799$ & July & $\$ 77.50$ & $\$ 75.30$ & $\$ 2.20$ \\
1999 & M & Charolais & $700-799$ & July & $\$ 76.50$ & $\$ 75.50$ & $\$ 1.00$ \\
\hline
\end{tabular}

Heifer sales for Case Study 4 reported very small losses. During the time frame studied only three lots were identified as being sold below the state average. In 1993 and 1999 the losses recorded were offset by positive selling lots. In 2000, there was a significant loss reported on a single lot sold at $\$ 1.45$ below the state average (see Table 17).

The overall findings for this operation revealed that the majority of the lots sold were at or above the state average. The entire price tracking can be found in Figure 6 for steers and Figure 7 for heifers. 
Table 17

Case Study 4 Heifer Price Comparisons

\begin{tabular}{|c|c|c|c|c|c|c|c|}
\hline Year & Grade & Breed & Weigh & Month & $\begin{array}{c}\text { Sale } \\
\text { Price }\end{array}$ & $\begin{array}{l}\text { State } \\
\text { Price }\end{array}$ & Difference \\
\hline 1990 & $\mathrm{~L}$ & Charolais & $700-799$ & August & $\$ 86.80$ & $\$ 84.13$ & $\$ 2.67$ \\
\hline 1990 & $\mathrm{M}$ & Charolais & 700-799 & August & $\$ 86.80$ & $\$ 84.13$ & $\$ 2.67$ \\
\hline 1992 & $\mathrm{~L}$ & Charolais & 700-799 & August & $\$ 80.35$ & $\$ 80.35$ & $\$ 0.00$ \\
\hline 1992 & $\mathrm{~L}$ & $\operatorname{Red} X$ & $700-799$ & August & $\$ 80.35$ & $\$ 80.35$ & $\$ 0.00$ \\
\hline 1992 & $\mathrm{M}$ & BWF & 700-799 & August & $\$ 80.35$ & $\$ 80.35$ & $\$ 0.00$ \\
\hline 1992 & M & Charolais & 700-799 & August & $\$ 80.35$ & $\$ 80.35$ & $\$ 0.00$ \\
\hline 1993 & $\mathrm{~L}$ & Charolais & $600-699$ & August & $\$ 83.85$ & $\$ 83.96$ & $(\$ 0.11)$ \\
\hline 1993 & $\mathrm{~L}$ & $\operatorname{Red} X$ & $600-699$ & August & $\$ 83.85$ & $\$ 83.85$ & $\$ 0.00$ \\
\hline 1993 & $\mathrm{M}$ & Charolais & $600-699$ & August & $\$ 83.85$ & $\$ 83.03$ & $\$ 0.82$ \\
\hline 1994 & $\mathrm{~L}$ & Black & $700-799$ & August & $\$ 76.00$ & $\$ 76.00$ & $\$ 0.00$ \\
\hline 1994 & $\mathrm{~L}$ & Charolais & 700-799 & August & $\$ 76.00$ & $\$ 72.92$ & $\$ 3.08$ \\
\hline 1994 & M & Black & $600-699$ & August & $\$ 75.60$ & $\$ 73.93$ & $\$ 1.67$ \\
\hline 1994 & M & $\mathrm{BWF}$ & $600-699$ & August & $\$ 75.60$ & $\$ 73.68$ & $\$ 1.92$ \\
\hline 1994 & $\mathrm{M}$ & Charolais & 700-799 & August & $\$ 76.00$ & $\$ 74.00$ & $\$ 2.00$ \\
\hline 1994 & M & $\operatorname{Red} X$ & $700-799$ & August & $\$ 76.00$ & $\$ 74.00$ & $\$ 2.00$ \\
\hline 1997 & M & Black & $600-699$ & August & $\$ 74.10$ & $\$ 73.89$ & $\$ 0.21$ \\
\hline 1997 & $\mathrm{M}$ & Charolais & 700-799 & August & $\$ 77.10$ & $\$ 74.05$ & $\$ 3.05$ \\
\hline 1998 & M & Black & $600-699$ & August & $\$ 65.50$ & $\$ 64.00$ & $\$ 1.50$ \\
\hline 1999 & $\mathrm{M}$ & Black & $600-699$ & July & $\$ 73.50$ & $\$ 74.13$ & $(\$ 0.63)$ \\
\hline 1999 & $\mathrm{M}$ & Charolais & 700-799 & July & $\$ 73.00$ & $\$ 73.00$ & $\$ 0.00$ \\
\hline 2000 & $\mathrm{M}$ & Black & 700-799 & August & $\$ 83.75$ & $\$ 82.08$ & $\$ 1.67$ \\
\hline 2000 & M & BWF & 700-799 & August & $\$ 82.50$ & $\$ 81.95$ & $\$ 0.55$ \\
\hline 2000 & $\mathrm{M}$ & Charolais & $700-799$ & August & $\$ 81.75$ & $\$ 83.20$ & $(\$ 1.45)$ \\
\hline
\end{tabular}




\section{Case Study 4 Steer Comparisons}

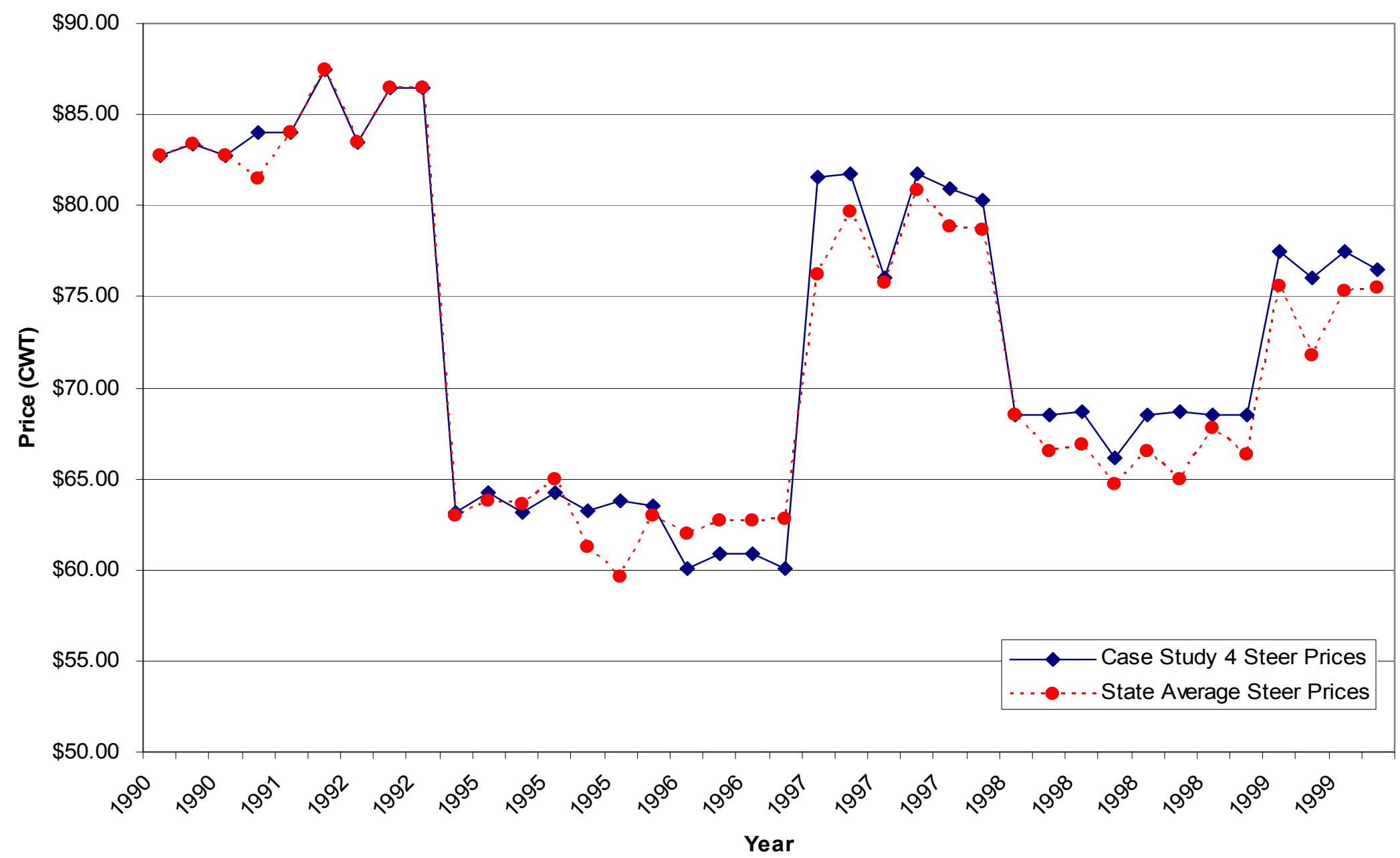

Figure 7: Case Study 4 Steer Comparisons 


\section{Case Study 4 Heifer Comparisons}

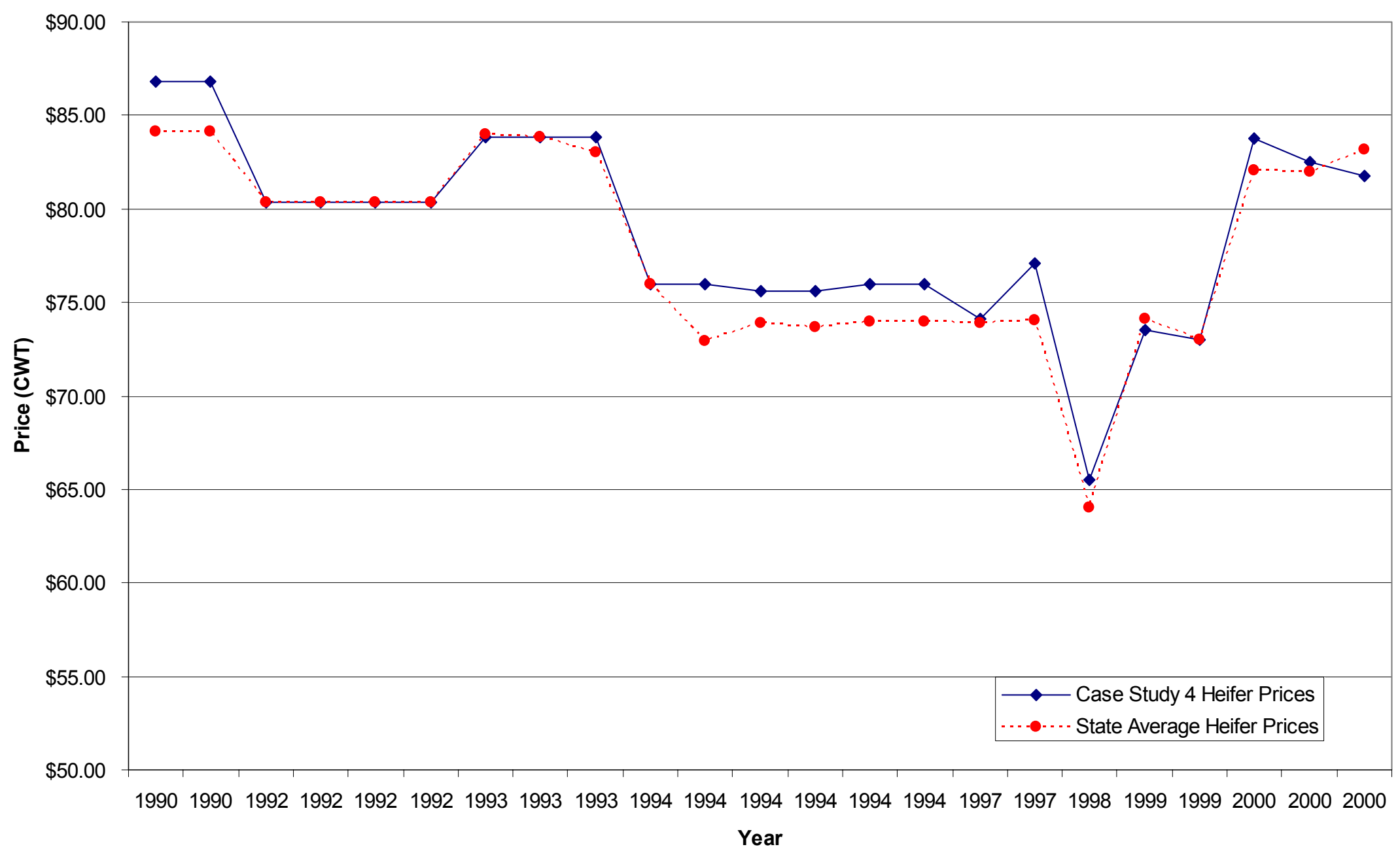

Figure 8: Case Study 4 Heifer Comparisons 


\section{State Price Analysis}

The third component of this study was to analyze the state cattle prices and determine the cost to enter the market and establish the best weight and time to sell the cattle. In order to calculate the price comparison a cross section of the data were analyzed. For this sample Black M grade cattle were used. It was estimated the cattle were purchased in April and sold in August.

The beginning point, 1994, for the example was 400 to 500 pound cattle. Cost included $\$ 12.00$ per head for vaccination, $\$ 7.00$ per head for pasture, $\$ 0.96$ per hundred weight for insurance, a hauling cost of $\$ 6.00$ a head and an interest rate of $8 \%$. The overhead cost was calculated to be $\$ 29.32$ for the 450 pound cattle and $\$ 30.28$ for the 550 pound cattle (see Table $18)$.

The initial buying price and the overhead costs were added together to give the turn-out value or investment in the cattle. Three scenarios were calculated to determine; the price and value of the cattle if they gained $200 \mathrm{lbs}$, if they gained $300 \mathrm{lbs}$, and if they gained $400 \mathrm{lbs}$. These calculations allowed for prices to be studied and to test if there was a trend on which weight class cattle sold best and at what ending weight would allow for the largest profit margin. Problems were encountered in the $200 \mathrm{lbs}$. gain range, which made the cattle $650-750$ pounds when sold. Based on average prices for the years 1994, 1995 and 1998, losses were encountered. This was the only scenario where losses were recorded in the price analysis. The loss margins ranged from $\$ 7.19$ to a high of $\$ 81.03$. These losses represented years that price protections could have been used to benefit the producers across the state. This also identified a target weight where there was the most risk in buying and selling cattle to make a profit (see Table 19). The entire state data set analyses can be found in Appendix A. Individual producers can calculate their own personal risks based on the grade and breed of cattle using the information provided. 
Table 18

Costs to Turn-Out Cattle

\begin{tabular}{|c|c|c|c|c|c|c|c|}
\hline & & & Entry & & Entry & Turn Out & Turn Out \\
\hline Date & Grade & Color & Weight & Price & Price & Costs & Value \\
\hline \multirow[t]{2}{*}{1994} & $\mathrm{M}$ & Black & 450 & $\$ 110.50$ & $\$ 497.25$ & $\$ 29.32$ & $\$ 526.57$ \\
\hline & $\mathrm{M}$ & Black & 550 & $\$ 82.88$ & $\$ 455.84$ & $\$ 30.28$ & $\$ 486.12$ \\
\hline \multirow[t]{2}{*}{1995} & M & Black & 450 & $\$ 85.00$ & $\$ 382.50$ & $\$ 29.32$ & $\$ 411.82$ \\
\hline & M & Black & 550 & $\$ 83.00$ & $\$ 456.50$ & $\$ 30.28$ & $\$ 486.78$ \\
\hline 1996 & M & Black & 550 & $\$ 57.50$ & $\$ 316.25$ & $\$ 30.28$ & $\$ 346.53$ \\
\hline \multirow[t]{2}{*}{1997} & M & Black & 450 & $\$ 81.00$ & $\$ 364.50$ & $\$ 29.32$ & $\$ 393.82$ \\
\hline & M & Black & 550 & $\$ 89.25$ & $\$ 490.88$ & $\$ 30.28$ & $\$ 521.16$ \\
\hline \multirow[t]{2}{*}{1998} & M & Black & 450 & $\$ 103.00$ & $\$ 463.50$ & $\$ 29.32$ & $\$ 492.82$ \\
\hline & M & Black & 550 & $\$ 97.25$ & $\$ 534.88$ & $\$ 30.28$ & $\$ 565.16$ \\
\hline \multirow[t]{2}{*}{1999} & M & Black & 450 & $\$ 94.00$ & $\$ 423.00$ & $\$ 29.32$ & $\$ 452.32$ \\
\hline & M & Black & 550 & $\$ 86.06$ & $\$ 473.33$ & $\$ 30.28$ & $\$ 503.61$ \\
\hline \multirow[t]{2}{*}{2000} & M & Black & 450 & $\$ 111.50$ & $\$ 501.75$ & $\$ 29.32$ & $\$ 531.07$ \\
\hline & M & Black & 550 & $\$ 104.50$ & $\$ 574.75$ & $\$ 30.28$ & $\$ 605.03$ \\
\hline
\end{tabular}


Table 19

Estimated Weight and Price Sales Comparison

\begin{tabular}{|c|c|c|c|c|c|c|c|c|c|c|c|c|c|c|}
\hline 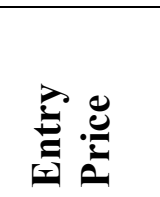 & 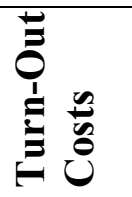 & 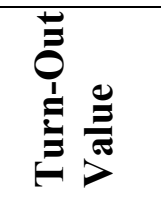 & త్రి & 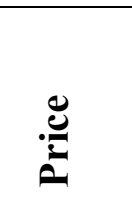 & $\frac{\mathscr{E}}{\stackrel{\Xi}{\sigma}}$ & $\underbrace{\bar{d}}_{\overline{0}}$ & 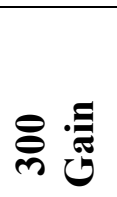 & $\frac{\ddot{U}}{=}$ & 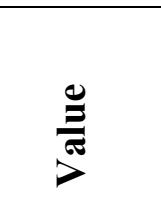 & 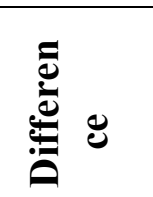 & 导 & 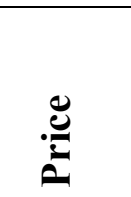 & $\stackrel{\mathscr{V}}{\stackrel{\Xi}{\sigma}}$ & 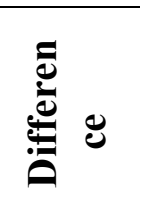 \\
\hline$\$ 497.25$ & $\$ 29.32$ & $\$ 526.57$ & 650 & $\$ 71.92$ & $\$ 467.48$ & $(\$ 59.09)$ & 750 & $\$ 72.91$ & $\$ 546.83$ & $\$ 20.26$ & 850 & $\$ 69.17$ & $\$ 587.95$ & $\$ 61.38$ \\
\hline$\$ 455.84$ & $\$ 30.28$ & $\$ 486.12$ & 750 & $\$ 72.91$ & $\$ 546.83$ & $\$ 60.71$ & 850 & $\$ 69.17$ & $\$ 587.95$ & $\$ 101.83$ & 950 & $\$ 66.75$ & $\$ 634.13$ & $\$ 148.01$ \\
\hline$\$ 382.50$ & $\$ 29.32$ & $\$ 411.82$ & 650 & $\$ 62.25$ & $\$ 404.63$ & $(\$ 7.19)$ & 750 & $\$ 62.25$ & $\$ 466.88$ & $\$ 55.06$ & 850 & $\$ 63.50$ & $\$ 539.75$ & $\$ 127.93$ \\
\hline$\$ 456.50$ & $\$ 30.28$ & $\$ 486.78$ & 750 & $\$ 62.25$ & $\$ 466.88$ & $(\$ 19.91)$ & 850 & $\$ 63.50$ & $\$ 539.75$ & $\$ 52.97$ & 950 & $\$ 60.75$ & $\$ 577.13$ & $\$ 90.35$ \\
\hline$\$ 316.25$ & $\$ 30.28$ & $\$ 346.53$ & 750 & $\$ 62.06$ & $\$ 465.45$ & $\$ 118.92$ & 850 & $\$ 60.75$ & $\$ 516.38$ & $\$ 169.85$ & 950 & $\$ 57.00$ & $\$ 541.50$ & $\$ 194.97$ \\
\hline$\$ 364.50$ & $\$ 29.32$ & $\$ 393.82$ & 650 & $\$ 76.53$ & $\$ 497.45$ & $\$ 103.63$ & 750 & $\$ 75.79$ & $\$ 568.43$ & $\$ 174.61$ & 850 & $\$ 73.46$ & $\$ 624.41$ & $\$ 230.59$ \\
\hline$\$ 490.88$ & $\$ 30.28$ & $\$ 521.16$ & 750 & $\$ 75.79$ & $\$ 568.43$ & $\$ 47.27$ & 850 & $\$ 73.46$ & $\$ 624.41$ & $\$ 103.26$ & 950 & $\$ 69.93$ & $\$ 664.34$ & $\$ 143.18$ \\
\hline$\$ 463.50$ & $\$ 29.32$ & $\$ 492.82$ & 650 & $\$ 67.00$ & $\$ 435.50$ & $(\$ 57.32)$ & 750 & $\$ 64.55$ & $\$ 484.13$ & $(\$ 8.69)$ & 850 & $\$ 63.31$ & $\$ 538.14$ & $\$ 45.32$ \\
\hline$\$ 534.88$ & $\$ 30.28$ & $\$ 565.16$ & 750 & $\$ 64.55$ & $\$ 484.13$ & $(\$ 81.03)$ & 850 & $\$ 63.31$ & $\$ 538.14$ & $(\$ 27.02)$ & 950 & $\$ 60.50$ & $\$ 574.75$ & $\$ 9.60$ \\
\hline$\$ 423.00$ & $\$ 29.32$ & $\$ 452.32$ & 650 & $\$ 77.92$ & $\$ 506.48$ & $\$ 54.16$ & 750 & $\$ 77.31$ & $\$ 579.83$ & $\$ 127.51$ & 850 & $\$ 72.50$ & $\$ 616.25$ & $\$ 163.93$ \\
\hline$\$ 473.33$ & $\$ 30.28$ & $\$ 503.61$ & 750 & $\$ 77.31$ & $\$ 579.83$ & $\$ 76.22$ & 850 & $\$ 72.50$ & $\$ 616.25$ & $\$ 112.64$ & 950 & $\$ 65.00$ & $\$ 617.50$ & $\$ 113.89$ \\
\hline$\$ 501.75$ & $\$ 29.32$ & $\$ 531.07$ & 650 & $\$ 86.67$ & $\$ 563.36$ & $\$ 32.29$ & 750 & $\$ 82.94$ & $\$ 622.05$ & $\$ 90.98$ & 850 & $\$ 76.64$ & $\$ 651.44$ & $\$ 120.37$ \\
\hline$\$ 574.75$ & $\$ 30.28$ & $\$ 605.03$ & 750 & $\$ 82.94$ & $\$ 622.05$ & $\$ 17.02$ & 850 & $\$ 76.64$ & $\$ 651.44$ & $\$ 46.41$ & 950 & $\$ 72.25$ & $\$ 686.38$ & $\$ 81.35$ \\
\hline
\end{tabular}




\section{CHAPTER V}

Summary, Conclusions, and Recommendations

\section{Purpose of the Study}

The purpose of this study was to analyze price data for yearling beef cattle sold in the state of West Virginia between 1988 and 2003 to determine if a price protection option in yearling cattle production was feasible and obtainable. This study analyzed price trends over the period and identified the times when prices made it impossible for producers to make a profitable return on their product. This study identified market trends, including the evaluation of how weight classes impact price received. The study analyzed prices in relation to gain and analyzed market potential for various weight groups. It also examined how various factors such as seasons of the year and weather patterns affected cattle prices.

This study used an ex post facto research design. Case studies were utilized to compare individual producer prices versus statewide prices. The comparisons between the data sets allowed for research into regional pricing and local challenges that other West Virginia producers do not encounter. The comparison data sets also provided a window of research into price protection and allowed the researcher to analyze how the individuals in the case study could have benefited from price protection options.

\section{Objectives}

The objectives of this study were to identify beef cattle pricing trends over the past fourteen years to study individual beef producer pricing trends to compare cattle and compare them with the state average, as well as, analyze market challenges present in West Virginia. In identifying the stated objectives the data will allow the researcher to determine how market price protection could potentially benefit the state's cattle producers. 


\section{Conclusions}

Data exists to analyze price trends and determine risk assessments for yearling beef cattle in West Virginia on both the individual producer and overall state levels. The data set of 131,825 head of cattle was used. A total of 3,759 lots sold provided the basis to establish trends and market issues that were present in the state of West Virginia. Four very different production operations were used in the case studies. The case studies investigated sales and market prices endured by the producers. The data set was the most comprehensive set of prices and market reports that have been compiled in the state.

A price protection option would have assisted the producers in the case studies. The following highlights support this conclusion. Based on the case study data, the more diverse the operation and the more the producer had to buy cattle, the more risk was evident. This statement was based on the fact that producers have more entry barriers, such as higher prices and buying options to the market including they must purchase the cattle, provide initial turn out costs, transport the animals, and cover the cost of putting the gain on the animals. In a production operation where the calves were bred, raised and sold on the local farm, producers have fewer risks because the factor of buying cattle at the current market price to start the feeding cycle is eliminated.

Operations that were less diverse were more likely to manage the risks and less likely to benefit from a revenue insurance program. The case studies used in this study were very different in their make-up and allowed the researcher to study different facets of the market. Based upon the data, it was found that Case Study 3 would have been least likely to benefit from an insurance option. This could be partially due to the fact that the operation raised their own 
cattle and all of the cattle were black M grade. This allowed the operator to manage the risk and insure years of profitability.

Using the case study data, there were years where individual producer prices were below state averages. This phenomenon could be explained by numerous factors such as weather, type of cattle, or lack of animal gain. Revenue insurance doesn't care what caused the loss. The insurance will assist the producer to maintain profit or breakeven revenues for his/her operation.

The decision to use price protection options and the situations when price protection options will be beneficial must be made on a case-by-case basis at the producer level. While three of the four case studies had years when they could have benefited from a protection option, it does not mean that all operations of that type would benefit from the protection option. The procedures used in this study will serve as a guide to help producers understand how to look at personal records and compare them to state level data to assess if they could benefit from revenue insurance. Revenue insurance programs were based on personal Schedule F forms. It is essential that producers complete a personal price analysis of their operation and not base their decision on another farmer's findings.

Cattle sold in the 600-669 and 700-799 weight classes were at the greatest risk of revenue loss in the state. In the cost breakout scenario it was found that when the cattle were sold in these two weight classes they were more likely to sustain a loss. In analyzing the market data, it was found that a combined total of $63.9 \%$ and 2,904 lots of cattle were sold in 600-799 weight classes. This allowed the researchers to assume that the producers marketing cattle at this weight were enduring additional market risk by selling their cattle in the more vulnerable market weight classes. It was found that when cattle reach the 800 and above weight classes that they were less 
likely to report a market loss. However, in the data collected approximately $30 \%$ of the yearling cattle sold were in the 800 and above weight classes.

Even with the market fluctuations it was possible to make a profit if the cattle were raised and sold in the desired grade and weight category. Based on the analyses in this study, grade and weight class were the most important factors in marketing your cattle in West Virginia. It wasn't until the cattle hit the 800 and above weight ranges that the market stabilized and producers could expect a profit. This should be an incentive to West Virginia farmers to strive for the 800 plus pound market weight and $\mathrm{M}$ grade in order to reduce their production and market risks.

\section{Recommendations}

In conclusion several recommendations can be made. The first recommendation is that more research be conducted in this field. While this study attempted to identify if a price protection option could be useful in West Virginia, more research should be done on the benefits of revenue protection to individual producers. Secondly, this study examined cattle sold in 9,000 pounds or greater lots. A study should be done to assess smaller producers that may not be selling cattle in lots of this magnitude and determine if the smaller producers are witnessing the same market risks.

This study also opens the door to programming opportunities in the state of West Virginia. This study clearly identifies that market risks were present in the beef cattle operations in the state of West Virginia. With West Virginia serving as a pilot state in the AGR-Lite program, cattle producers across the state should be educated on how this program can truly be incorporated into their operations.

The Extension service can play a major role in assisting with the everyday operations of the local farmer. A local farmer may not be able or willing to conduct this type of analysis on a 
personal basis. A general data set and programming technique should be developed to assist individual farmers in determining their risk. It could have an impact of thousands or millions of dollars of beef cattle revenue across the state.

This study looked at a pricing history and identified that there were definitely years when a pricing option would have benefited producers, however, this study did not look at the years that the pricing option would not have assisted. Research needs to be conducted to analyze the cost of revenue insurances and how they would benefit the producer in the long run. It is essential to maximize your market prices in years when the prices are low, but it needs to be determined if in years of profit the cost of the revenue insurance would be feasible.

Revenue insurance is a very new product and one that many producers in the state and across the country do not fully understand. In order to assist farmers in understanding the program and the value of the insurance. Producers must be shown the benefits of the insurance program. It is essential to be able to track the money returned to the producer in years of loss and it is important to have estimated costs to the farmers. 


\section{REFERENCES}

Gray, A. W., Richardson, J. W., and McClasky, J. (1994). Farm-level impacts of revenue insurance. Unpublished report, Department of Agricultural Economics, Texas A\&M University.

Hart, C. E, Babcock, B. A., and Hayes, D. J. (2000). Livestock revenue insurance. Working Paper, Center for Agricultural and Rural Development, Iowa State University.

Hennessy, D. A., Babcock, B. A., and Hayes, D. J. (1997). Budgetary and producer welfare effects on revenue insurance. American Journal of Agricultural Economics, 79, 1024-34.

Innes, R. (2003). Crop insurance in a political economy: An alternative perspective on agricultural policy. American Journal of Agricultural Economics, 85, 318-33.

McKissick, J. C., Martin, N. R., and Kolajo, E. F. (1989). Alternative pricing methods reduce risks with stocker cattle. Alabama Agricultural Experiment Station Report, 36, 10.

U.S. Congress, Congressional Budget Office (CBO). (1983). Farm revenue insurance: An alternative risk management option for crop farmers. CBO Report. 
APPENDIX A 
APPENDIX A

Cattle Prices by Year, Month, Grade, Breed, Weight Class

\begin{tabular}{|c|c|c|c|c|c|c|c|c|c|c|c|c|c|c|c|c|}
\hline Year & Gender & Grade & Breed & Weight & Jan & Feb & Mar & Apr & Jun & Jul & Aug & Sep & Oct & Nov & Dec & Total \\
\hline \multirow[t]{15}{*}{1988} & Steers & $\mathrm{L}$ & Black & $800-899$ & & & & & & & & $\$ 72.00$ & & & & $\$ 72.00$ \\
\hline & & & & $900-999$ & & & & & & $\$ 66.25$ & & & & & & $\$ 66.25$ \\
\hline & & & & $\begin{array}{l}1100- \\
1199\end{array}$ & & & & & & $\$ 65.00$ & & $\$ 66.00$ & & & & $\$ 65.33$ \\
\hline & & $\mathrm{M}$ & Black & 600-699 & & & & 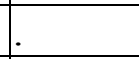 & & 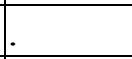 & & $\$ 82.25$ & & & & $\$ 82.25$ \\
\hline & & & & \begin{tabular}{|l|}
$700-799$ \\
\end{tabular} & & & & $\$ 81.00$ & & & $\$ 72.25$ & $\$ 79.07$ & & & & $\$ 79.01$ \\
\hline & & & & $800-899$ & & & & $\$ 75.75$ & & . & $\$ 70.00$ & $\$ 75.45$ & & & & $\$ 75.16$ \\
\hline & & & & $900-999$ & & & & $\$ 71.75$ & & & $\$ 67.75$ & $\$ 73.02$ & & & & $\$ 72.63$ \\
\hline & & & & $\begin{array}{l}1000- \\
1099\end{array}$ & & & & $\$ 70.25$ & & $\$ 68.00$ & $\$ 67.50$ & $\$ 71.40$ & & & & $\$ 70.33$ \\
\hline & & & & $\begin{array}{l}1100- \\
1199\end{array}$ & & & & $\$ 70.50$ & & & & $\$ 66.75$ & & & & $\$ 68.63$ \\
\hline & & $\mathrm{S}$ & Black & $700-799$ & & & & & & & & $\$ 70.50$ & & & & $\$ 70.50$ \\
\hline & Heifers & $\mathrm{L}$ & Black & 600-699 & & & & $\$ 76.25$ & & . & . & & & 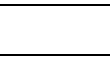 & & $\$ 76.25$ \\
\hline & & & & $700-799$ & & & & & & $\$ 69.25$ & $\$ 71.25$ & $\$ 72.00$ & & 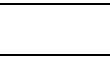 & & $\$ 70.83$ \\
\hline & & $\mathrm{M}$ & Black & 600-699 & & & & $\$ 74.81$ & & . & 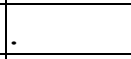 & $\$ 76.04$ & & & & $\$ 75.59$ \\
\hline & & & & $700-799$ & & & & $\$ 72.75$ & & . & . & $\$ 73.31$ & & & & $\$ 73.23$ \\
\hline & & & & $800-899$ & & & & $\$ 71.38$ & & $\$ 65.50$ & & $\$ 68.50$ & & & & $\$ 69.05$ \\
\hline \multirow[t]{9}{*}{1989} & Steers & $\mathrm{L}$ & Black & 600-699 & & & & $\$ 75.00$ & & . & $f^{\circ}$ & $\$ 80.75$ & $\$ 79.33$ & & & $\$ 78.97$ \\
\hline & & & & 700-799 & & & & $\$ 71.00$ & & . & + & & $\$ 74.75$ & & & $\$ 73.81$ \\
\hline & & & & $800-899$ & & & & $\$ 71.00$ & & . & . & $\$ 77.00$ & & . & & $\$ 74.00$ \\
\hline & & & & $900-999$ & & & & $\$ 64.50$ & & . & $\$ 74.00$ & & & . & & $\$ 69.25$ \\
\hline & & $\mathrm{M}$ & Black & 600-699 & & & & $\$ 78.25$ & & . & 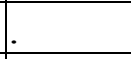 & $\$ 83.00$ & $\$ 82.19$ & & & $\$ 81.35$ \\
\hline & & & & $700-799$ & & & & $\$ 75.00$ & & 5 & $\$ 82.15$ & $\$ 76.75$ & & & & $\$ 79.10$ \\
\hline & & & & $800-899$ & & & & $\$ 67.75$ & & 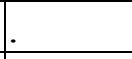 & $\$ 77.46$ & & . & & & $\$ 76.25$ \\
\hline & & & & $900-999$ & & & & $\$ 64.50$ & & 1. & $\$ 73.08$ & & . & 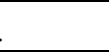 & & $\$ 70.94$ \\
\hline & & & & 1000- & & & & & & Tor & $\$ 72.00$ & & . & & & $\$ 72.00$ \\
\hline
\end{tabular}




\begin{tabular}{|c|c|c|c|c|c|c|c|c|c|c|c|c|c|c|c|c|}
\hline Year & Gender & Grade & Breed & Weight & Jan & Feb & Mar & Apr & Jun & Jul & Aug & Sep & Oct & Nov & Dec & Total \\
\hline \multirow[t]{20}{*}{1988} & Steers & $\mathrm{L}$ & Black & $800-899$ & & & & & & & & $\$ 72.00$ & & 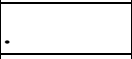 & & $\$ 72.00$ \\
\hline & & & & 1099 & & & & & & & & & & & & \\
\hline & & & BWF & $600-699$ & & & & $\$ 74.50$ & & & & & 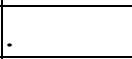 & $\cdot$ & 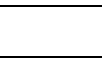 & $\$ 74.50$ \\
\hline & & & & $700-799$ & & & . &. & & & 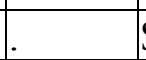 & $\$ 78.00$ & & . & 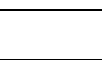 & $\$ 78.00$ \\
\hline & & & & $900-999$ & & & . & . & & & 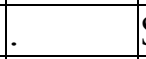 & $\$ 71.75$ & &. & 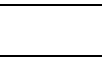 & $\$ 71.75$ \\
\hline & & & Charolais & $600-699$ & & & . & $\$ 81.00$ & & & $t$ & 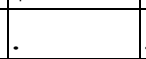 & . & . & 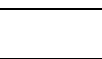 & $\$ 81.00$ \\
\hline & & & & $700-799$ & & & . & $\cdot$ & & & 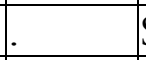 & $\$ \$ 78.50$ & & . & 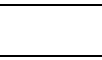 & $\$ 78.50$ \\
\hline & & & Hereford & $600-699$ & & & 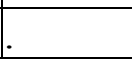 & $\$ 75.00$ & & & & & $\$ 82.75$ & & -1 & $\$ 78.88$ \\
\hline & & & & $700-799$ & & & . & T. & & & & $\$ 74.25$ & & . & 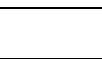 & $\$ 74.25$ \\
\hline & & & & $800-899$ & & & 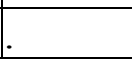 & . & & & & $\$ 71.25$ & & . & 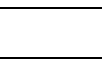 & $\$ 71.25$ \\
\hline & & & $\operatorname{Simmenta}_{1}$ & $700-799$ & & & & . & & & & $\$ 78.50$ & & . & & $\$ 78.50$ \\
\hline & & & & 800-899 & & & & $\$ 74.00$ & & & & & & . & 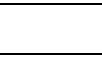 & $\$ 74.00$ \\
\hline & Heifers & $\mathrm{L}$ & Black & 600-699 & & & & $\$ 71.00$ & & & & $\$ 74.13$ & $\$ 74.00$ & & 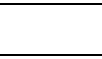 & $\$ 73.04$ \\
\hline & & & & $700-799$ & & & . & 5 & & & $\$ \$ 77.83$ & & & . & 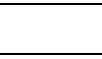 & $\$ 77.83$ \\
\hline & & $\mathrm{M}$ & Black & 600-699 & & & . & $\$ 68.50$ & & & $\$ 76.00$ & $\$ 72.13$ & $\$ 75.13$ & 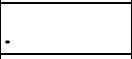 & & $\$ 72.50$ \\
\hline & & & & $700-799$ & & & 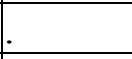 &. & & & $\$ \$ 78.19$ & & &. & 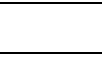 & $\$ 78.19$ \\
\hline & & & BWF & 600-699 & & & $E$ & . & & & 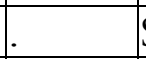 & $\$ 70.63$ & & . & 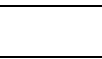 & $\$ 70.63$ \\
\hline & & & Charolais & 600-699 & & & - & $\$ 74.00$ & & & 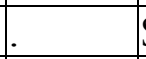 & $\$ 75.50$ & &. & 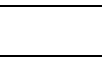 & $\$ 74.75$ \\
\hline & & & Hereford & 600-699 & & & . & . & & & 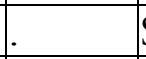 & $\$ 67.13$ & &. & 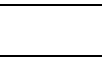 & $\$ 67.13$ \\
\hline & & $\mathrm{S}$ & Black & 600-699 & & & . & . & & & . & $\$ 72.25$ & & . & 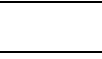 & $\$ 72.25$ \\
\hline \multirow[t]{9}{*}{1990} & Steers & $\mathrm{L}$ & Black & 600-699 & & & . & . & & & . & $\$ 85.08$ & $\$ 83.65$ & $\$ 83.25$ & 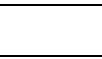 & $\$ 83.93$ \\
\hline & & & & $700-799$ & & & . & $\$ 75.00$ & & & . & $\$ 85.00$ & $\$ 81.60$ & & 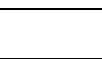 & $\$ 81.63$ \\
\hline & & & & $800-899$ & & & . & . & & & . & $\$ 81.25$ & $\$ 91.00$ & $\$ 82.50$ & 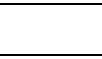 & $\$ 84.00$ \\
\hline & & & & $900-999$ & & & . & $\$ 74.25$ & & & $t$ & $\$ 79.75$ & & . & 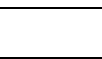 & $\$ 77.92$ \\
\hline & & & & $\begin{array}{l}1000- \\
1099\end{array}$ & & & & . & & & & $\$ 76.25$ & & $\cdot \cdot$ & & $\$ 76.25$ \\
\hline & & & BWF & $800-899$ & & & $\cdot$ & $\$ 79.75$ & & & + & 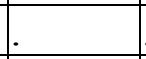 & &. & 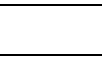 & $\$ 79.75$ \\
\hline & & & Charolais & 600-699 & & & 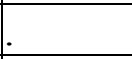 & $\$ 92.38$ & & & $0^{\circ}$ & . & . &. & 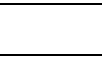 & $\$ 92.38$ \\
\hline & & & & $700-799$ & & & $\$ 77.25$ & $\$ 80.75$ & & & $f^{\circ}$ & & & . & 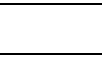 & $\$ 79.58$ \\
\hline & & & & $800-899$ & & & . & $\$ 76.00$ & & & $\$ 82.70$ & & &. & & $\$ 79.35$ \\
\hline
\end{tabular}




\begin{tabular}{|c|c|c|c|c|c|c|c|c|c|c|c|c|c|c|c|c|}
\hline Year & Gender & Grade & Breed & Weight & Jan & Feb & Mar & Apr & Jun & Jul & Aug & Sep & Oct & Nov & Dec & Total \\
\hline \multirow[t]{27}{*}{1988} & Steers & $\mathrm{L}$ & Black & $800-899$ & & & 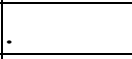 & & & & & $\$ 72.00$ & & 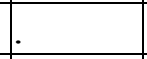 & - & $\$ 72.00$ \\
\hline & & & Hereford & $700-799$ & & & . & $\$ 83.00$ & & & . & & . & $\cdot$ & 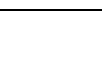 & $\$ 83.00$ \\
\hline & & & $\begin{array}{l}\text { Simmenta } \\
1\end{array}$ & $900-999$ & & & $\$ 71.00$ & & & & & & & & & $\$ 71.00$ \\
\hline & & $\mathrm{M}$ & Black & $600-699$ & & & $\$ 84.50$ & $\$ 92.50$ & & & & $\$ 85.03$ & $\$ 85.42$ & $\$ 85.75$ & & $\$ 85.78$ \\
\hline & & & & $700-799$ & & &. & $\$ 83.00$ & & & & $\$ 83.69$ & $\$ 80.50$ & $\$ 86.00$ & & $\$ 83.07$ \\
\hline & & & & $800-899$ & & &. & & & & $\$ 83.40$ & $\$ 80.50$ & & $\$ 86.50$ & & $\$ 82.28$ \\
\hline & & & & 900-999 & & & -5 & & & & & $\$ 76.50$ & & . & 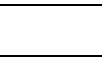 & $\$ 76.50$ \\
\hline & & & & $\begin{array}{l}1000- \\
1099\end{array}$ & & & $\$ 73.75$ & & & & & $\$ 75.00$ & &. & 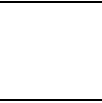 & $\$ 74.38$ \\
\hline & & & BWF & $600-699$ & & & $\$ 84.50$ & $\$ 91.20$ & & & . & $\$ 83.00$ & & $\cdot$ & 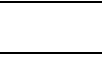 & $\$ 89.07$ \\
\hline & & & & $700-799$ & & & $\$ 80.00$ & $\$ 78.50$ & & & . & $\$ 81.25$ & & $0^{\circ}$ & 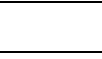 & $\$ 79.56$ \\
\hline & & & & $800-899$ & & & . & $\$ 76.25$ & & & . & . & . & . & 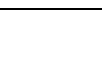 & $\$ 76.25$ \\
\hline & & & Charolais & 600-699 & & & . & $\$ 89.50$ & & & . &. & . & $\cdot$ & 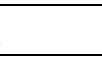 & $\$ 89.50$ \\
\hline & & & & $700-799$ & & & $\$ 73.75$ & & & & $\$ 84.25$ & & 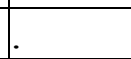 & . & 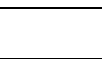 & $\$ 79.00$ \\
\hline & & & & $800-899$ & & & 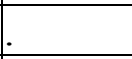 & & & & $\$ 82.70$ & & 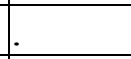 & & 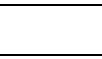 & $\$ 82.70$ \\
\hline & & & Hereford & $600-699$ & & & . & 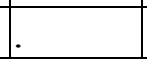 & & & + & . & $\$ 78.50$ & & 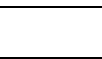 & $\$ 78.50$ \\
\hline & & S & Black & 600-699 & & & . & $\$ 93.00$ & & & . & & + & . & 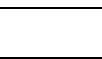 & $\$ 93.00$ \\
\hline & & & BWF & $800-899$ & & & $\$ 68.75$ & & & & . & & 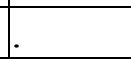 & & 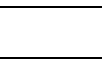 & $\$ 68.75$ \\
\hline & Heifers & $\mathrm{L}$ & Black & 600-699 & & & & $\$ 81.00$ & & & . & $\$ 80.42$ & $\$ 79.92$ & & 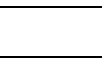 & $\$ 80.29$ \\
\hline & & & & 700-799 & & & . & & & & . & $\$ 82.25$ & & & 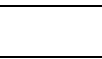 & $\$ 82.25$ \\
\hline & & & & $800-899$ & & & $\cdot$ & . & & & . & $\$ 77.00$ & & $\cdot$ & 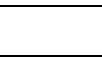 & $\$ 77.00$ \\
\hline & & & Charolais & 600-699 & & & 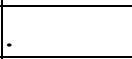 & $\$ 80.17$ & & & + & & . & . & 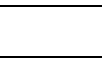 & $\$ 80.17$ \\
\hline & & & & 700-799 & & & & $\$ 80.75$ & & & $\$ 84.13$ & & . & 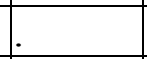 & 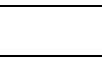 & $\$ 83.00$ \\
\hline & & $\mathrm{M}$ & Black & 600-699 & & &. & $\$ 78.50$ & & & + & $\$ 80.75$ & $\$ 76.33$ & & 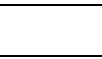 & $\$ 79.03$ \\
\hline & & & & 700-799 & & &. & $\$ 76.50$ & & & . & $\$ 78.35$ & & . & 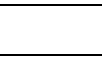 & $\$ 77.82$ \\
\hline & & & BWF & 600-699 & & & $\$ 75.50$ & $\$ 80.25$ & & & 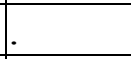 & & . & . & 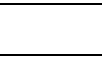 & $\$ 79.06$ \\
\hline & & & & 700-799 & & & 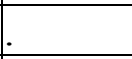 & $\$ 78.00$ & & & 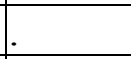 & . & . & . & 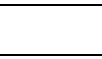 & $\$ 78.00$ \\
\hline & & & Charolais & 700-799 & & & 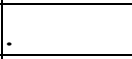 & . & & & $\$ 84.13$ & & $f$ & 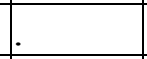 & 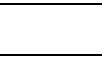 & $\$ 84.13$ \\
\hline \multirow[t]{2}{*}{1991} & Steers & $\mathrm{L}$ & Black & $600-699$ & & & . & $\$ 97.38$ & & & $\$ 83.25$ & $\$ 86.50$ & $\$ 85.75$ & & 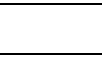 & $\$ 90.05$ \\
\hline & & & & $700-799$ & & & & & & & $\$ 80.50$ & & $\$ 80.50$ & & & $\$ 80.50$ \\
\hline
\end{tabular}




\begin{tabular}{|c|c|c|c|c|c|c|c|c|c|c|c|c|c|c|c|c|}
\hline \multirow{3}{*}{\begin{tabular}{|c} 
Year \\
1988 \\
\end{tabular}} & Gender & Grade & Breed & Weight & Jan & Feb & Mar & Apr & Jun & Jul & Aug & Sep & Oct & Nov & Dec & Total \\
\hline & Steers & $\mathrm{L}$ & Black & $800-899$ & & & & & & & & $\$ 72.00$ & & & & $\$ 72.00$ \\
\hline & & & & $800-899$ & & & & $\$ 82.25$ & & & $\$ 79.25$ & & & & & $\$ 81.25$ \\
\hline & & & & $900-999$ & & & & & & & $\$ 74.25$ & & & & & $\$ 74.25$ \\
\hline & & & & $\begin{array}{l}1000- \\
1099\end{array}$ & & & & & & & $\$ 71.00$ & & & & & $\$ 71.00$ \\
\hline & & & BWF & $600-699$ & & & & & & & & & $\$ 81.25$ & & & $\$ 81.25$ \\
\hline & & & & $700-799$ & & & & & & & & $\$ 79.13$ & & & & $\$ 79.13$ \\
\hline & & & & $800-899$ & & & & & & & & & $\$ 75.00$ & & & $\$ 75.00$ \\
\hline & & & & 900-999 & & & & & & & & $\$ 71.92$ & & & & $\$ 71.92$ \\
\hline & & & & $\begin{array}{l}1000- \\
1099\end{array}$ & & & & & & & & $\$ 62.50$ & & & & $\$ 62.50$ \\
\hline & & & Charolais & $600-699$ & & & & & & & & $\$ 81.42$ & $\$ 81.90$ & & & $\$ 81.72$ \\
\hline & & & & $700-799$ & & & & & & & $\$ 79.75$ & $\$ 78.92$ & $\$ 78.88$ & & & $\$ 79.04$ \\
\hline & & & & $800-899$ & & & & & & & $\$ 80.60$ & $\$ 75.42$ & & & & $\$ 76.71$ \\
\hline & & & & 900-999 & & & & & & & $\$ 78.25$ & & $\$ 68.25$ & & & $\$ 73.25$ \\
\hline & & & & $\begin{array}{l}1000- \\
1099\end{array}$ & & & & & & & & & $\$ 64.00$ & & & $\$ 64.00$ \\
\hline & & & Hereford & $600-699$ & & & & & & & & $\$ 75.33$ & $\$ 76.00$ & & & $\$ 75.50$ \\
\hline & & & & 700-799 & & & & $\$ 87.75$ & & & $\$ 77.25$ & $\$ 78.25$ & $\$ 75.63$ & & & $\$ 78.71$ \\
\hline & & & $\begin{array}{l}\text { Simmenta } \\
1\end{array}$ & 600-699 & & & & $\$ 96.25$ & & & & & & & & $\$ 96.25$ \\
\hline & & $\mathrm{M}$ & Black & $600-699$ & & & & $\$ 95.81$ & & & $\$ 83.00$ & $\$ 83.56$ & $\$ 84.79$ & $\$ 82.00$ & & $\$ 86.95$ \\
\hline & & & & $700-799$ & & & & $\$ 88.67$ & & & $\$ 83.08$ & $\$ 78.11$ & $\$ 76.00$ & & & $\$ 80.63$ \\
\hline & & & & $800-899$ & & & & $\$ 88.00$ & & & $\$ 81.50$ & $\$ 77.95$ & $\$ 76.25$ & & & $\$ 79.67$ \\
\hline & & & & 900-999 & & & & & & & $\$ 73.00$ & & $\$ 71.00$ & & & $\$ 72.00$ \\
\hline & & & & $\begin{array}{l}1000- \\
1099\end{array}$ & & & & & & & & $\$ 73.00$ & & & & $\$ 73.00$ \\
\hline & & & BWF & 600-699 & & & & $\begin{array}{l}\$ 100.2 \\
5\end{array}$ & & & & $\$ 83.94$ & $\$ 79.67$ & $\$ 85.00$ & & $\$ 84.44$ \\
\hline & & & & 700-799 & & & & & & & $\$ 80.00$ & $\$ 79.93$ & $\$ 76.38$ & & & $\$ 79.23$ \\
\hline & & & & $800-899$ & & & & & & & $\$ 84.00$ & $\$ 79.50$ & & $\$ 75.50$ & & $\$ 79.67$ \\
\hline
\end{tabular}




\begin{tabular}{|c|c|c|c|c|c|c|c|c|c|c|c|c|c|c|c|c|}
\hline Year & Gender & Grade & Breed & Weight & Jan & Feb & Mar & Apr & Jun & Jul & Aug & Sep & Oct & Nov & Dec & Total \\
\hline \multirow[t]{26}{*}{1988} & Steers & $\mathrm{L}$ & Black & $800-899$ & & & & & & & & $\$ 72.00$ & & & & $\$ 72.00$ \\
\hline & & & & $900-999$ & & & & & & & & $\$ 74.13$ & $\$ 70.00$ & & & $\$ 72.75$ \\
\hline & & & Charolais & $600-699$ & & & & $\$ 96.75$ & & & & & $\$ 78.63$ & & & $\$ 84.67$ \\
\hline & & & & 700-799 & & & & & & & $\$ 87.50$ & $\$ 80.75$ & & & & $\$ 84.13$ \\
\hline & & & Hereford & $600-699$ & & & & $\$ 94.13$ & & & & $\$ 73.00$ & $\$ 78.00$ & & & $\$ 84.81$ \\
\hline & & & & $700-799$ & & & & & & & $\$ 78.25$ & $\$ 76.25$ & & & & $\$ 77.25$ \\
\hline & & & $\operatorname{Red} X$ & $800-899$ & & & & & & & $\$ 80.60$ & & & & & $\$ 80.60$ \\
\hline & Heifers & $\mathrm{L}$ & Black & $600-699$ & & & & $\$ 85.75$ & & & $\$ 77.50$ & $\$ 79.50$ & $\$ 75.63$ & & & $\$ 80.63$ \\
\hline & & & & $700-799$ & & & & $\$ 79.25$ & & & $\$ 76.75$ & $\$ 71.00$ & & & & $\$ 76.56$ \\
\hline & & & BWF & $600-699$ & & & & & & & & $\$ 75.75$ & $\$ 77.00$ & & & $\$ 76.38$ \\
\hline & & & & $700-799$ & & & & & & & & $\$ 75.25$ & & & & $\$ 75.25$ \\
\hline & & & & $800-899$ & & & & & & & & & $\$ 66.25$ & & & $\$ 66.25$ \\
\hline & & & Charolais & $600-699$ & & & & & & & $\$ 77.25$ & $\$ 75.38$ & $\$ 75.00$ & & & $\$ 75.75$ \\
\hline & & & & 700-799 & & & & & & $\$ 83.75$ & & $\$ 75.25$ & $\$ 74.50$ & & & $\$ 77.83$ \\
\hline & & & & $800-899$ & & & & & & & $\$ 78.85$ & $\$ 69.00$ & & & & $\$ 73.93$ \\
\hline & & & Hereford & $600-699$ & & & & & & & $\$ 70.50$ & $\$ 72.42$ & $\$ 70.00$ & & & $\$ 71.55$ \\
\hline & & & $\begin{array}{l}\text { Simmenta } \\
1\end{array}$ & $600-699$ & & & & $\$ 90.00$ & & & & & & & & $\$ 90.00$ \\
\hline & & $\mathrm{M}$ & Black & $600-699$ & & & & $\$ 84.00$ & & $\$ 84.25$ & $\$ 78.56$ & $\$ 73.92$ & $\$ 75.33$ & & & $\$ 77.43$ \\
\hline & & & & $700-799$ & & & & $\$ 84.50$ & & & $\$ 77.75$ & $\$ 73.63$ & $\$ 75.75$ & & & $\$ 77.05$ \\
\hline & & & & $800-899$ & & & & & & & & $\$ 70.25$ & & & & $\$ 70.25$ \\
\hline & & & BWF & $600-699$ & & & & & & $\$ 82.75$ & $\$ 77.25$ & $\$ 75.75$ & $\$ 76.50$ & & & $\$ 77.03$ \\
\hline & & & & $700-799$ & & & & & & & & $\$ 71.75$ & $\$ 74.50$ & & & $\$ 72.44$ \\
\hline & & & Charolais & $600-699$ & & & & & & & & $\$ 76.50$ & & & & $\$ 76.50$ \\
\hline & & & & $700-799$ & & & & & & & & $\$ 73.00$ & & & & $\$ 73.00$ \\
\hline & & & & $800-899$ & & & & & & & $\$ 78.85$ & & & & & $\$ 78.85$ \\
\hline & & & Hereford & $600-699$ & & & & & & $\$ 79.75$ & $\$ 73.25$ & $\$ 65.75$ & & & & $\$ 72.92$ \\
\hline \multirow[t]{3}{*}{1992} & Steers & $\mathrm{L}$ & Black & $600-699$ & & & & & & & & $\$ 75.00$ & $\$ 81.30$ & & & $\$ 80.25$ \\
\hline & & & & $700-799$ & & & & & & & & & $\$ 74.00$ & & & $\$ 74.00$ \\
\hline & & & & $\begin{array}{l}1000- \\
1099\end{array}$ & & & & & & & & & $\$ 68.75$ & & & $\$ 68.75$ \\
\hline
\end{tabular}




\begin{tabular}{|c|c|c|c|c|c|c|c|c|c|c|c|c|c|c|c|c|}
\hline Year & Gender & Grade & Breed & Weight & Jan & Feb & Mar & Apr & Jun & Jul & Aug & Sep & Oct & Nov & Dec & Total \\
\hline \multirow[t]{31}{*}{1988} & Steers & $\mathrm{L}$ & Black & $800-899$ & & & & & & & & $\$ 72.00$ & & & 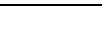 & $\$ 72.00$ \\
\hline & & & BWF & $600-699$ & & & & & & & & $\$ 82.25$ & $\$ 79.83$ & & 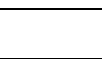 & $\$ 80.80$ \\
\hline & & & & $800-899$ & & & & & & & $\$ 79.25$ & & & & & $\$ 79.25$ \\
\hline & & & Charolais & $600-699$ & & & & & & & & $\$ 79.50$ & $\$ 75.93$ & $\$ 80.00$ & & $\$ 76.78$ \\
\hline & & & & $700-799$ & & & & & & & & $\$ 74.00$ & & & & $\$ 74.00$ \\
\hline & & & & 800-899 & & & & & & & . & & $\$ 78.00$ & & 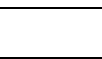 & $\$ 78.00$ \\
\hline & & & & $900-999$ & & & & & & & & & $\$ 74.00$ & & 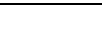 & $\$ 74.00$ \\
\hline & & & Hereford & $600-699$ & & & 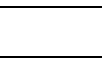 & & & & . & T & $\$ 74.13$ & & 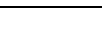 & $\$ 74.13$ \\
\hline & & $\mathrm{M}$ & Black & $600-699$ & & & & & & & . & $\$ 80.83$ & $\$ 82.08$ & & 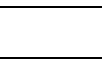 & $\$ 81.88$ \\
\hline & & & & $700-799$ & & & 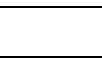 & & & & . & + & $\$ 75.75$ & $\$ 74.75$ & 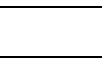 & $\$ 75.50$ \\
\hline & & & & 800-899 & & & & & & & $\$ 83.50$ & & $\$ 73.25$ & & 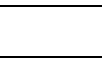 & $\$ 76.67$ \\
\hline & & & & $900-999$ & & & 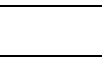 & & & & + & . & $\$ 73.50$ & & 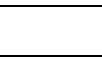 & $\$ 73.50$ \\
\hline & & & BWF & $600-699$ & & & & & & & . & $\$ 86.38$ & $\$ 82.75$ & $\$ 82.00$ & 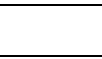 & $\$ 84.05$ \\
\hline & & & & 700-799 & & & & & & & 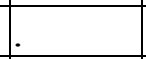 & & $\$ 75.75$ & $\$ 84.50$ & & $\$ 78.67$ \\
\hline & & & & $800-899$ & & & & & & & $\$ 79.25$ & & & $\$ 78.00$ & & $\$ 78.63$ \\
\hline & & & Charolais & $600-699$ & & & & & & & $\$ 86.50$ & $\$ 78.25$ & $\$ 78.50$ & & 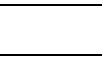 & $\$ 81.08$ \\
\hline & & & & $700-799$ & & & & & & & & & $\$ 77.50$ & & 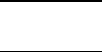 & $\$ 77.50$ \\
\hline & & & & $800-899$ & & & & & & & \begin{tabular}{|l|} 
\\
\end{tabular} & & $\$ 74.25$ & & 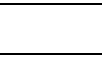 & $\$ 74.25$ \\
\hline & & & Hereford & $600-699$ & & & & & & & . & & $\$ 74.25$ & & & $\$ 74.25$ \\
\hline & & & $\operatorname{Red} X$ & $600-699$ & & & & & & & $\$ 86.50$ & & & & & $\$ 86.50$ \\
\hline & Heifers & $\mathrm{L}$ & Black & $600-699$ & & & & & & & & $\$ 70.50$ & $\$ 72.75$ & & 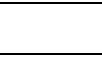 & $\$ 71.63$ \\
\hline & & & Charolais & $600-699$ & & & & & & & & $\$ 73.50$ & $\$ 74.92$ & & 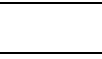 & $\$ 74.56$ \\
\hline & & & & 700-799 & & & & & & & $\$ 80.35$ & & . & . & 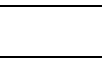 & $\$ 80.35$ \\
\hline & & & & $800-899$ & & & & & & & $\$ 81.75$ & & 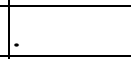 & . & 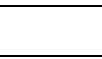 & $\$ 81.75$ \\
\hline & & & Hereford & $600-699$ & & & 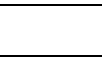 & - & & & 1 & . & $\$ 70.50$ & & 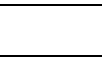 & $\$ 70.50$ \\
\hline & & & $\operatorname{Red} X$ & $700-799$ & & & & & & & $\$ 80.35$ & & 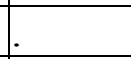 & $\cdot$ & 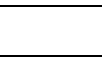 & $\$ 80.35$ \\
\hline & & $M$ & Black & $600-699$ & & & - & - & & & 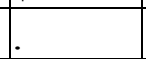 & . & $\$ 73.81$ & & 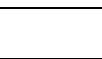 & $\$ 73.81$ \\
\hline & & & BWF & $600-699$ & & & 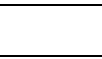 & & & &. & $\$ 76.00$ & $\$ 73.63$ & $\$ 76.50$ & & $\$ 74.94$ \\
\hline & & & & $700-799$ & & & & & & & $\$ 80.35$ & &. & 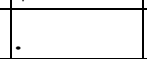 & 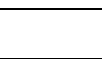 & $\$ 80.35$ \\
\hline & & & Charolais & $600-699$ & & & & & & & 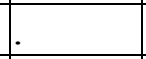 & $e^{\circ}$ & $\$ 73.25$ & & & $\$ 73.25$ \\
\hline & & & & 700-799 & & & & & & & $\$ 80.35$ & & $\$ 64.75$ & & & $\$ 72.55$ \\
\hline
\end{tabular}




\begin{tabular}{|c|c|c|c|c|c|c|c|c|c|c|c|c|c|c|c|c|}
\hline Year & Gender & Grad & Breed & Weight & Jan & Feb & Mar & Apr & Jun & Jul & Aug & Sep & Oct & Nov & Dec & Total \\
\hline \multirow[t]{2}{*}{1988} & Steers & $\mathrm{L}$ & Black & $800-899$ & & &. & & & & & $\$ 72.00$ & &. & & $\$ 72.00$ \\
\hline & & & & $800-899$ & & & . & & & & $\$ 86.25$ & & $\$ 63.00$ & . & & $\$ 74.63$ \\
\hline \multirow[t]{25}{*}{1993} & Steers & $\mathrm{L}$ & Black & $600-699$ & & & . & & & & & $\$ 83.75$ & & . & & $\$ 83.75$ \\
\hline & & & & 700-799 & & & . & . & & & $\$ 87.00$ & & 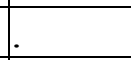 & . & & $\$ 87.00$ \\
\hline & & & & $800-899$ & & & . & & & & & $\$ 80.00$ & & . & & $\$ 80.00$ \\
\hline & & & BWF & 600-699 & & & . & . & & & . & $\$ 89.75$ & & . & & $\$ 89.75$ \\
\hline & & & & $700-799$ & & & . & 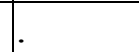 & & & $\$ 87.00$ & & & . & & $\$ 87.00$ \\
\hline & & & & $800-899$ & & & . & $\$ 80.00$ & & & $\$ 85.75$ & $\$ 83.00$ & & . & & $\$ 82.92$ \\
\hline & & & Charolais & $500-599$ & & & $\cdot$ & $\begin{array}{l}\$ 100.5 \\
0\end{array}$ & & & & & . & . & & $\begin{array}{l}\$ 100.5 \\
0\end{array}$ \\
\hline & & & & $600-699$ & & & . & $\$ 86.25$ & & & 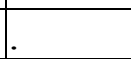 & & . & . & & $\$ 86.25$ \\
\hline & & & & 700-799 & & & . & $\$ 82.25$ & & & $\$ 84.25$ & & . & . & & $\$ 83.25$ \\
\hline & & & & $800-899$ & & & . & $\$ 79.63$ & & & $\$ 82.18$ & & & . & & $\$ 80.90$ \\
\hline & & & & $900-999$ & & & . & & & & $\$ 76.50$ & & . & . & & $\$ 76.50$ \\
\hline & & & $\mathrm{RN}$ & 700-799 & & & . & . & & & $\$ 85.00$ & & & . & & $\$ 85.00$ \\
\hline & & LM2 & Black & $600-699$ & & & . & . & & & $\$ 93.75$ & $\$ 89.75$ & & . & & $\$ 91.75$ \\
\hline & & & Charolais & 700-799 & & & . & $\$ 92.00$ & & & & & & . & & $\$ 92.00$ \\
\hline & & M & Black & 400-499 & & & . & $\begin{array}{l}\$ 114.0 \\
0\end{array}$ & & & & & & . & & $\begin{array}{l}\$ 114.0 \\
0\end{array}$ \\
\hline & & & & 500-599 & & & . & $\begin{array}{l}\$ 107.0 \\
0\end{array}$ & & & & $\$ 92.00$ & & . & & $\$ 99.50$ \\
\hline & & & & $600-699$ & & & . & $\$ 92.88$ & & & $\$ 92.13$ & $\$ 84.50$ & $\$ 89.00$ & $\$ 87.00$ & & $\$ 90.15$ \\
\hline & & & & $700-799$ & & & . & - & & & $\$ 87.16$ & $\$ 87.00$ & & $\$ 83.75$ & & $\$ 86.90$ \\
\hline & & & & $800-899$ & & & . & $\$ 79.50$ & & & $\$ 85.20$ & $\$ 85.38$ & & . & & $\$ 83.62$ \\
\hline & & & & 900-999 & & & . & $\$ 79.75$ & & & 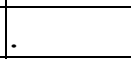 & & & . & & $\$ 79.75$ \\
\hline & & & BWF & 600-699 & & & $\$ 89.00$ & $\$ 93.73$ & & & $\$ 93.13$ & $\$ 86.00$ & $\$ 80.75$ & & & $\$ 92.40$ \\
\hline & & & & 700-799 & & & $\$ 82.75$ & $\$ 87.75$ & & & $\$ 90.86$ & $\$ 86.83$ & & . & & $\$ 88.22$ \\
\hline & & & & $800-899$ & & & $\$ 83.25$ & $\$ 80.25$ & & & $\$ 84.93$ & $\$ 83.25$ & & $\$ 79.44$ & & $\$ 81.59$ \\
\hline & & & & 900-999 & & & $\cdot$ & $\$ 78.25$ & & & & $\$ 74.00$ & & $\$ 75.50$ & & $\$ 75.92$ \\
\hline & & & Charolais & 400-499 & & & . & $\begin{array}{l}\$ 109.0 \\
0\end{array}$ & & & & & & +5 & & $\begin{array}{l}\$ 109.0 \\
0\end{array}$ \\
\hline
\end{tabular}




\begin{tabular}{|c|c|c|c|c|c|c|c|c|c|c|c|c|c|c|c|c|}
\hline Year & Gender & Grade & Breed & Weight & Jan & Feb & Mar & Apr & Jun & Jul & Aug & Sep & Oct & Nov & Dec & Total \\
\hline \multirow{30}{*}{1988} & Steers & $\mathrm{L}$ & Black & $800-899$ & & & & & & & & $\$ 72.00$ & & 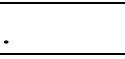 & 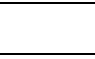 & $\$ 72.00$ \\
\hline & & & & $500-599$ & & & & $\begin{array}{l}\$ 103.0 \\
0\end{array}$ & & & & $\$ 90.50$ & & & 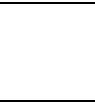 & $\$ 96.75$ \\
\hline & & & & $600-699$ & & & & $\$ 93.00$ & & & $\$ 92.69$ & $\$ 90.00$ & $\$ 95.00$ & & 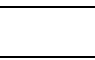 & $\$ 92.68$ \\
\hline & & & & $700-799$ & & & & $\$ 83.25$ & & & $\$ 85.14$ & $\$ 87.00$ & $\$ 76.50$ & & 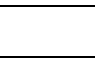 & $\$ 84.58$ \\
\hline & & & & $900-999$ & & & & . & & & $\$ 76.50$ & &. & . & 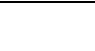 & $\$ 76.50$ \\
\hline & & & Hereford & $500-599$ & & & & $\$ 95.00$ & & & 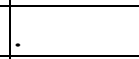 & & . &. & 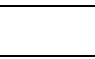 & $\$ 95.00$ \\
\hline & & & & $600-699$ & & & & $\$ 95.00$ & & & $\$ 84.50$ & $\$ 80.00$ & & . & 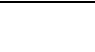 & $\$ 85.70$ \\
\hline & & & & $700-799$ & & & & . & & & $\$ 85.15$ & $\$ 83.50$ & & . & 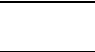 & $\$ 84.88$ \\
\hline & & & & $800-899$ & & & 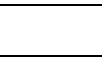 & . & & & $\$ 81.25$ & & . & . & 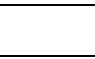 & $\$ 81.25$ \\
\hline & & & Limousin & $500-599$ & & & & . & & & & $\$ 90.50$ & & . & 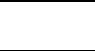 & $\$ 90.50$ \\
\hline & & & & 600-699 & & & & . & & & 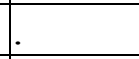 & $\$ 87.25$ & &. & 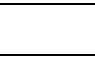 & $\$ 87.25$ \\
\hline & & & & $700-799$ & & & & 1 & & & $\$ 88.50$ & $\$ 85.25$ & & . & 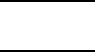 & $\$ 86.88$ \\
\hline & & $\mathrm{S}$ & BWF & 600-699 & & & & $\$ 84.25$ & & & & & . &. & 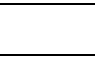 & $\$ 84.25$ \\
\hline & & & & $700-799$ & & & & . & & & $\$ 84.00$ & & . &. & 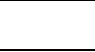 & $\$ 84.00$ \\
\hline & & & Charolais & $800-899$ & & & & . & & & $\$ 80.00$ & &. & . & 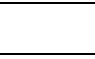 & $\$ 80.00$ \\
\hline & & & Hereford & $700-799$ & & & & . & & & $T$ & $\$ 84.25$ & &. & 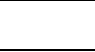 & $\$ 84.25$ \\
\hline & & & Limousin & 600-699 & & & & . & & & $\$ 88.50$ & & T &. & 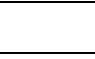 & $\$ 88.50$ \\
\hline & Heifers & $\mathrm{L}$ & Black & 600-699 & & & & . & & & $\$ 83.00$ & & $\$ 82.00$ & & 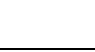 & $\$ 82.50$ \\
\hline & & & & $700-799$ & & & & . & & & $\$ 79.50$ & & $\cdot$ &. & 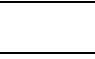 & $\$ 79.50$ \\
\hline & & & & $800-899$ & & & & . & & & $\$ 73.50$ & & . & . & 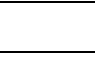 & $\$ 73.50$ \\
\hline & & & BWF & $600-699$ & & & 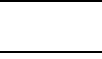 & . & & & $\$ 83.00$ & & . & . & 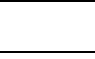 & $\$ 83.00$ \\
\hline & & & Charolais & 400-499 & & & & $\$ 94.50$ & & & . & $\cdot$ & . &. & 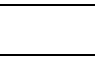 & $\$ 94.50$ \\
\hline & & & & 600-699 & & & &. & & & $\$ 83.96$ & &. &. & 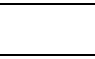 & $\$ 83.96$ \\
\hline & & & & $700-799$ & & & - & . & & & $\$ 80.33$ & & . & . & 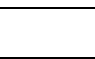 & $\$ 80.33$ \\
\hline & & & & $800-899$ & & & & $\theta^{\circ}$ & & & $\$ 81.25$ & & . & & 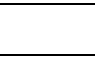 & $\$ 81.25$ \\
\hline & & & $\operatorname{Red} X$ & $600-699$ & & & 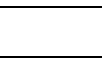 & 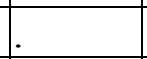 & & & $\$ 83.85$ & & . & . & 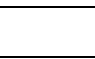 & $\$ 83.85$ \\
\hline & & $\mathrm{M}$ & Black & $400-499$ & & & & $\$ 97.00$ & & & & & 1 & & & $\$ 97.00$ \\
\hline & & & & $500-599$ & & & & $\$ 91.50$ & & & $\$ 90.13$ & $\$ 87.00$ & & & & $\$ 90.05$ \\
\hline & & & & $600-699$ & & & & $\$ 78.50$ & & & $\$ 85.04$ & & . & $\$ 77.00$ & & $\$ 83.42$ \\
\hline & & & & $700-799$ & & & & $\$ 74.00$ & & & $\$ 84.00$ & & 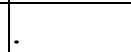 & 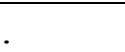 & & $\$ 80.67$ \\
\hline
\end{tabular}




\begin{tabular}{|c|c|c|c|c|c|c|c|c|c|c|c|c|c|c|c|c|}
\hline Year & Gender & Grade & Breed & Weight & Jan & Feb & Mar & Apr & Jun & Jul & Aug & Sep & Oct & Nov & Dec & Total \\
\hline \multirow{11}{*}{1988} & Steers & $\mathrm{L}$ & Black & $800-899$ & & & & & & & & $\$ 72.00$ & & & & $\$ 72.00$ \\
\hline & & & BWF & $500-599$ & & & & & & & $\$ 87.25$ & $\$ 87.00$ & & & & $\$ 87.13$ \\
\hline & & & & $600-699$ & & & & $\$ 79.21$ & & & $\$ 84.60$ & & & $\$ 80.13$ & & $\$ 81.42$ \\
\hline & & & & 700-799 & & & & $\$ 73.50$ & & & $\$ 84.25$ & & & & & $\$ 82.10$ \\
\hline & & & Charolais & $400-499$ & & & & $\$ 95.00$ & & & & & & & & $\$ 95.00$ \\
\hline & & & & $500-599$ & & & & & & & $\$ 89.88$ & & & & & $\$ 89.88$ \\
\hline & & & & $600-699$ & & & & $\$ 79.75$ & & & $\$ 83.03$ & $\$ 84.75$ & & & & $\$ 82.01$ \\
\hline & & & Hereford & $600-699$ & & & & & & & $\$ 76.75$ & & & & & $\$ 76.75$ \\
\hline & & & Limousin & $700-799$ & & & & & & & $\$ 84.00$ & & & & & $\$ 84.00$ \\
\hline & & $\mathrm{S}$ & Black & $500-599$ & & & & & & & & $\$ 85.75$ & & & & $\$ 85.75$ \\
\hline & & & BWF & $600-699$ & & & & $\$ 69.50$ & & & & & & & & $\$ 69.50$ \\
\hline \multirow[t]{20}{*}{1994} & Steers & $\mathrm{L}$ & Black & $500-599$ & & & & & & & & & $\$ 79.00$ & & & $\$ 79.00$ \\
\hline & & & & $600-699$ & & & & & & & $\$ 77.75$ & $\$ 72.17$ & $\$ 67.71$ & & & $\$ 70.05$ \\
\hline & & & & 700-799 & & & & & & & $\$ 71.50$ & $\$ 76.25$ & $\$ 66.50$ & & & $\$ 69.45$ \\
\hline & & & & $800-899$ & & & & & & & $\$ 71.17$ & $\$ 73.63$ & $\$ 64.75$ & & & $\$ 70.92$ \\
\hline & & & & $900-999$ & & & & & & & & & $\$ 60.38$ & & & $\$ 60.38$ \\
\hline & & & BWF & $600-699$ & & & & & & & & & $\$ 76.00$ & & & $\$ 76.00$ \\
\hline & & & & $700-799$ & & & & & & & $\$ 76.50$ & & $\$ 70.00$ & & & $\$ 73.25$ \\
\hline & & & & $800-899$ & & & & & & & & & $\$ 64.75$ & & & $\$ 64.75$ \\
\hline & & & & 900-999 & & & & & & & & & $\$ 60.25$ & & & $\$ 60.25$ \\
\hline & & & Charolais & $500-599$ & & & & & & & & & $\$ 79.00$ & & & $\$ 79.00$ \\
\hline & & & & $600-699$ & & & & & & & & & $\$ 68.62$ & & & $\$ 68.62$ \\
\hline & & & & 700-799 & & & & & & & $\$ 74.63$ & & $\$ 65.25$ & & & $\$ 69.94$ \\
\hline & & & & $800-899$ & & & & & & & $\$ 75.68$ & & & & & $\$ 75.68$ \\
\hline & & & & $900-999$ & & & & $\$ 70.00$ & & & & & & & & $\$ 70.00$ \\
\hline & & & Hereford & $700-799$ & & & & & & & & $\$ 74.00$ & $\$ 63.25$ & & & $\$ 68.63$ \\
\hline & & & & $800-899$ & & & & & & & $\$ 69.50$ & & & & & $\$ 69.50$ \\
\hline & & & Limousin & $700-799$ & & & & & & & $\$ 75.50$ & & $\$ 66.25$ & & & $\$ 70.88$ \\
\hline & & & & $800-899$ & & & & & & & & & $\$ 63.00$ & & & $\$ 63.00$ \\
\hline & & & $\operatorname{Red} X$ & 500-599 & & & & & & & & & $\$ 79.00$ & & & $\$ 79.00$ \\
\hline & & & & 700-799 & & & & & & & $\$ 75.00$ & & & & & $\$ 75.00$ \\
\hline
\end{tabular}




\begin{tabular}{|c|c|c|c|c|c|c|c|c|c|c|c|c|c|c|c|c|}
\hline \multirow{2}{*}{\begin{tabular}{|c|} 
Year \\
1988 \\
\end{tabular}} & Gender & Grade & Breed & Weight & Jan & Feb & Mar & Apr & Jun & Jul & Aug & Sep & Oct & Nov & Dec & Total \\
\hline & Steers & $\mathrm{L}$ & Black & $800-899$ & & & & & & & & $\$ 72.00$ & & & & $\$ 72.00$ \\
\hline & & & & $800-899$ & & & & & & & $\$ 74.44$ & & & & & $\$ 74.44$ \\
\hline & & LM2 & Black & $700-799$ & & & & & & & $\$ 76.50$ & & & & & $\$ 76.50$ \\
\hline & & & & $800-899$ & & & & & & & $\$ 74.75$ & & & & & $\$ 74.75$ \\
\hline & & & Hereford & $800-899$ & & & & & & & & & $\$ 62.00$ & & & $\$ 62.00$ \\
\hline & & $\mathrm{M}$ & Black & $400-499$ & & & & $\begin{array}{l}\$ 110.5 \\
0\end{array}$ & & & & & & & & $\begin{array}{l}\$ 110.5 \\
0\end{array}$ \\
\hline & & & & $500-599$ & & & & & & & & & $\$ 82.88$ & & & $\$ 82.88$ \\
\hline & & & & $600-699$ & & & & $\$ 90.30$ & & & $\$ 75.00$ & $\$ 71.92$ & $\$ 67.25$ & & & $\$ 74.80$ \\
\hline & & & & $700-799$ & & & & $\$ 81.08$ & & & $\$ 76.50$ & $\$ 72.91$ & $\$ 69.28$ & & & $\$ 73.16$ \\
\hline & & & & $800-899$ & & & & $\$ 75.00$ & & & $\$ 72.54$ & $\$ 69.17$ & $\$ 64.83$ & & & $\$ 70.49$ \\
\hline & & & & $900-999$ & & & & $\$ 72.00$ & & & & $\$ 66.75$ & & & & $\$ 69.38$ \\
\hline & & & BWF & $400-499$ & & & & $\begin{array}{l}\$ 115.0 \\
0\end{array}$ & & & & & & & & $\begin{array}{l}\$ 115.0 \\
0\end{array}$ \\
\hline & & & & $500-599$ & & & & $\begin{array}{l}\$ 115.0 \\
0\end{array}$ & & & & & $\$ 82.88$ & & & $\$ 85.80$ \\
\hline & & & & $600-699$ & & & & $\$ 89.61$ & & & & $\$ 71.50$ & $\$ 68.39$ & $\$ 69.00$ & & $\$ 79.83$ \\
\hline & & & & 700-799 & & & & $\$ 78.35$ & & & $\$ 78.00$ & $\$ 74.83$ & $\$ 69.85$ & $\$ 69.50$ & & $\$ 75.30$ \\
\hline & & & & $800-899$ & & & & $\$ 74.08$ & & & $\$ 73.21$ & $\$ 68.50$ & $\$ 64.13$ & $\$ 69.00$ & & $\$ 71.12$ \\
\hline & & & & $900-999$ & & & & $\$ 72.25$ & & & $\$ 69.75$ & $\$ 63.63$ & & & & $\$ 67.31$ \\
\hline & & & & $\begin{array}{l}1000- \\
1099\end{array}$ & & & & & & & & & & $\$ 64.25$ & & $\$ 64.25$ \\
\hline & & & Charolais & $400-499$ & & & & $\begin{array}{l}\$ 115.5 \\
0\end{array}$ & & & & & & & & $\begin{array}{l}\$ 115.5 \\
0\end{array}$ \\
\hline & & & & $500-599$ & & & & & & & & & $\$ 86.00$ & & & $\$ 86.00$ \\
\hline & & & & $600-699$ & & & & $\$ 87.25$ & & & & $\$ 70.50$ & $\$ 63.25$ & & & $\$ 73.78$ \\
\hline & & & & $700-799$ & & & & $\$ 78.50$ & & & $\$ 75.38$ & $\$ 74.88$ & $\$ 68.44$ & $\$ 68.00$ & & $\$ 72.08$ \\
\hline & & & & $800-899$ & & & & & & & $\$ 75.66$ & $\$ 68.17$ & $\$ 64.50$ & & & $\$ 71.59$ \\
\hline & & & & $900-999$ & & & & & & & & & $\$ 60.50$ & $\$ 67.00$ & & $\$ 63.75$ \\
\hline & & & Hereford & $500-599$ & & & & $\begin{array}{l}\$ 113.0 \\
0\end{array}$ & & & & & & & & $\begin{array}{l}\$ 113.0 \\
0\end{array}$ \\
\hline
\end{tabular}




\begin{tabular}{|c|c|c|c|c|c|c|c|c|c|c|c|c|c|c|c|c|}
\hline Year & Gender & Grade & Breed & Weight & Jan & Feb & Mar & Apr & Jun & Jul & Aug & Sep & Oct & Nov & Dec & Total \\
\hline \multirow[t]{31}{*}{1988} & Steers & $\mathrm{L}$ & Black & $800-899$ & & & & & & 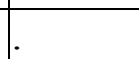 & & $\$ 72.00$ & & & 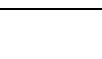 & $\$ 72.00$ \\
\hline & & & & $600-699$ & & & & & & . & & & $\$ 53.50$ & & 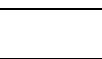 & $\$ 53.50$ \\
\hline & & & & $700-799$ & & & & & & & $\$ 73.00$ & $\$ 72.00$ & $\$ 64.13$ & & & $\$ 68.31$ \\
\hline & & & & $800-899$ & & & & & & . & & & $\$ 67.50$ & & 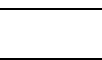 & $\$ 67.50$ \\
\hline & & & & $900-999$ & & & & & & & $\$ 68.00$ & & & & - & $\$ 68.00$ \\
\hline & & & Limousin & $600-699$ & & & & & & ]$^{\circ}$ & & $\$ 75.75$ & & & 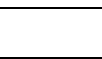 & $\$ 75.75$ \\
\hline & & & & $700-799$ & & & & & & + & $\$ 76.00$ & $\$ 73.75$ & $\$ 67.75$ & & 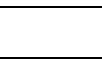 & $\$ 71.31$ \\
\hline & & & & $900-999$ & & & & & & . & + & . & $\$ 60.50$ & & 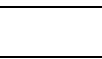 & $\$ 60.50$ \\
\hline & & & $\operatorname{Red} X$ & 500-599 & & & & & & . & t & & $\$ 86.00$ & & 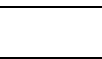 & $\$ 86.00$ \\
\hline & & & & $700-799$ & & & 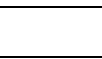 & . & & . & $\$ 75.50$ & $\$ 76.75$ & $\$ 71.00$ & & 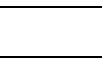 & $\$ 74.42$ \\
\hline & & & & $800-899$ & & & & & & . & & $\$ 71.25$ & $\$ 64.25$ & & 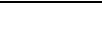 & $\$ 67.75$ \\
\hline & & $\mathrm{S}$ & Black & $700-799$ & & & 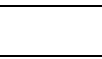 & . & & . & . & $\$ 69.50$ & & 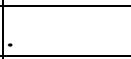 & 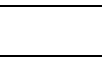 & $\$ 69.50$ \\
\hline & & & & $800-899$ & & & & & & . & $\$ 73.00$ & & . & . & 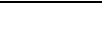 & $\$ 73.00$ \\
\hline & & & BWF & $800-899$ & & & & . & & . & $\$ 73.50$ & & . &. & 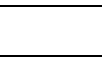 & $\$ 73.50$ \\
\hline & & & Charolais & $700-799$ & & & & & & . & . & $\$ 73.25$ & & . & 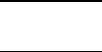 & $\$ 73.25$ \\
\hline & & & & $800-899$ & & & & & & . & 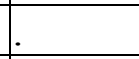 & $\$ 69.08$ & $\$ 64.25$ & & 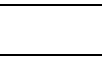 & $\$ 67.47$ \\
\hline & & & Hereford & $800-899$ & & & & & & 1 & $\$ 71.75$ & & & & 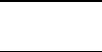 & $\$ 71.75$ \\
\hline & & & $\operatorname{Red} X$ & $700-799$ & & & & & & 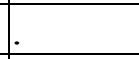 & $\$ 77.75$ & & $\$ 71.25$ & & 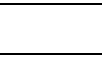 & $\$ 74.50$ \\
\hline & & & & $800-899$ & & & & & & . & & & $\$ 64.25$ & & 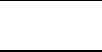 & $\$ 64.25$ \\
\hline & Heifers & $\mathrm{L}$ & Black & $500-599$ & & & & & & . & . & & $\$ 72.10$ & & 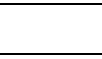 & $\$ 72.10$ \\
\hline & & & & $600-699$ & & & & & & 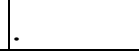 & . & . & $\$ 61.50$ & & 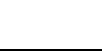 & $\$ 61.50$ \\
\hline & & & & $700-799$ & & & & & & $\$ 69.00$ & $\$ 76.00$ & & $\$ 62.75$ & & 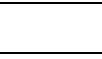 & $\$ 69.25$ \\
\hline & & & BWF & 800-899 & & & 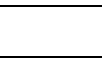 & & & . & 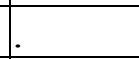 & . & 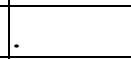 & $\$ 64.25$ & & $\$ 64.25$ \\
\hline & & & Charolais & $600-699$ & & & & . & & . & . &. & $\$ 65.75$ & & 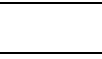 & $\$ 65.75$ \\
\hline & & & & 700-799 & & & 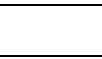 &. & & $\$ 73.75$ & $\$ 72.92$ & & $\$ 63.13$ & & 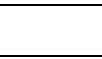 & $\$ 70.36$ \\
\hline & & & & $800-899$ & & & 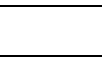 & . & & $\$ 68.00$ & $\$ 75.40$ & & $\mid \cdot$ & r. & 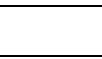 & $\$ 71.70$ \\
\hline & & & Limousin & $700-799$ & & & 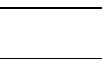 & . & & $\$ 75.50$ & $\$ 71.50$ & & . & . & 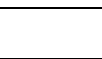 & $\$ 73.50$ \\
\hline & & & $\operatorname{Red} X$ & $500-599$ & & & 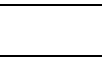 & $\cdot$ & & . & $f^{\circ}$ & 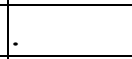 & $\$ 72.00$ & & 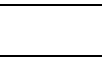 & $\$ 72.00$ \\
\hline & & & & $700-799$ & & & & . & & $\$ 73.50$ & & 4 &. & . & 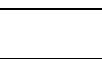 & $\$ 73.50$ \\
\hline & & $\mathrm{M}$ & Black & $400-499$ & & & & $\$ 92.00$ & & . &. & 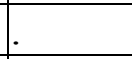 & 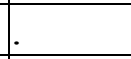 & 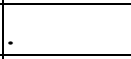 & & $\$ 92.00$ \\
\hline & & & & 500-599 & & & & $\$ 88.00$ & & 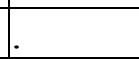 & 1 & 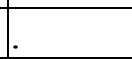 & $\$ 72.11$ & & & $\$ 74.09$ \\
\hline
\end{tabular}




\begin{tabular}{|c|c|c|c|c|c|c|c|c|c|c|c|c|c|c|c|c|}
\hline Year & Gender & Grade & Breed & Weight & Jan & Feb & Mar & Apr & Jun & Jul & Aug & Sep & Oct & Nov & Dec & Total \\
\hline \multirow[t]{20}{*}{1988} & Steers & $\mathrm{L}$ & Black & $800-899$ & & & & & & . & & $\$ 72.00$ & & . & 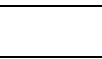 & $\$ 72.00$ \\
\hline & & & & $600-699$ & & & & $\$ 77.00$ & & $\$ 78.25$ & $\$ 73.93$ & $\$ 64.00$ & $\$ 61.42$ & & 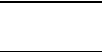 & $\$ 68.37$ \\
\hline & & & & $700-799$ & & & & $\$ 71.00$ & & $\$ 73.92$ & $\$ 73.50$ & $\$ 67.75$ & $\$ 63.00$ & $\$ 65.25$ & & $\$ 70.11$ \\
\hline & & & & $900-999$ & & & & $\$ 66.50$ & & & & & & . & & $\$ 66.50$ \\
\hline & & & BWF & $500-599$ & & & & & & & & & $\$ 72.11$ & & 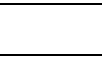 & $\$ 72.11$ \\
\hline & & & & $600-699$ & & & & $\$ 77.78$ & & $\$ 76.63$ & $\$ 73.68$ & $\$ 66.63$ & $\$ 59.63$ & $\$ 64.25$ & & $\$ 72.53$ \\
\hline & & & & $700-799$ & & & & $\$ 74.42$ & & $\$ 75.75$ & $\$ 73.50$ & & & $\$ 65.00$ & & $\$ 73.43$ \\
\hline & & & & $800-899$ & & & & $\$ 67.25$ & &. & I. & . & . & . & 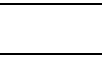 & $\$ 67.25$ \\
\hline & & & Charolais & 400-499 & & & & $\$ 95.50$ & &. & . & . & 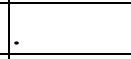 &. & 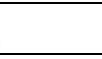 & $\$ 95.50$ \\
\hline & & & & $500-599$ & & & & $\$ 84.50$ & & . & 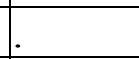 & 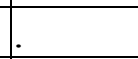 & $\$ 70.25$ & $0^{\circ}$ & 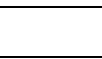 & $\$ 77.38$ \\
\hline & & & & $600-699$ & & & & $\$ 74.00$ & & . & $\$ 71.63$ & & $\$ 63.00$ & $\$ 63.25$ & 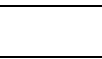 & $\$ 69.58$ \\
\hline & & & & 700-799 & & & & $\$ 71.25$ & & $\$ 74.00$ & $\$ 74.00$ & $\$ 69.75$ & & . & 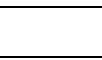 & $\$ 72.60$ \\
\hline & & & & 800-899 & & & & . & & & $\$ 75.40$ & & . & . & 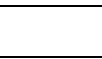 & $\$ 75.40$ \\
\hline & & & Hereford & $700-799$ & & & & . & & $\$ 70.00$ & & 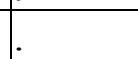 & . & . & 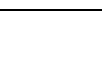 & $\$ 70.00$ \\
\hline & & & Limousin & 500-599 & & & & $\$ 84.00$ & &. & $f^{\circ}$ & . & . & . & 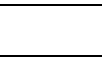 & $\$ 84.00$ \\
\hline & & & Red & $700-799$ & & & & . & & . & 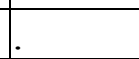 & $\$ 69.75$ & & . & 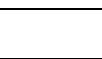 & $\$ 69.75$ \\
\hline & & & $\operatorname{Red} X$ & $500-599$ & & & & . & & . & 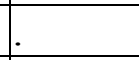 & & $\$ 72.00$ & & 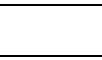 & $\$ 72.00$ \\
\hline & & & & $700-799$ & & & & $t^{2}$ & & + & $\$ 74.00$ & & F & . & 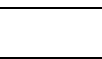 & $\$ 74.00$ \\
\hline & & $\mathrm{S}$ & Black & $600-699$ & & & & $\cdot$ & & . & & & $\$ 59.75$ & & 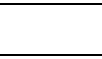 & $\$ 59.75$ \\
\hline & & & & $700-799$ & & & & & & $\$ 73.00$ & & & & & 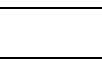 & $\$ 73.00$ \\
\hline \multirow[t]{11}{*}{1995} & Steers & $\mathrm{L}$ & Black & $600-699$ & & & & $\$ 82.50$ & & & $\$ 62.00$ & $\$ 59.75$ & $\$ 60.20$ & $\$ 57.00$ & & $\$ 62.16$ \\
\hline & & & & $700-799$ & & & & & & . & & $\$ 57.25$ & $\$ 62.75$ & & & $\$ 60.92$ \\
\hline & & & & 800-899 & & & & $\$ 66.50$ & & & $\$ 64.00$ & $\$ 62.63$ & & . & 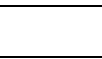 & $\$ 63.94$ \\
\hline & & & & $900-999$ & & & & & & & $\$ 60.42$ & & & 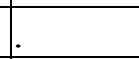 & 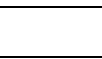 & $\$ 60.42$ \\
\hline & & & BWF & $600-699$ & & & &. & & $\cdot$ & . & & $\$ 62.17$ & & 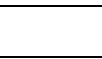 & $\$ 62.17$ \\
\hline & & & & $700-799$ & & & & . & & 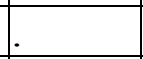 & $\$ 63.75$ & & + & . & 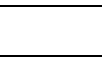 & $\$ 63.75$ \\
\hline & & & & 800-899 & & & & . & & . & $\$ 62.25$ & & . & . & 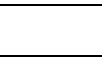 & $\$ 62.25$ \\
\hline & & & & $900-999$ & & & 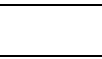 & 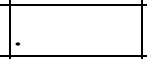 & & . & $t$ & $\$ 60.50$ & & . & 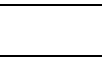 & $\$ 60.50$ \\
\hline & & & Charolais & $600-699$ & & & & . & & . & {$[\cdot$} & $\$ 56.50$ & $\$ 58.75$ & & 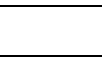 & $\$ 58.00$ \\
\hline & & & & $700-799$ & & & & $\$ 67.00$ & & . & . & $\$ 63.75$ & & . & 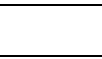 & $\$ 65.38$ \\
\hline & & & & 800-899 & & & & 5 & & 1 & $\$ 63.25$ & & $\$ 62.75$ & & 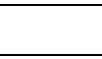 & $\$ 63.17$ \\
\hline
\end{tabular}




\begin{tabular}{|c|c|c|c|c|c|c|c|c|c|c|c|c|c|c|c|c|}
\hline \multirow{2}{*}{\begin{tabular}{|c|} 
Year \\
1988 \\
\end{tabular}} & Gender & Grade & Breed & Weight & Jan & Feb & Mar & Apr & Jun & Jul & Aug & Sep & Oct & Nov & Dec & Total \\
\hline & Steers & $\mathrm{L}$ & Black & $800-899$ & & & & & & & & $\$ 72.00$ & & & 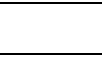 & $\$ 72.00$ \\
\hline & & & & $\begin{array}{l}1000- \\
1099\end{array}$ & & & & & & & & $\$ 54.50$ & & & 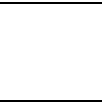 & $\$ 54.50$ \\
\hline & & & Hereford & $700-799$ & & & & & & & & $\$ 62.00$ & & & & $\$ 62.00$ \\
\hline & & & & $800-899$ & & & & . & & & $\$ 58.50$ & & & . & 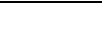 & $\$ 58.50$ \\
\hline & & & & $\begin{array}{l}1000- \\
1099\end{array}$ & & & & & & & $\$ 54.00$ & & & . & 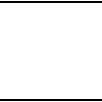 & $\$ 54.00$ \\
\hline & & & Limousin & 600-699 & & & &. & & & $\$ 63.75$ & & . & . & 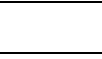 & $\$ 63.75$ \\
\hline & & & & $700-799$ & & & & & & & & & $\$ 64.38$ & & 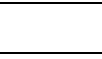 & $\$ 64.38$ \\
\hline & & & & $800-899$ & & & & $\cdot$ & & & $\$ 63.75$ & & $\$ 63.25$ & & 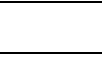 & $\$ 63.50$ \\
\hline & & $\mathrm{M}$ & Black & $400-499$ & & & & $\$ 85.00$ & & & & & . & . & 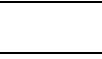 & $\$ 85.00$ \\
\hline & & & & $600-699$ & & & & $\$ 76.50$ & & & $\$ 66.88$ & $\$ 62.25$ & $\$ 64.00$ & & 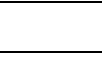 & $\$ 65.19$ \\
\hline & & & & $700-799$ & & & & $\$ 68.63$ & & & $\$ 62.97$ & $\$ 63.25$ & $\$ 62.19$ & & 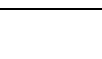 & $\$ 63.49$ \\
\hline & & & & $800-899$ & & & - & . & & & $\$ 64.60$ & $\$ 63.50$ & $\$ 63.25$ & & 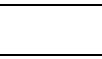 & $\$ 63.98$ \\
\hline & & & & $900-999$ & & & & . & & & $\$ 59.25$ & $\$ 60.75$ & $\$ 62.75$ & & 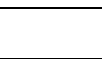 & $\$ 60.85$ \\
\hline & & & & $\begin{array}{l}1000- \\
1099\end{array}$ & & & & . & & & & & $\$ 60.50$ & & & $\$ 60.50$ \\
\hline & & & BWF & $600-699$ & & & & $\$ 77.50$ & & & . & $\$ 64.75$ & $\$ 64.75$ & $\$ 62.75$ & & $\$ 66.89$ \\
\hline & & & & 700-799 & & & & $\$ 69.25$ & & & $\$ 63.63$ & $\$ 65.25$ & $\$ 65.00$ & $\$ 63.50$ & & $\$ 64.73$ \\
\hline & & & & $800-899$ & & & & . & & & $\$ 64.95$ & $\$ 63.25$ & $\$ 63.00$ & $\$ 66.60$ & & $\$ 64.14$ \\
\hline & & & & 900-999 & & & & 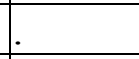 & & & & $\$ 61.75$ & & $\$ 65.18$ & & $\$ 64.03$ \\
\hline & & & Charolais & $400-499$ & & & & $\$ 81.00$ & & & & & & . & & $\$ 81.00$ \\
\hline & & & & $500-599$ & & & & $\$ 83.00$ & & & & & & $T$ & 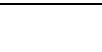 & $\$ 83.00$ \\
\hline & & & & $600-699$ & & & & $\$ 72.50$ & & & . & $\$ 62.50$ & $\$ 62.00$ & $\$ 59.75$ & & $\$ 63.85$ \\
\hline & & & & $700-799$ & & & & 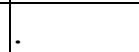 & & & $\$ 61.25$ & $\$ 62.88$ & $\$ 63.92$ & $\$ 62.00$ & & $\$ 62.58$ \\
\hline & & & & $800-899$ & & & & - & & & $\$ 64.06$ & $\$ 60.75$ & & . & 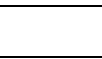 & $\$ 63.59$ \\
\hline & & & & $900-999$ & & & & . & & & $\$ 59.63$ & & $\$ 62.75$ & . & 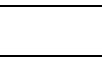 & $\$ 60.67$ \\
\hline & & & Hereford & $700-799$ & & & 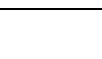 & . & & & $\$ 63.75$ & $\$ 59.38$ & $\$ 61.33$ & . & 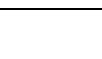 & $\$ 61.46$ \\
\hline & & & Limousin & 600-699 & & & 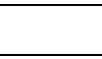 & . & & & 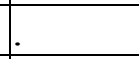 & $\$ 63.25$ & & . & 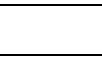 & $\$ 63.25$ \\
\hline & & & & $700-799$ & & & & $\$ 71.50$ & & & $\$ 62.25$ & $\$ 63.25$ & & . & 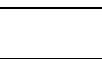 & $\$ 64.81$ \\
\hline & & & & $900-999$ & & & & 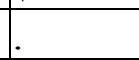 & & & + & $\$ 58.00$ & $\$ 62.75$ & 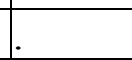 & 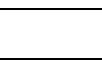 & $\$ 60.38$ \\
\hline
\end{tabular}




\begin{tabular}{|c|c|c|c|c|c|c|c|c|c|c|c|c|c|c|c|c|}
\hline Year & Gender & Grade & Breed & Weight & Jan & Feb & Mar & Apr & Jun & Jul & Aug & Sep & Oct & Nov & Dec & Total \\
\hline \multirow{31}{*}{1988} & Steers & $\mathrm{L}$ & Black & $800-899$ & & & & & & & & $\$ 72.00$ & & . & 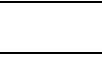 & $\$ 72.00$ \\
\hline & & & $\operatorname{Red} X$ & 800-899 & & & & & & & $\$ 63.00$ & & & & 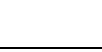 & $\$ 63.00$ \\
\hline & & $\mathrm{S}$ & Black & $600-699$ & & & & & & & & & $\$ 63.50$ & & 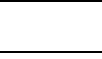 & $\$ 63.50$ \\
\hline & & & & $800-899$ & & & & & & & $\$ 61.25$ & & $\$ 63.25$ & & 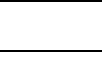 & $\$ 62.25$ \\
\hline & & & BWF & $700-799$ & & & & · & & & & & $\$ 63.25$ & & 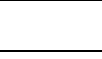 & $\$ 63.25$ \\
\hline & & & & $900-999$ & & & & . & & & $\$ 60.25$ & & & . & 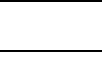 & $\$ 60.25$ \\
\hline & & & Charolais & $700-799$ & & & &. & & & $\$ 66.75$ & $\$ 64.00$ & &. & 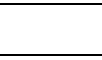 & $\$ 65.38$ \\
\hline & & & & $800-899$ & & & & 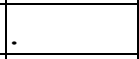 & & & $\$ 65.75$ & & . & . & 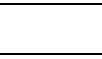 & $\$ 65.75$ \\
\hline & & & Limousin & $600-699$ & & & & . & & & $f$ & & $\$ 62.00$ & & 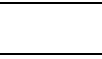 & $\$ 62.00$ \\
\hline & Heifers & $\mathrm{L}$ & Black & $600-699$ & & & & $\$ 61.75$ & & & $\$ 58.00$ & $\$ 59.25$ & $\$ 55.75$ & 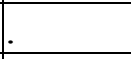 & 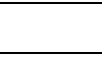 & $\$ 59.30$ \\
\hline & & & & $700-799$ & & & & . & & & $\$ 59.88$ & $\$ 59.00$ & $\$ 60.63$ & & 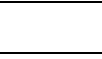 & $\$ 60.00$ \\
\hline & & & & 800-899 & & & 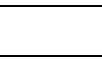 & . & & & $\$ 53.25$ & &. & . & 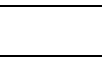 & $\$ 53.25$ \\
\hline & & & & $900-999$ & & & & . & & & $\$ 54.00$ & & . & 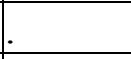 & 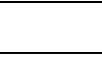 & $\$ 54.00$ \\
\hline & & & BWF & 700-799 & & & & . & & & . & 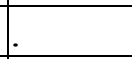 & . & $\$ 54.25$ & & $\$ 54.25$ \\
\hline & & & Charolais & $500-599$ & & & & $\$ 66.00$ & & &. & . & . & . & 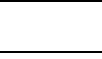 & $\$ 66.00$ \\
\hline & & & & $600-699$ & & & & $\$ 63.50$ & & & $\$ 58.50$ & $\$ 55.25$ & & 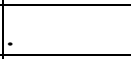 & 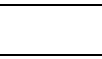 & $\$ 58.13$ \\
\hline & & & & $700-799$ & & & & $\$ 62.00$ & & & & $\$ 58.25$ & $\$ 60.38$ & & 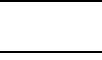 & $\$ 60.25$ \\
\hline & & & Limousin & $700-799$ & & & & 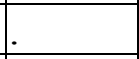 & & & $\$ 58.25$ & & . & . & 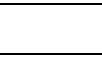 & $\$ 58.25$ \\
\hline & & $\mathrm{M}$ & Black & $400-499$ & & & & $\$ 71.00$ & & & & & . & . & 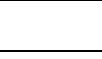 & $\$ 71.00$ \\
\hline & & & & $500-599$ & & & & $\$ 72.00$ & & & $\$ 58.25$ & & & . & 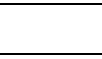 & $\$ 65.13$ \\
\hline & & & & $600-699$ & & & & $\$ 62.50$ & & & $\$ 61.06$ & $\$ 58.75$ & $\$ 52.85$ & & 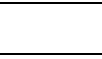 & $\$ 57.38$ \\
\hline & & & & $700-799$ & & & & & & & $\$ 62.17$ & $\$ 60.00$ & & 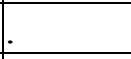 & 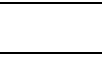 & $\$ 61.63$ \\
\hline & & & & $800-899$ & & & & . & & & $\$ 58.00$ & & $f$ &. & 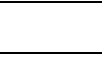 & $\$ 58.00$ \\
\hline & & & BWF & $500-599$ & & & & $\$ 72.00$ & & & & & 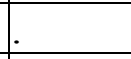 & 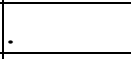 & 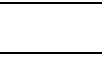 & $\$ 72.00$ \\
\hline & & & & $600-699$ & & & & $\$ 62.50$ & & & $\$ 61.42$ & $\$ 58.00$ & & $E$ & 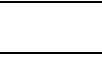 & $\$ 60.95$ \\
\hline & & & & $700-799$ & & & 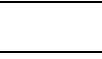 & 2 & & & $\$ 61.83$ & $\$ 58.25$ & & . & 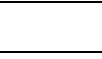 & $\$ 60.94$ \\
\hline & & & & $800-899$ & & & & . & & & 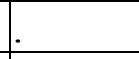 & $\$ 60.50$ & & . & 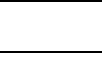 & $\$ 60.50$ \\
\hline & & & Charolais & $400-499$ & & & & $\$ 64.50$ & & &. & . & $e^{\circ}$ & . & 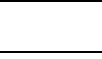 & $\$ 64.50$ \\
\hline & & & & $500-599$ & & & & $\$ 63.00$ & & &. & . & 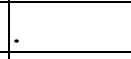 & . & 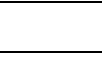 & $\$ 63.00$ \\
\hline & & & & $600-699$ & & & 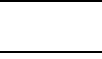 & 5 & & & $\$ 62.00$ & $\$ 58.00$ & $\$ 50.25$ & . & 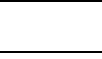 & $\$ 56.75$ \\
\hline & & & & $700-799$ & & & & 1 & & & $\$ 61.25$ & & 1 & . & 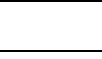 & $\$ 61.25$ \\
\hline
\end{tabular}




\begin{tabular}{|c|c|c|c|c|c|c|c|c|c|c|c|c|c|c|c|c|}
\hline Year & Gender & Grade & Breed & Weight & Jan & Feb & Mar & Apr & Jun & Jul & Aug & Sep & Oct & Nov & Dec & Total \\
\hline \multirow[t]{7}{*}{1988} & Steers & $\mathrm{L}$ & Black & $800-899$ & & & & & & . & & $\$ 72.00$ & & & - & $\$ 72.00$ \\
\hline & & & & $800-899$ & & & & . & & . & $\$ 61.50$ & & . & . & 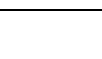 & $\$ 61.50$ \\
\hline & & & Hereford & $600-699$ & & & & . & &. & $\$ 56.25$ & & . & . & 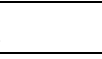 & $\$ 56.25$ \\
\hline & & & $\operatorname{Red} X$ & $600-699$ & & & 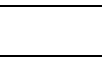 & . & & . & $\$ 62.00$ & & . &. & 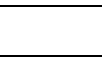 & $\$ 62.00$ \\
\hline & & & & $700-799$ & & & 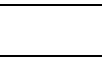 & . & & . & $\$ 61.50$ & & . &. & 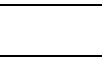 & $\$ 61.50$ \\
\hline & & & & $800-899$ & & & - & . & & . & $\$ 61.50$ & & . & . & 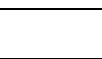 & $\$ 61.50$ \\
\hline & & $\mathrm{S}$ & Black & $600-699$ & & & & . & & . & $\$ 55.50$ & $\$ 55.75$ & & . & 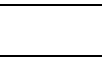 & $\$ 55.67$ \\
\hline \multirow[t]{23}{*}{1996} & Steers & $\mathrm{L}$ & Black & $600-699$ & & & & 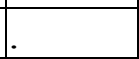 & & 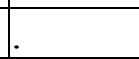 & & $\$ 52.42$ & $\$ 50.00$ & & 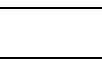 & $\$ 51.45$ \\
\hline & & & & $700-799$ & & & & & & $t$ & $\$ 61.00$ & $\$ 60.00$ & & & 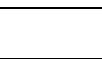 & $\$ 60.67$ \\
\hline & & & & $800-899$ & & & & $\$ 52.00$ & & . & $\$ 62.00$ & $\$ 60.25$ & $\$ 56.50$ & & 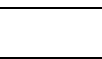 & $\$ 59.13$ \\
\hline & & & & $900-999$ & & & & & & . & $\$ 60.38$ & $\$ 55.75$ & $\$ 53.75$ & & 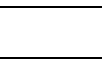 & $\$ 57.56$ \\
\hline & & & BWF & $600-699$ & & & & . & & 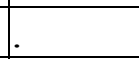 & 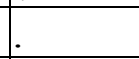 & & $\$ 56.50$ & & 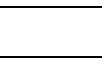 & $\$ 56.50$ \\
\hline & & & & $900-999$ & & & & & & + & $\$ 62.50$ & & & & 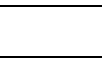 & $\$ 62.50$ \\
\hline & & & Charolais & $600-699$ & & & & . & & & & & $\$ 50.00$ & & 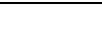 & $\$ 50.00$ \\
\hline & & & & 700-799 & & & & . & &. & $\$ 59.88$ & $\$ 57.08$ & & & 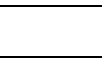 & $\$ 58.68$ \\
\hline & & & & 800-899 & & & & 7 & & $\$ 60.43$ & $\$ 61.92$ & $\$ 59.50$ & $\$ 54.13$ & & 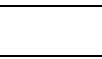 & $\$ 60.42$ \\
\hline & & & & $900-999$ & & & & $\cdot$ & & $u^{\circ}$ & $\$ 58.50$ & $\$ 53.75$ & $\$ 52.50$ & & 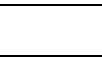 & $\$ 54.92$ \\
\hline & & & Hereford & $900-999$ & & & & . & & . & 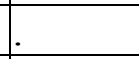 & & $\$ 49.75$ & & 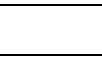 & $\$ 49.75$ \\
\hline & & & Limousin & 700-799 & & & & . & & . & $\$ 58.75$ & & 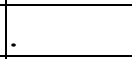 & . & 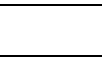 & $\$ 58.75$ \\
\hline & & & & $800-899$ & & & 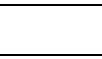 & $T$ & & . & 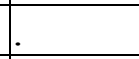 & . & $\$ 52.75$ & & 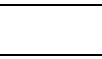 & $\$ 52.75$ \\
\hline & & & & $900-999$ & & & & . & & . & $\$ 58.50$ & & 1 & . & 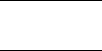 & $\$ 58.50$ \\
\hline & & & $\operatorname{Red} X$ & $800-899$ & & & 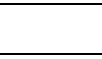 & 7 & & $\$ 60.75$ & $\$ 62.10$ & & . & . & 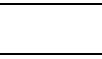 & $\$ 61.88$ \\
\hline & & & $\begin{array}{l}\text { Simmenta } \\
1\end{array}$ & $600-699$ & & & & . & &. & 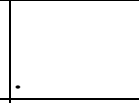 & & $\$ 45.00$ & & 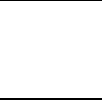 & $\$ 45.00$ \\
\hline & & $\mathrm{M}$ & Black & $600-699$ & & & 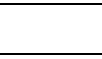 & $\$ 60.50$ & & 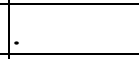 & $\$ 63.50$ & $\$ 62.06$ & $\$ 56.10$ & $\$ 56.13$ & & $\$ 58.15$ \\
\hline & & & & 700-799 & & & & $\$ 59.25$ & & $\$ 61.75$ & $\$ 63.50$ & $\$ 60.75$ & $\$ 59.81$ & & & $\$ 61.34$ \\
\hline & & & & $800-899$ & & & & $\$ 52.00$ & & $\$ 60.85$ & $\$ 62.66$ & $\$ 57.00$ & $\$ 55.00$ & & 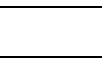 & $\$ 60.94$ \\
\hline & & & & $900-999$ & & & & & & & $\$ 62.50$ & $\$ 59.50$ & & & & $\$ 61.00$ \\
\hline & & & BWF & 500-599 & & & & . & & & $\$ 57.50$ & & & & & $\$ 57.50$ \\
\hline & & & & $600-699$ & & & & $\$ 57.28$ & & & $\$ 63.25$ & $\$ 63.25$ & $\$ 56.63$ & $\$ 56.25$ & & $\$ 58.39$ \\
\hline & & & & $700-799$ & & & & $\$ 52.21$ & & $\$ 61.75$ & $\$ 63.35$ & $\$ 58.97$ & $\$ 61.75$ & & & $\$ 58.52$ \\
\hline
\end{tabular}




\begin{tabular}{|c|c|c|c|c|c|c|c|c|c|c|c|c|c|c|c|c|}
\hline Year & Gender & Grade & Breed & Weight & Jan & Feb & Mar & Apr & Jun & Jul & Aug & Sep & Oct & Nov & Dec & Total \\
\hline \multirow[t]{31}{*}{1988} & Steers & $\mathrm{L}$ & Black & $800-899$ & & & & & & & & $\$ 72.00$ & & & & $\$ 72.00$ \\
\hline & & & & $800-899$ & & & & $\$ 46.92$ & & $\$ 60.85$ & $\$ 62.71$ & $\$ 59.00$ & $\$ 58.00$ & & & $\$ 56.26$ \\
\hline & & & & $900-999$ & & & & & & & $\$ 62.50$ & & & & & $\$ 62.50$ \\
\hline & & & Charolais & $500-599$ & & & & . & & . & $\$ 55.00$ & & 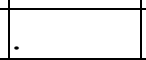 & & 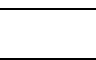 & $\$ 55.00$ \\
\hline & & & & $600-699$ & & & & $\$ 49.00$ & & & $\$ 61.00$ & $\$ 55.50$ & $\$ 61.00$ & & & $\$ 55.17$ \\
\hline & & & & 700-799 & & & & $\$ 48.50$ & & & $\$ 59.38$ & $\$ 58.25$ & $\$ 57.42$ & & 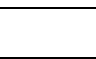 & $\$ 55.30$ \\
\hline & & & & $800-899$ & & & & 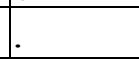 & & $\$ 60.10$ & $\$ 62.81$ & $\$ 57.25$ & & & & $\$ 61.43$ \\
\hline & & & Hereford & $600-699$ & & & & . & & 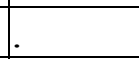 & $\$ 54.50$ & & . & & & $\$ 54.50$ \\
\hline & & & & $700-799$ & & & & . & & 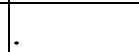 & $\$ 57.00$ & $\$ 55.08$ & $\$ 55.50$ & & & $\$ 55.54$ \\
\hline & & & & $800-899$ & & & 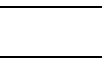 & . & & . & & $\$ 54.50$ & & t & 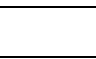 & $\$ 54.50$ \\
\hline & & & Limousin & $600-699$ & & & & . & & 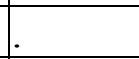 & $\$ 61.00$ & & . & & & $\$ 61.00$ \\
\hline & & & Mixed & $700-799$ & & & 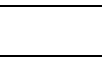 & . & & . & + & $j^{\circ}$ & $\$ 62.50$ & & & $\$ 62.50$ \\
\hline & & & & 800-899 & & & & & & + & 1 & . & $\$ 62.25$ & & & $\$ 62.25$ \\
\hline & & & $\operatorname{Red} X$ & $800-899$ & & & & . & & $f$ & $\$ 62.25$ & & 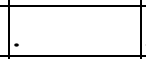 & & & $\$ 62.25$ \\
\hline & & S & Black & $600-699$ & & & & . & & . & $\$ 56.67$ & $\$ 53.00$ & $\$ 53.17$ & & & $\$ 54.64$ \\
\hline & & & & 700-799 & & & & & & . & $\$ 62.00$ & & $\$ 51.25$ & & & $\$ 56.63$ \\
\hline & & & Charolais & $600-699$ & & & & & & & & & $\$ 53.50$ & & & $\$ 53.50$ \\
\hline & & & Hereford & $900-999$ & & & & 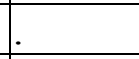 & & & $\$ 52.50$ & & & & & $\$ 52.50$ \\
\hline & Heifers & $\mathrm{L}$ & Black & $600-699$ & & & & $\$ 39.25$ & & & & $\$ 53.00$ & & & & $\$ 46.13$ \\
\hline & & & & $700-799$ & & & & $\$ 41.50$ & & $\$ 55.00$ & $\$ 53.38$ & $\$ 54.63$ & $\$ 49.88$ & & & $\$ 51.92$ \\
\hline & & & & 800-899 & & & & & & & & & $\$ 44.00$ & & & $\$ 44.00$ \\
\hline & & & BWF & $600-699$ & & & & $\$ 43.17$ & & & & & 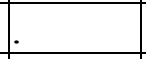 & & & $\$ 43.17$ \\
\hline & & & & 700-799 & & & & 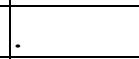 & & $\$ 57.25$ & & . & . & - & & $\$ 57.25$ \\
\hline & & & & $800-899$ & & & & . & & ]$^{\circ}$ & 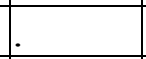 & $\$ 52.00$ & & & & $\$ 52.00$ \\
\hline & & & Charolais & 500-599 & & & 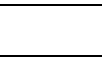 & . & & . & . & $\$ 51.50$ & & & & $\$ 51.50$ \\
\hline & & & & $600-699$ & & & & $\$ 48.00$ & & 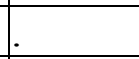 & $\$ 55.50$ & $\$ 54.63$ & $\$ 43.00$ & & & $\$ 51.32$ \\
\hline & & & & $700-799$ & & & & $\$ 45.00$ & & $\$ 53.44$ & $\$ 56.63$ & & 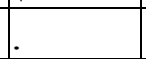 & & & $\$ 53.14$ \\
\hline & & & & $800-899$ & & & & . & & 1. & $\$ 47.25$ & & 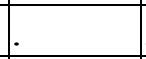 & & & $\$ 47.25$ \\
\hline & & & Limousin & $600-699$ & & & - & 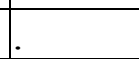 & & . & + & $t$ & $\$ 46.75$ & & & $\$ 46.75$ \\
\hline & & & & $700-799$ & & & & - & & $\$ 53.75$ & & $e^{\circ}$ & . & & & $\$ 53.75$ \\
\hline & & & $\operatorname{Red} X$ & $700-799$ & & & & & & + & $\$ 57.42$ & & 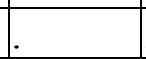 & & & $\$ 57.42$ \\
\hline
\end{tabular}




\begin{tabular}{|c|c|c|c|c|c|c|c|c|c|c|c|c|c|c|c|c|}
\hline Year & Gender & Grade & Breed & Weight & Jan & Feb & Mar & Apr & Jun & Jul & Aug & Sep & Oct & Nov & Dec & Total \\
\hline \multirow[t]{17}{*}{1988} & Steers & $\mathrm{L}$ & Black & $800-899$ & & & & & & 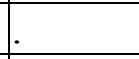 & & $\$ 72.00$ & & & & $\$ 72.00$ \\
\hline & & $\mathrm{M}$ & Black & $500-599$ & & & 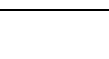 & . & & . & $\$ 45.00$ & $\$ 50.25$ & & & 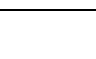 & $\$ 47.63$ \\
\hline & & & & $600-699$ & & & & $\$ 48.62$ & & $\$ 54.50$ & $\$ 56.00$ & $\$ 52.63$ & $\$ 47.00$ & & 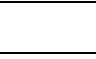 & $\$ 50.07$ \\
\hline & & & & $700-799$ & & & & $\$ 41.50$ & & $\$ 55.67$ & $\$ 58.88$ & & $t$ & & 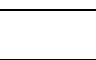 & $\$ 54.38$ \\
\hline & & & BWF & 500-599 & & & 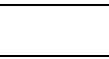 & $e^{\circ}$ & & . & & $\$ 50.25$ & . & & 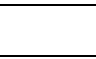 & $\$ 50.25$ \\
\hline & & & & $600-699$ & & & & $\$ 51.05$ & & $\$ 54.50$ & $\$ 57.00$ & $\$ 54.25$ & 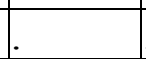 & & 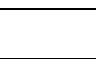 & $\$ 51.98$ \\
\hline & & & & 700-799 & & & & $\$ 46.50$ & & $\$ 56.06$ & $\$ 58.88$ & & . & & 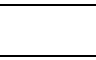 & $\$ 52.80$ \\
\hline & & & & $800-899$ & & & & $\$ 50.75$ & & 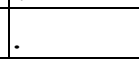 & & & . & & & $\$ 50.75$ \\
\hline & & & Charolais & 600-699 & & & & $\$ 42.50$ & & . & - & • & . & & - & $\$ 42.50$ \\
\hline & & & & $700-799$ & & & & $\$ 43.00$ & & . & $F^{\prime}$ & & $t$ & & & $\$ 43.00$ \\
\hline & & & Hereford & $600-699$ & & & & & & & & & $\$ 46.00$ & & & $\$ 46.00$ \\
\hline & & & Mixed & $600-699$ & & & & $\cdot$ & & $\$ 53.75$ & & & . & & 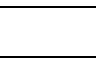 & $\$ 53.75$ \\
\hline & & & & 700-799 & & & & . & & $\$ 56.50$ & & & . & & 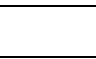 & $\$ 56.50$ \\
\hline & & & $\operatorname{Red} X$ & $700-799$ & & & & . & & $\$ 55.50$ & & & $t$ & & & $\$ 55.50$ \\
\hline & & $\mathrm{S}$ & Black & 500-599 & & & & . & & & $\$ 50.25$ & & $\$ 56.75$ & & - & $\$ 53.50$ \\
\hline & & & & 600-699 & & & & . & & . & $\$ 47.50$ & & $\$ 47.25$ & & & $\$ 47.38$ \\
\hline & & & Charolais & 500-599 & & & & . & & . &. & $\cdot$ & $\$ 54.25$ & & & $\$ 54.25$ \\
\hline \multirow[t]{12}{*}{1997} & Steers & $\mathrm{L}$ & Black & 600-699 & & & & . & & . & 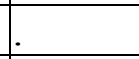 & & $\$ 72.33$ & & & $\$ 72.33$ \\
\hline & & & & $700-799$ & & & & $\cdot$ & & 1 & $\$ 77.25$ & $\$ 76.50$ & $\$ 74.08$ & & & $\$ 75.20$ \\
\hline & & & & $800-899$ & & & 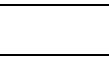 & . & & $\$ 75.75$ & $\$ 71.00$ & $\$ 74.50$ & $\$ 75.00$ & & & $\$ 73.75$ \\
\hline & & & & 900-999 & & & &. & & 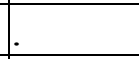 & $\$ 68.75$ & $\$ 69.75$ & $\$ 63.50$ & & & $\$ 67.90$ \\
\hline & & & & $\begin{array}{l}1000- \\
1099\end{array}$ & & & & & & {$[\cdot$} & $\$ 64.00$ & & 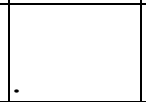 & & & $\$ 64.00$ \\
\hline & & & & $\begin{array}{l}1100- \\
1199\end{array}$ & & & & 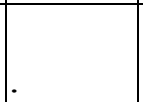 & & & & $\$ 62.25$ & & & & $\$ 62.25$ \\
\hline & & & BWF & 600-699 & & & & $\cdot$ & & $\cdot$ & $f^{\circ}$ & . & $\$ 71.50$ & & & $\$ 71.50$ \\
\hline & & & & 700-799 & & & & $\$ 69.75$ & & . & 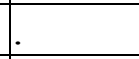 & 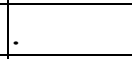 & $f$ & & & $\$ 69.75$ \\
\hline & & & & $800-899$ & & & & . & & + & . & 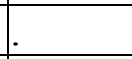 & $\$ 62.00$ & & & $\$ 62.00$ \\
\hline & & & Charolais & 600-699 & & & & $\$ 79.00$ & & . & & $\$ 69.00$ & $\$ 62.50$ & & & $\$ 70.17$ \\
\hline & & & & $700-799$ & & & & (2) & & $f^{\circ}$ & $\$ 76.20$ & $\$ 72.00$ & $\$ 76.00$ & & & $\$ 75.32$ \\
\hline & & & & $800-899$ & & & & & & $\$ 75.75$ & $\$ 72.13$ & $\$ 68.75$ & & & & $\$ 72.19$ \\
\hline
\end{tabular}




\begin{tabular}{|c|c|c|c|c|c|c|c|c|c|c|c|c|c|c|c|c|}
\hline Year & Gender & Grade & Breed & Weight & Jan & Feb & Mar & Apr & Jun & Jul & Aug & Sep & Oct & Nov & Dec & Total \\
\hline \multirow[t]{28}{*}{1988} & Steers & $\mathrm{L}$ & Black & $800-899$ & & & $\cdot$ & & & & & $\$ 72.00$ & & & & $\$ 72.00$ \\
\hline & & & & $900-999$ & & & . & & & $\$ 75.13$ & $\$ 67.25$ & $\$ 63.75$ & $\$ 59.50$ & & & $\$ 68.00$ \\
\hline & & & & $\begin{array}{l}1000- \\
1099\end{array}$ & & & & & & & $\$ 67.25$ & & & & & $\$ 67.25$ \\
\hline & & & Hereford & $900-999$ & & & . & & & . & $\$ 63.75$ & & &. & & $\$ 63.75$ \\
\hline & & & Limousin & $800-899$ & & & . & & & . & $\$ 74.00$ & $\$ 68.75$ & $\$ 70.25$ & & & $\$ 71.00$ \\
\hline & & & & $900-999$ & & & . & . & & . & $\$ 64.25$ & $\$ 63.75$ & & 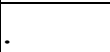 & & $\$ 64.00$ \\
\hline & & & $\operatorname{Red} X$ & $700-799$ & & & . & . & & T & & & $\$ 77.25$ & & & $\$ 77.25$ \\
\hline & & & & $800-899$ & & & . & . & & $\$ 75.75$ & $\$ 73.55$ & & & . & & $\$ 73.92$ \\
\hline & & & & $900-999$ & & & . & . & & $\$ 76.00$ & $\$ 70.50$ & & . & . & & $\$ 72.33$ \\
\hline & & $\mathrm{M}$ & Black & $500-599$ & & & . & $\$ 89.25$ & & & & & & . & & $\$ 89.25$ \\
\hline & & & & $600-699$ & & & . & $\$ 86.83$ & & & $\$ 82.88$ & $\$ 76.53$ & $\$ 78.25$ & & & $\$ 80.96$ \\
\hline & & & & $700-799$ & & & . & $\$ 79.13$ & & $\$ 76.75$ & $\$ 79.63$ & $\$ 75.79$ & $\$ 77.71$ & & & $\$ 78.54$ \\
\hline & & & & $800-899$ & & & . & $\$ 71.00$ & & $\$ 77.75$ & $\$ 75.76$ & $\$ 73.46$ & $\$ 69.75$ & & & $\$ 75.23$ \\
\hline & & & & $900-999$ & & & . & & & $\$ 76.88$ & $\$ 70.57$ & $\$ 69.93$ & & . & & $\$ 70.61$ \\
\hline & & & & $\begin{array}{l}1000- \\
1099\end{array}$ & & & . & & & & & $\$ 67.50$ & & & & $\$ 67.50$ \\
\hline & & & BWF & $600-699$ & & & 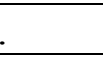 & $\$ 86.11$ & & & & $\$ 77.95$ & $\$ 77.69$ & & & $\$ 82.39$ \\
\hline & & & & $700-799$ & & & . & $\$ 80.38$ & & & $\$ 80.87$ & $\$ 75.58$ & $\$ 77.13$ & & & $\$ 78.99$ \\
\hline & & & & 800-899 & & & . & $\$ 69.75$ & & $\$ 76.50$ & $\$ 75.01$ & $\$ 73.96$ & & . & & $\$ 74.28$ \\
\hline & & & & $900-999$ & & & . & & & $\$ 76.00$ & $\$ 69.63$ & $\$ 68.81$ & & . & & $\$ 71.39$ \\
\hline & & & & $\begin{array}{l}1000- \\
1099\end{array}$ & & & . & & & & $\$ 64.00$ & & & . & & $\$ 64.00$ \\
\hline & & & Charolais & $400-499$ & & & • & $\$ 81.00$ & & & & & & . & & $\$ 81.00$ \\
\hline & & & & $500-599$ & & & . & $\$ 87.00$ & & & $\$ 74.00$ & & & . & & $\$ 80.50$ \\
\hline & & & & $600-699$ & & & . & $\$ 82.56$ & & & $\$ 78.00$ & $\$ 76.08$ & $\$ 75.44$ & & & $\$ 78.17$ \\
\hline & & & & 700-799 & & & . & $\$ 72.50$ & & $\$ 76.75$ & $\$ 78.86$ & $\$ 73.00$ & $\$ 77.25$ & & & $\$ 76.74$ \\
\hline & & & & $800-899$ & & & . & . & & $\$ 77.92$ & $\$ 75.67$ & $\$ 71.00$ & & . & & $\$ 75.88$ \\
\hline & & & Hereford & $700-799$ & & & . & . & & $e^{\circ}$ & $e^{\circ}$ & $\$ 74.25$ & & . & & $\$ 74.25$ \\
\hline & & & Limousin & $500-599$ & & & $\cdot$ & $\$ 84.00$ & & . & . & . & . & . & & $\$ 84.00$ \\
\hline & & & & $600-699$ & & & 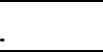 & $\$ 75.00$ & & 1 & 1 & $\$ 74.50$ & & . & & $\$ 74.75$ \\
\hline
\end{tabular}




\begin{tabular}{|c|c|c|c|c|c|c|c|c|c|c|c|c|c|c|c|c|}
\hline Year & Gender & Grade & Breed & Weight & Jan & Feb & Mar & Apr & Jun & Jul & Aug & Sep & Oct & Nov & Dec & Total \\
\hline \multirow[t]{31}{*}{1988} & Steers & $\mathrm{L}$ & Black & $800-899$ & & & & & & 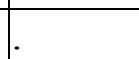 & & $\$ 72.00$ & & & & $\$ 72.00$ \\
\hline & & & & $700-799$ & & & & & & . & & $\$ 73.25$ & & & 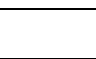 & $\$ 73.25$ \\
\hline & & & $\operatorname{Red} X$ & $600-699$ & & & & & & & & & $\$ 77.75$ & & & $\$ 77.75$ \\
\hline & & & & $700-799$ & & & & & & 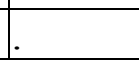 & $\$ 78.67$ & & & & 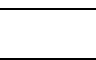 & $\$ 78.67$ \\
\hline & & & & $800-899$ & & & & & & $\$ 77.88$ & & $\$ 74.00$ & & & & $\$ 76.58$ \\
\hline & & S & Black & $400-499$ & & & & $\$ 79.25$ & & & 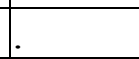 & & . & & 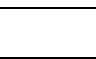 & $\$ 79.25$ \\
\hline & & & & 500-599 & & & & $\$ 84.25$ & & . & $\$ 75.50$ & & 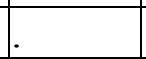 & & - & $\$ 81.33$ \\
\hline & & & & $600-699$ & & & & $\$ 81.50$ & & + & $\$ 79.00$ & $\$ 80.33$ & $\$ 71.00$ & & 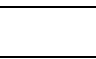 & $\$ 76.81$ \\
\hline & & & & $700-799$ & & & & . & & 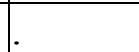 & $\$ 74.25$ & $\$ 75.50$ & & & & $\$ 74.88$ \\
\hline & & & Charolais & $400-499$ & & & & $\$ 70.50$ & & . & 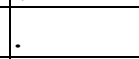 & . & . & 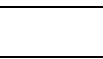 & & $\$ 70.50$ \\
\hline & & & & $500-599$ & & & & $\$ 74.00$ & & 1 & . & 1 &. & & & $\$ 74.00$ \\
\hline & & & Limousin & $400-499$ & & & & $\$ 74.00$ & & . & . & . & . & 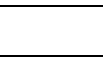 & & $\$ 74.00$ \\
\hline & & $\mathrm{FG}$ & Black & $600-699$ & & & & $\$ 88.00$ & & . & . & . & . & & & $\$ 88.00$ \\
\hline & & & Limousin & $600-699$ & & & & $\$ 86.00$ & & $f$ & . & 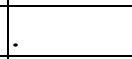 & . & & & $\$ 86.00$ \\
\hline & Heifers & $\mathrm{L}$ & Black & $600-699$ & & & & -1 & & . & & $\$ 71.25$ & $\$ 70.50$ & & & $\$ 70.69$ \\
\hline & & & & 700-799 & & & & $\$ 64.75$ & & $\$ 72.00$ & $\$ 73.38$ & $\$ 70.83$ & & & & $\$ 70.86$ \\
\hline & & & & $800-899$ & & & & & & $\$ 71.25$ & & $\$ 65.50$ & & & & $\$ 68.38$ \\
\hline & & & & $900-999$ & & & & & & & & $\$ 55.00$ & & & & $\$ 55.00$ \\
\hline & & & Charolais & $600-699$ & & & & & & . & $\$ 73.75$ & $\$ 62.00$ & & & & $\$ 67.88$ \\
\hline & & & & $700-799$ & & & & & & $\$ 73.94$ & $\$ 73.00$ & $\$ 67.00$ & & & & $\$ 72.68$ \\
\hline & & & Limousin & 500-599 & & & & $\$ 77.00$ & & & & & . & & & $\$ 77.00$ \\
\hline & & & & $700-799$ & & & & & & & $\$ 73.25$ & & . & & & $\$ 73.25$ \\
\hline & & & $\operatorname{Red} X$ & 700-799 & & & & . & & . & $\$ 71.00$ & &. & 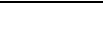 & & $\$ 71.00$ \\
\hline & & $\mathrm{M}$ & Black & 400-499 & & & & $\$ 82.50$ & & $f$ & &. & . & - & & $\$ 82.50$ \\
\hline & & & & 500-599 & & & & $\$ 82.00$ & & 1 & . & . & . & & & $\$ 82.00$ \\
\hline & & & & $600-699$ & & & & $\$ 70.35$ & & $\$ 76.00$ & $\$ 73.89$ & $\$ 71.46$ & $\$ 67.83$ & & & $\$ 72.30$ \\
\hline & & & & $700-799$ & & & 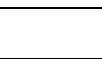 & $\$ 67.88$ & & $\$ 75.13$ & $\$ 75.11$ & $\$ 72.56$ & & & & $\$ 74.10$ \\
\hline & & & & $800-899$ & & & 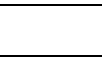 & . & & $\$ 75.25$ & $\$ 69.88$ & $\$ 65.25$ & & & & $\$ 67.18$ \\
\hline & & & & $900-999$ & & & & . & & . & & $\$ 66.50$ & & & & $\$ 66.50$ \\
\hline & & & BWF & $400-499$ & & & & $\$ 82.50$ & & . & & 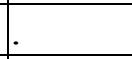 & |. & & & $\$ 82.50$ \\
\hline & & & & $600-699$ & & & & $\$ 69.85$ & & 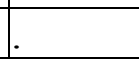 & $\$ 77.50$ & $\$ 71.75$ & & & & $\$ 70.73$ \\
\hline
\end{tabular}




\begin{tabular}{|c|c|c|c|c|c|c|c|c|c|c|c|c|c|c|c|c|}
\hline Year & Gender & Grade & Breed & Weight & Jan & Feb & Mar & Apr & Jun & Jul & Aug & Sep & Oct & Nov & Dec & Total \\
\hline \multirow[t]{13}{*}{1988} & Steers & $\mathrm{L}$ & Black & $800-899$ & & & & & & & & $\$ 72.00$ & & & - & $\$ 72.00$ \\
\hline & & & & $700-799$ & & & & $\$ 66.25$ & & $\$ 74.88$ & $\$ 74.31$ & $\$ 71.50$ & & & 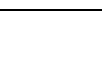 & $\$ 72.92$ \\
\hline & & & & $800-899$ & & & & & & $\$ 75.25$ & & t & . & 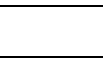 & 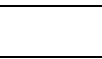 & $\$ 75.25$ \\
\hline & & & Charolais & $500-599$ & & & & $\$ 75.00$ & & . & . & . & . & 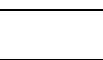 & 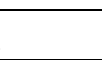 & $\$ 75.00$ \\
\hline & & & & $600-699$ & & & 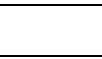 & $\$ 72.00$ & & $\$ 77.25$ & & $\$ 72.50$ & & 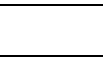 & 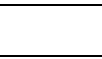 & $\$ 73.92$ \\
\hline & & & & $700-799$ & & & & 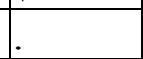 & & $\$ 75.67$ & $\$ 74.05$ & & ]$^{\circ}$ & & 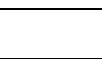 & $\$ 75.02$ \\
\hline & & & & $800-899$ & & & & . & & 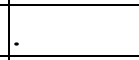 & & $\$ 70.00$ & & 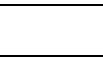 & 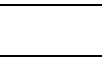 & $\$ 70.00$ \\
\hline & & & Mixed & $700-799$ & & & & 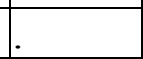 & & $\$ 75.88$ & & & . & & 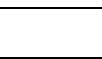 & $\$ 75.88$ \\
\hline & & & $\operatorname{Red~X}$ & $700-799$ & & & & - & & $\$ 76.00$ & & . & . & & 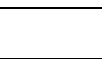 & $\$ 76.00$ \\
\hline & & & & $800-899$ & & & & 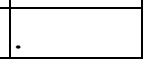 & & $\$ 75.25$ & & & $t$ & - & 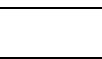 & $\$ 75.25$ \\
\hline & & S & Black & 500-599 & & & & $\$ 71.00$ & & & & & . & & 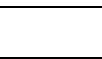 & $\$ 71.00$ \\
\hline & & & & $600-699$ & & & & + & & $\$ 72.50$ & & . & $\$ 62.25$ & & 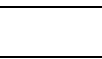 & $\$ 67.38$ \\
\hline & & & & 700-799 & & & & $t$ & & $\$ 68.00$ & & & & & 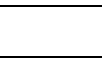 & $\$ 68.00$ \\
\hline \multirow[t]{15}{*}{1998} & Steers & $\mathrm{L}$ & Black & $600-699$ & & & & . & & & & $\$ 62.38$ & $\$ 63.42$ & & 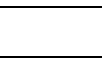 & $\$ 63.00$ \\
\hline & & & & 700-799 & & & &. & & 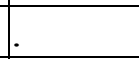 & . & $\$ 59.83$ & $\$ 69.00$ & & 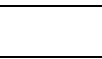 & $\$ 62.13$ \\
\hline & & & & 800-899 & & & & $\$ 73.25$ & & $\$ 64.50$ & $\$ 63.75$ & $\$ 59.13$ & $\$ 61.50$ & & 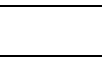 & $\$ 63.68$ \\
\hline & & & & $900-999$ & & & & -1 & & $\$ 61.75$ & & $\$ 58.17$ & $\$ 55.50$ & & 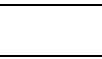 & $\$ 58.35$ \\
\hline & & & & $\begin{array}{l}1000- \\
1099\end{array}$ & & & & . & & & & $\$ 51.75$ & & & 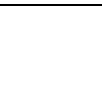 & $\$ 51.75$ \\
\hline & & & BWF & $800-899$ & & & & $\cdot$ & & $\$ 65.50$ & & . & . & & 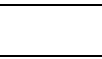 & $\$ 65.50$ \\
\hline & & & Charolais & $600-699$ & & & & . & & t & . & $\$ 60.50$ & $\$ 62.25$ & & 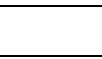 & $\$ 61.38$ \\
\hline & & & & 700-799 & & & 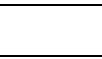 & . & & $\$ 68.50$ & $\$ 66.75$ & $\$ 60.00$ & $\$ 66.50$ & & 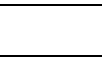 & $\$ 65.44$ \\
\hline & & & & $800-899$ & & & 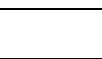 & . & & $\$ 64.75$ & $\$ 63.44$ & $\$ 60.95$ & $\$ 62.25$ & & 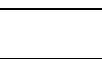 & $\$ 62.50$ \\
\hline & & & & $900-999$ & & & & 7 & & $\$ 62.00$ & & $\$ 56.67$ & & 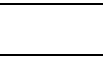 & 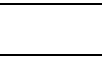 & $\$ 58.80$ \\
\hline & & & & $\begin{array}{l}1000- \\
1099\end{array}$ & & & & & & & & $\$ 50.25$ & & & 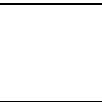 & $\$ 50.25$ \\
\hline & & & Hereford & $\begin{array}{l}1000- \\
1099\end{array}$ & & & & . & & . & & $\$ 53.00$ & & & 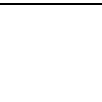 & $\$ 53.00$ \\
\hline & & & Limousin & $900-999$ & & & & . & &. &. & 4 & $\$ 57.25$ & & 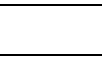 & $\$ 57.25$ \\
\hline & & & $\operatorname{Red} X$ & $800-899$ & & & & . & & $\$ 63.38$ & $\$ 62.50$ & & . & & 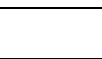 & $\$ 62.85$ \\
\hline & & & & $900-999$ & & & & 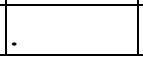 & & $\$ 61.75$ & &. & $T$ & & 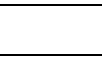 & $\$ 61.75$ \\
\hline
\end{tabular}




\begin{tabular}{|c|c|c|c|c|c|c|c|c|c|c|c|c|c|c|c|c|}
\hline Year & Gender & Grade & Breed & Weight & Jan & Feb & Mar & Apr & Jun & Jul & Aug & Sep & Oct & Nov & Dec & Total \\
\hline \multirow{30}{*}{1988} & Steers & $\mathrm{L}$ & Black & $800-899$ & & & & & & . & & $\$ 72.00$ & & & 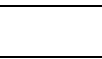 & $\$ 72.00$ \\
\hline & & $\mathrm{M}$ & Black & 400-499 & & & & $\begin{array}{l}\$ 103.0 \\
0\end{array}$ & & $\cdot$ & &. & . & & 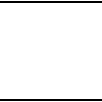 & $\begin{array}{l}\$ 103.0 \\
0\end{array}$ \\
\hline & & & & $500-599$ & & & & $\$ 97.25$ & & $f$ & & . & & & 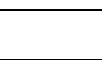 & $\$ 97.25$ \\
\hline & & & & 600-699 & & & & $\$ 89.33$ & & $\$ 70.00$ & & $\$ 67.00$ & $\$ 69.50$ & & 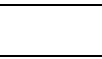 & $\$ 72.96$ \\
\hline & & & & $700-799$ & & & 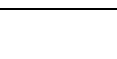 & $\$ 76.63$ & & $\$ 66.50$ & $\$ 66.86$ & $\$ 64.55$ & $\$ 68.42$ & & 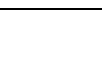 & $\$ 66.81$ \\
\hline & & & & $800-899$ & & & & $\$ 76.25$ & & $\$ 65.39$ & $\$ 64.72$ & $\$ 63.31$ & $\$ 64.58$ & & - & $\$ 65.04$ \\
\hline & & & & $900-999$ & & & & + & & $\$ 64.50$ & $\$ 62.33$ & $\$ 60.50$ & & & 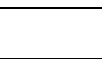 & $\$ 62.43$ \\
\hline & & & BWF & $500-599$ & & & & $\$ 98.00$ & & & & & & & 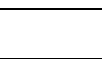 & $\$ 98.00$ \\
\hline & & & & $600-699$ & & & & $\$ 89.83$ & & & & $\$ 67.63$ & $\$ 70.13$ & & 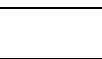 & $\$ 77.86$ \\
\hline & & & & $700-799$ & & & & $\$ 77.00$ & & $\$ 66.50$ & $\$ 66.73$ & $\$ 64.67$ & $\$ 68.42$ & & 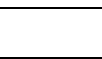 & $\$ 67.27$ \\
\hline & & & & $800-899$ & & & & $\$ 76.25$ & & $\$ 65.00$ & $\$ 65.00$ & $\$ 63.06$ & & & 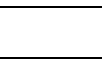 & $\$ 65.22$ \\
\hline & & & & $900-999$ & & & & . & & $\$ 62.25$ & & $\$ 58.25$ & & & 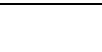 & $\$ 59.25$ \\
\hline & & & Charolais & $500-599$ & & & & $\$ 92.00$ & & & . & 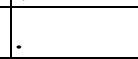 & 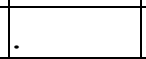 & & 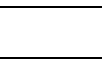 & $\$ 92.00$ \\
\hline & & & & 600-699 & & & & $u^{\circ}$ & & + & & $\$ 62.17$ & $\$ 67.50$ & & 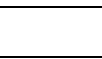 & $\$ 63.50$ \\
\hline & & & & $700-799$ & & & 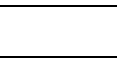 & . & & $\$ 67.75$ & $\$ 66.50$ & $\$ 63.83$ & $\$ 69.00$ & & 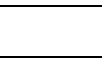 & $\$ 66.20$ \\
\hline & & & & $800-899$ & & & & & & $\$ 64.06$ & $\$ 64.00$ & $\$ 61.09$ & $\$ 66.00$ & & 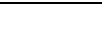 & $\$ 63.22$ \\
\hline & & & Hereford & $700-799$ & & & &. & & & $\$ 64.25$ & $\$ 64.50$ & & & 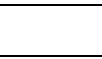 & $\$ 64.38$ \\
\hline & & & & $800-899$ & & & & & & $\$ 60.75$ & & $\$ 56.75$ & & & 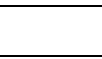 & $\$ 58.75$ \\
\hline & & & Limousin & 600-699 & & & & & & & & $\$ 63.00$ & & & 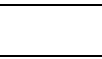 & $\$ 63.00$ \\
\hline & & & $\operatorname{Red} X$ & $600-699$ & & & & & & & & & $\$ 70.25$ & & & $\$ 70.25$ \\
\hline & & & & $700-799$ & & & & & & $\$ 67.00$ & $\$ 66.31$ & $\$ 66.50$ & $\$ 69.00$ & & 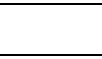 & $\$ 66.82$ \\
\hline & & & & $800-899$ & & & & & & $\$ 63.42$ & $\$ 64.13$ & $\$ 62.63$ & & & & $\$ 63.39$ \\
\hline & & $\mathrm{S}$ & Black & $400-499$ & & & & $\$ 93.00$ & & $\cdot$ & & $\cdot$ & . & & 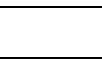 & $\$ 93.00$ \\
\hline & & & & $500-599$ & & & & $\$ 91.00$ & & . & . & . & $f^{\circ}$ & & 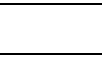 & $\$ 91.00$ \\
\hline & & & & $600-699$ & & & & $\$ 88.00$ & & . & & $\$ 69.00$ & $\$ 53.00$ & & 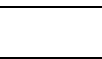 & $\$ 70.00$ \\
\hline & & & & $700-799$ & & & 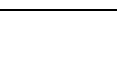 & . & & . & - & $\$ 62.50$ & & & 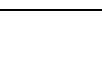 & $\$ 62.50$ \\
\hline & & & Charolais & $400-499$ & & & & $\$ 89.50$ & & . & & 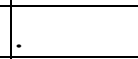 & $I^{\circ}$ & & 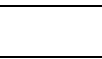 & $\$ 89.50$ \\
\hline & Heifers & $\mathrm{L}$ & Black & $500-599$ & & & 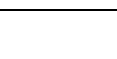 & . & & . & & $\$ 63.25$ & & & 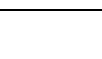 & $\$ 63.25$ \\
\hline & & & & $600-699$ & & & & & & & & $\$ 60.38$ & & & & $\$ 60.38$ \\
\hline & & & & $700-799$ & & & & 4 & & $\$ 64.25$ & $\$ 62.75$ & $\$ 59.75$ & $\$ 62.00$ & & & $\$ 62.11$ \\
\hline
\end{tabular}




\begin{tabular}{|c|c|c|c|c|c|c|c|c|c|c|c|c|c|c|c|c|}
\hline Year & Gender & Grade & Breed & Weight & Jan & Feb & Mar & Apr & Jun & Jul & Aug & Sep & Oct & Nov & Dec & Total \\
\hline \multirow[t]{26}{*}{1988} & Steers & $\mathrm{L}$ & Black & $800-899$ & & & & & & | & $e_{1}$ & $\$ 72.00$ & & & 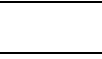 & $\$ 72.00$ \\
\hline & & & & $800-899$ & & & & & & 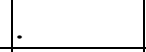 & & $\$ 56.25$ & $\$ 58.00$ & & & $\$ 57.13$ \\
\hline & & & BWF & $700-799$ & & & & & & & $\$ 62.75$ & & & & 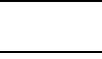 & $\$ 62.75$ \\
\hline & & & Charolais & 600-699 & & & & & & $\$ 64.25$ & & $\$ 60.88$ & & & 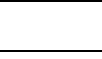 & $\$ 62.00$ \\
\hline & & & & $700-799$ & & & & & & $\$ 65.00$ & $\$ 62.60$ & $\$ 60.08$ & & & 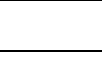 & $\$ 62.03$ \\
\hline & & & & 800-899 & & & & . & & $\$ 61.75$ & $\$ 61.50$ & & 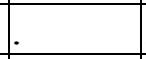 & & 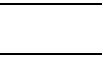 & $\$ 61.63$ \\
\hline & & & Limousin & $800-899$ & & & &. & & & & & $\$ 60.25$ & & 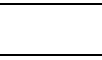 & $\$ 60.25$ \\
\hline & & & Red X & $700-799$ & & & &. & & $\$ 64.13$ & $\$ 61.75$ & $\$ 61.50$ & & 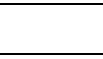 & 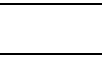 & $\$ 62.88$ \\
\hline & & $\mathrm{M}$ & Black & $400-499$ & & & & $\$ 84.00$ & & t & + & & . & 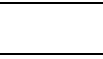 & 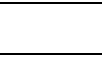 & $\$ 84.00$ \\
\hline & & & & $500-599$ & & & & $\$ 81.00$ & & 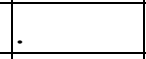 & 1 & T & 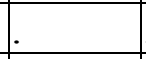 & 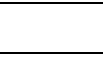 & 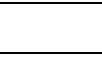 & $\$ 81.00$ \\
\hline & & & & 600-699 & & & & . & & $\$ 64.25$ & $\$ 64.00$ & $\$ 62.00$ & $\$ 64.25$ & & 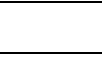 & $\$ 63.36$ \\
\hline & & & & $700-799$ & & & 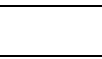 & . & & $\$ 62.80$ & $\$ 63.08$ & $\$ 62.46$ & & 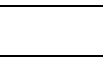 & 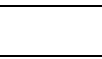 & $\$ 62.74$ \\
\hline & & & & $800-899$ & & & & . & & $\$ 60.88$ & $\$ 62.63$ & & . & 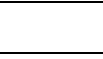 & 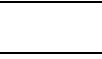 & $\$ 61.75$ \\
\hline & & & BWF & 500-599 & & & & $\$ 82.25$ & & 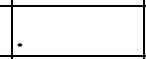 & $t$ & . & . & 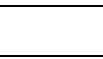 & 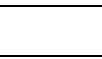 & $\$ 82.25$ \\
\hline & & & & 600-699 & & & & . & & $\$ 64.25$ & & $\$ 63.00$ & & 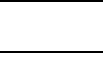 & 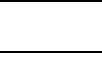 & $\$ 63.63$ \\
\hline & & & & $700-799$ & & & & . & & $\$ 64.00$ & & $\$ 62.33$ & $\$ 62.50$ & & 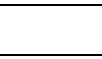 & $\$ 63.28$ \\
\hline & & & & $800-899$ & & & & 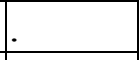 & & f & $\$ 61.50$ & & . & & 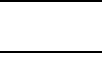 & $\$ 61.50$ \\
\hline & & & Charolais & $400-499$ & & & & $\$ 84.00$ & &. & 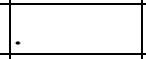 & f & . & & 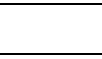 & $\$ 84.00$ \\
\hline & & & & $500-599$ & & & & $\$ 80.75$ & & . &. & . &. & & 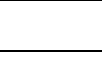 & $\$ 80.75$ \\
\hline & & & & $700-799$ & & & & & & $\$ 63.25$ & & t &. & & 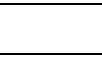 & $\$ 63.25$ \\
\hline & & & Limousin & 500-599 & & & & $\$ 83.00$ & & & $\cdot$ & & . & & 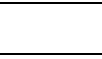 & $\$ 83.00$ \\
\hline & & $\mathrm{S}$ & Black & $400-499$ & & & & $\$ 76.75$ & & & . & & 1 & & 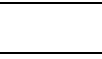 & $\$ 76.75$ \\
\hline & & & & $500-599$ & & & & $\$ 77.38$ & & - &. & $\$ 63.00$ & & & 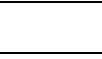 & $\$ 72.58$ \\
\hline & & & & 600-699 & & & & th & &. & . & $\$ 62.75$ & & & 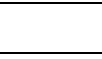 & $\$ 62.75$ \\
\hline & & & Charolais & $400-499$ & & & & $\$ 77.00$ & &. & 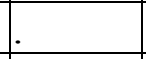 & 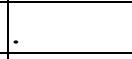 & $\cdot$ & & 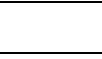 & $\$ 77.00$ \\
\hline & & & & $500-599$ & & & & $\$ 77.50$ & &. & $t$ & & & & 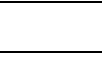 & $\$ 77.50$ \\
\hline \multirow[t]{5}{*}{1999} & Steers & $\mathrm{L}$ & Black & 600-699 & & & & $\$ 74.00$ & & . &. & $\$ 79.38$ & $\$ 75.00$ & & 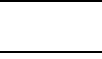 & $\$ 77.75$ \\
\hline & & & & $700-799$ & & & & $\$ 70.38$ & & . & $\$ 75.75$ & & . & & 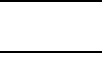 & $\$ 72.17$ \\
\hline & & & & $800-899$ & & & & $\$ 68.25$ & & $\$ 72.75$ & $\$ 72.50$ & & . & & 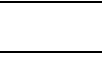 & $\$ 71.56$ \\
\hline & & & & $900-999$ & & & 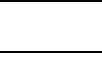 & . & & $\$ 64.25$ & $\$ 67.00$ & & $\cdot$ & 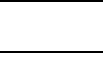 & 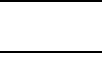 & $\$ 65.17$ \\
\hline & & & & $1000-$ & & & & 1 & &. & $\$ 61.25$ & & 1 & 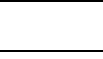 & 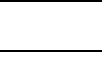 & $\$ 61.25$ \\
\hline
\end{tabular}




\begin{tabular}{|c|c|c|c|c|c|c|c|c|c|c|c|c|c|c|c|c|}
\hline Year & Gender & Grade & Breed & Weight & Jan & Feb & Mar & Apr & Jun & Jul & Aug & Sep & Oct & Nov & Dec & Total \\
\hline \multirow[t]{29}{*}{1988} & Steers & $\mathrm{L}$ & Black & $800-899$ & & & 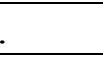 & & & & & $\$ 72.00$ & & . & & $\$ 72.00$ \\
\hline & & & & 1099 & & & & & & & & & & & & \\
\hline & & & BWF & $600-699$ & & & . & & & $e^{\cdot}$ & & & $\$ 80.50$ & & & $\$ 80.50$ \\
\hline & & & & $700-799$ & & & . & $\$ 72.88$ & & . & . & 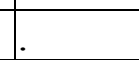 & 7 & . & & $\$ 72.88$ \\
\hline & & & Charolais & $600-699$ & & & . & $\$ 73.00$ & & + & & $\$ 67.00$ & $\$ 83.50$ & & & $\$ 74.50$ \\
\hline & & & & $700-799$ & & & . & 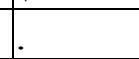 & . & $\$ 75.25$ & $\$ 75.75$ & $\$ 75.48$ & & . & & $\$ 75.40$ \\
\hline & & & & $800-899$ & & & . & . & & $\$ 71.94$ & $\$ 74.13$ & & . & . & & $\$ 72.67$ \\
\hline & & & Limousin & 500-599 & & & . & $\$ 77.00$ & & + & & & . & . & & $\$ 77.00$ \\
\hline & & & & $600-699$ & & & . & $\$ 71.50$ & & 5 & & & . & . & & $\$ 71.50$ \\
\hline & & & $\operatorname{Red} X$ & $700-799$ & & & . & & & $\$ 76.75$ & & & . & . & & $\$ 76.75$ \\
\hline & & & & 800-899 & & & . & . & & $\$ 72.45$ & $\$ 74.13$ & & & . & & $\$ 72.93$ \\
\hline & & & & $900-999$ & & & . & . & & $\$ 59.75$ & & & . & . & & $\$ 59.75$ \\
\hline & & $\mathrm{M}$ & Black & 500-599 & & & . & $\$ 86.06$ & & & & & &. & & $\$ 86.06$ \\
\hline & & & & $600-699$ & & & . & $\$ 83.25$ & & $\$ 76.00$ & $\$ 81.40$ & $\$ 77.92$ & & . & & $\$ 79.63$ \\
\hline & & & & 700-799 & & & . & $\$ 73.64$ & & $\$ 75.57$ & $\$ 77.28$ & $\$ 77.31$ & & . & & $\$ 76.18$ \\
\hline & & & & 800-899 & & & . & $\$ 72.06$ & & $\$ 71.79$ & $\$ 74.07$ & $\$ 72.50$ & & . & & $\$ 72.72$ \\
\hline & & & & $900-999$ & & & . & . & & . & $\$ 71.88$ & $\$ 65.00$ & & . & & $\$ 69.58$ \\
\hline & & & & $\begin{array}{l}1000- \\
1099\end{array}$ & & & . & . & & . & & $\$ 67.50$ & & . & & $\$ 67.50$ \\
\hline & & & & $\begin{array}{l}1200- \\
1299\end{array}$ & & & & & $\$ 68.00$ & & & & & . & & $\$ 68.00$ \\
\hline & & & BWF & 400-499 & & & - & $\$ 94.00$ & & & & & & . & & $\$ 94.00$ \\
\hline & & & & $600-699$ & & & . & $\$ 87.87$ & & $\$ 76.33$ & $\$ 79.50$ & $\$ 79.75$ & $\$ 83.50$ & & & $\$ 83.88$ \\
\hline & & & & 700-799 & & & . & $\$ 80.92$ & & $\$ 75.30$ & $\$ 76.75$ & & $\$ 76.75$ & & & $\$ 77.19$ \\
\hline & & & & $800-899$ & & & . & $\$ 74.00$ & & $\$ 75.13$ & $\$ 75.67$ & & 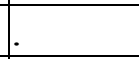 &. & & $\$ 75.21$ \\
\hline & & & & $900-999$ & & & . & . & & $\$ 69.75$ & $\$ 70.75$ & & . & . & & $\$ 70.25$ \\
\hline & & & Charolais & 400-499 & & & . & $\$ 87.00$ & &. & . & & 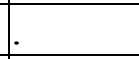 & . & & $\$ 87.00$ \\
\hline & & & & $500-599$ & & & . & $\$ 84.00$ & & . & & & + & . & & $\$ 84.00$ \\
\hline & & & & $600-699$ & & & . & $\$ 81.25$ & & $\$ 79.00$ & $\$ 79.50$ & $\$ 79.75$ & & . & & $\$ 80.33$ \\
\hline & & & & $700-799$ & & & . & $\$ 79.75$ & & $\$ 75.50$ & $\$ 77.00$ & $\$ 77.50$ & & . & & $\$ 76.91$ \\
\hline & & & & $800-899$ & & & . & & & $\$ 74.25$ & & & & . & & $\$ 74.25$ \\
\hline
\end{tabular}




\begin{tabular}{|c|c|c|c|c|c|c|c|c|c|c|c|c|c|c|c|c|}
\hline Year & Gender & Grade & Breed & Weight & Jan & Feb & Mar & Apr & Jun & Jul & Aug & Sep & Oct & Nov & Dec & Total \\
\hline \multirow{31}{*}{1988} & Steers & $\mathrm{L}$ & Black & $800-899$ & & & & & &. & & $\$ 72.00$ & & & 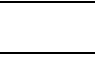 & $\$ 72.00$ \\
\hline & & & Hereford & 600-699 & & & & & & $\$ 73.50$ & & $\$ 74.00$ & & & 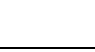 & $\$ 73.75$ \\
\hline & & & & $800-899$ & & & & & & . & $\$ 72.00$ & & . & & 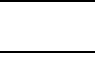 & $\$ 72.00$ \\
\hline & & & Limousin & $500-599$ & & & & $\$ 84.50$ & & 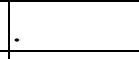 & & & & & 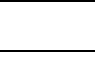 & $\$ 84.50$ \\
\hline & & & $\operatorname{Red} X$ & $600-699$ & & & & & & $\$ 73.50$ & $\$ 79.50$ & $\$ 74.21$ & & & & $\$ 75.13$ \\
\hline & & & & $700-799$ & & & & & & $\$ 74.50$ & $\$ 78.00$ & $\$ 71.19$ & & & 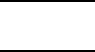 & $\$ 74.56$ \\
\hline & & & & 800-899 & & & & & & $\mu^{\circ}$ & & $\$ 73.50$ & & & 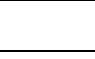 & $\$ 73.50$ \\
\hline & & $\mathrm{S}$ & Black & 400-499 & & & & $\$ 75.00$ & & . &. & . & $\cdot$ & 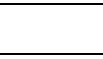 & 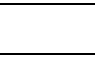 & $\$ 75.00$ \\
\hline & & & & $500-599$ & & & & $\$ 75.00$ & &. & $\$ 80.50$ & & . & & 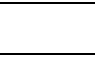 & $\$ 76.83$ \\
\hline & & & & $600-699$ & & & 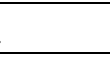 & $\$ 74.00$ & &. & 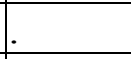 & $\cdot$ & . & - & 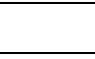 & $\$ 74.00$ \\
\hline & & & & $700-799$ & & & & 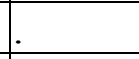 & & . & $\$ 75.50$ & & . & 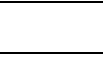 & 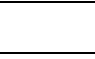 & $\$ 75.50$ \\
\hline & Heifers & $\mathrm{L}$ & Black & $400-499$ & & & 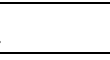 & $\$ 73.00$ & &. & 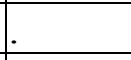 & . & . & 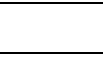 & 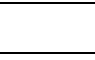 & $\$ 73.00$ \\
\hline & & & & $500-599$ & & & & $\$ 71.63$ & & . & + & . & . & - & 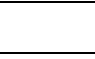 & $\$ 71.63$ \\
\hline & & & & $600-699$ & & & & $\$ 67.75$ & & 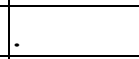 & 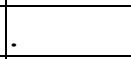 & . & . & 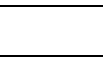 & 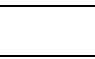 & $\$ 67.75$ \\
\hline & & & & $700-799$ & & & & $\$ 62.38$ & & $\$ 72.00$ & $\$ 72.25$ & & . & - & 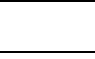 & $\$ 68.88$ \\
\hline & & & Charolais & $600-699$ & & & & 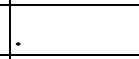 & & $\$ 74.25$ & & . & . & 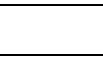 & 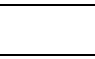 & $\$ 74.25$ \\
\hline & & & & $700-799$ & & & & $\$ 59.50$ & & $\$ 72.50$ & $\$ 72.00$ & & . & & 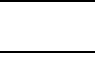 & $\$ 69.80$ \\
\hline & & & Limousin & $500-599$ & & & & $\$ 68.00$ & & 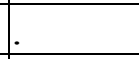 & & & . & & 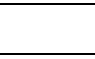 & $\$ 68.00$ \\
\hline & & & & $700-799$ & & & & & & $\$ 72.00$ & & & . & & 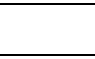 & $\$ 72.00$ \\
\hline & & & $\operatorname{Red} X$ & $600-699$ & & & & 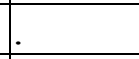 & & $\$ 74.25$ & $\$ 74.75$ & & . & & 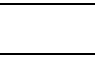 & $\$ 74.42$ \\
\hline & & & & $700-799$ & & & & . & & $\$ 72.00$ & $\$ 72.00$ & & . & & 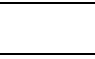 & $\$ 72.00$ \\
\hline & & $\mathrm{M}$ & Black & $400-499$ & & & & $\$ 75.88$ & & & & & & & 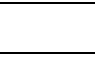 & $\$ 75.88$ \\
\hline & & & & $500-599$ & & & & $\$ 73.83$ & &. & . & $\$ 74.50$ & $\$ 71.00$ & & 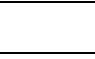 & $\$ 73.40$ \\
\hline & & & & $600-699$ & & & & $\$ 66.75$ & & $\$ 74.13$ & $\$ 73.63$ & $\$ 72.42$ & & & 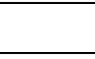 & $\$ 72.67$ \\
\hline & & & & $700-799$ & & & & $t_{1}$ & & $\$ 71.58$ & $\$ 73.25$ & $\$ 71.42$ & & & 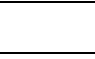 & $\$ 71.84$ \\
\hline & & & & $800-899$ & & & 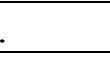 & 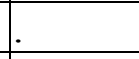 & & $\$ 70.00$ & & 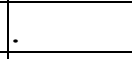 & . & & 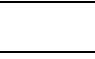 & $\$ 70.00$ \\
\hline & & & BWF & $400-499$ & & & & $\$ 75.00$ & & $\cdot$ & . & . & . & 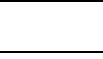 & 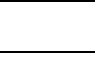 & $\$ 75.00$ \\
\hline & & & & $500-599$ & & & 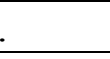 & $\$ 74.38$ & & 1 & $T$ & . & . & & 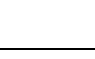 & $\$ 74.38$ \\
\hline & & & & $600-699$ & & & & $\$ 71.63$ & & $\$ 73.50$ & $\$ 74.75$ & & $\$ 75.75$ & & 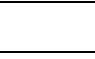 & $\$ 72.80$ \\
\hline & & & & $700-799$ & & & . & $\$ 70.75$ & & $\$ 72.50$ & $\$ 73.00$ & $\$ 72.38$ & & & 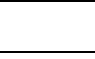 & $\$ 71.79$ \\
\hline & & & & $800-899$ & & & & $\$ 69.25$ & & $\$ 70.00$ & & & & & 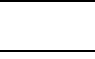 & $\$ 69.63$ \\
\hline
\end{tabular}




\begin{tabular}{|c|c|c|c|c|c|c|c|c|c|c|c|c|c|c|c|c|}
\hline Year & Gender & Grade & Breed & Weight & Jan & Feb & Mar & Apr & Jun & Jul & Aug & Sep & Oct & Nov & Dec & Total \\
\hline \multirow{11}{*}{1988} & Steers & $\mathrm{L}$ & Black & $800-899$ & & & & & & & & $\$ 72.00$ & & & & $\$ 72.00$ \\
\hline & & & Charolais & $600-699$ & & & & $\$ 70.50$ & & & & & & & & $\$ 70.50$ \\
\hline & & & & 700-799 & & & & $\$ 70.50$ & & $\$ 73.00$ & $\$ 73.00$ & & & & & $\$ 72.17$ \\
\hline & & & $\operatorname{Red} X$ & $600-699$ & & & & & & & $\$ 73.25$ & & & & & $\$ 73.25$ \\
\hline & & & & $700-799$ & & & & & & & & $\$ 71.50$ & & & & $\$ 71.50$ \\
\hline & & $\mathrm{S}$ & Black & $400-499$ & & & & $\$ 70.00$ & & & & & & & & $\$ 70.00$ \\
\hline & & & & $500-599$ & & & & & & $\$ 67.42$ & $\$ 74.75$ & & & & & $\$ 69.25$ \\
\hline & & & & $600-699$ & & & & $\$ 64.50$ & & $\$ 71.75$ & & & & & & $\$ 69.33$ \\
\hline & & & BWF & $400-499$ & & & & $\$ 69.38$ & & & & & & & & $\$ 69.38$ \\
\hline & & & & $500-599$ & & & & $\$ 67.75$ & & & & & & & & $\$ 67.75$ \\
\hline & & & & $700-799$ & & & & $\$ 70.00$ & & & & & & & & $\$ 70.00$ \\
\hline \multirow[t]{13}{*}{2000} & Steers & L & Black & $400-499$ & & & & & & & & $\begin{array}{l}\$ 107.0 \\
0\end{array}$ & & & & $\begin{array}{l}\$ 107.0 \\
0\end{array}$ \\
\hline & & & & $500-599$ & & & & & & & & $\begin{array}{l}\$ 102.5 \\
0\end{array}$ & & & & $\begin{array}{l}\$ 102.5 \\
0\end{array}$ \\
\hline & & & & $900-999$ & & & & & & & $\$ 72.75$ & & & & & $\$ 72.75$ \\
\hline & & & & $\begin{array}{l}1000- \\
1099\end{array}$ & & & & & & & $\$ 74.75$ & & & & & $\$ 74.75$ \\
\hline & & & BWF & $800-899$ & & & & & & & $\$ 83.00$ & & & & & $\$ 83.00$ \\
\hline & & & Charolais & $400-499$ & & & & & & & & $\begin{array}{l}\$ 100.5 \\
0\end{array}$ & & & & $\begin{array}{l}\$ 100.5 \\
0\end{array}$ \\
\hline & & & & $500-599$ & & & & & & & & $\begin{array}{l}\$ 105.5 \\
0\end{array}$ & & & & $\begin{array}{l}\$ 105.5 \\
0\end{array}$ \\
\hline & & & & $600-699$ & & & & & & & & & & $\$ 92.00$ & & $\$ 92.00$ \\
\hline & & & & $800-899$ & & & & & & & $\$ 82.55$ & & & & & $\$ 82.55$ \\
\hline & & & & 900-999 & & & & & & & $\$ 72.75$ & & & & & $\$ 72.75$ \\
\hline & & & & $\begin{array}{l}1000- \\
1099\end{array}$ & & & & & & & $\$ 74.75$ & & & & & $\$ 74.75$ \\
\hline & & & $\operatorname{Red} X$ & 800-899 & & & & & & & $\$ 84.00$ & & & & & $\$ 84.00$ \\
\hline & & M & Black & $400-499$ & & & & $\begin{array}{l}\$ 111.5 \\
0\end{array}$ & & & & $\begin{array}{l}\$ 108.1 \\
0\end{array}$ & & & & $\$ 108.6$ \\
\hline
\end{tabular}




\begin{tabular}{|c|c|c|c|c|c|c|c|c|c|c|c|c|c|c|c|c|}
\hline Year & Gender & Grade & Breed & Weight & Jan & Feb & Mar & Apr & Jun & Jul & Aug & Sep & Oct & Nov & Dec & Total \\
\hline 1988 & Steers & $\mathrm{L}$ & Black & $800-899$ & & & & & & & & $\$ 72.00$ & & & & $\$ 72.00$ \\
\hline & & & & $500-599$ & & & & $\begin{array}{l}\$ 104.2 \\
5\end{array}$ & & & & $\begin{array}{l}\$ 104.5 \\
0\end{array}$ & & & & $\begin{array}{l}\$ 104.4 \\
2\end{array}$ \\
\hline & & & & $600-699$ & & & & $\$ 94.00$ & & & $\$ 91.50$ & $\$ 86.67$ & $\$ 91.75$ & $\$ 92.50$ & & $\$ 90.63$ \\
\hline & & & & $700-799$ & & & & $\$ 84.63$ & & & $\$ 86.67$ & $\$ 82.94$ & $\$ 88.50$ & $\$ 89.63$ & & $\$ 86.29$ \\
\hline & & & & $800-899$ & & & & $\$ 78.25$ & & & $\$ 83.30$ & $\$ 76.64$ & $\$ 83.25$ & & & $\$ 82.47$ \\
\hline & & & & 900-999 & & & & $\$ 73.50$ & & & $\$ 77.05$ & $\$ 72.25$ & & & & $\$ 75.86$ \\
\hline & & & BWF & $400-499$ & & & & $\begin{array}{l}\$ 111.5 \\
0\end{array}$ & & & & $\begin{array}{l}\$ 107.5 \\
0\end{array}$ & & & & $\begin{array}{l}\$ 109.5 \\
0\end{array}$ \\
\hline & & & & $500-599$ & & & & $\begin{array}{l}\$ 101.5 \\
0\end{array}$ & & & & $\begin{array}{l}\$ 104.0 \\
0\end{array}$ & & & & $\begin{array}{l}\$ 103.1 \\
7\end{array}$ \\
\hline & & & & $600-699$ & & & & $\$ 94.00$ & & & $\$ 91.50$ & & & $\$ 91.75$ & & $\$ 92.19$ \\
\hline & & & & $700-799$ & & & & $\$ 85.00$ & & & $\$ 86.97$ & $\$ 81.75$ & $\$ 88.08$ & $\$ 91.50$ & & $\$ 87.02$ \\
\hline & & & & $800-899$ & & & & & & & $\$ 83.71$ & $\$ 75.00$ & & & & $\$ 83.09$ \\
\hline & & & & $900-999$ & & & & & & & $\$ 77.00$ & & & & & $\$ 77.00$ \\
\hline & & & & $\begin{array}{l}1000- \\
1099\end{array}$ & & & & & & & $\$ 74.75$ & & & & & $\$ 74.75$ \\
\hline & & & Charolais & $400-499$ & & & & $\begin{array}{l}\$ 107.0 \\
0\end{array}$ & & & & $\begin{array}{l}\$ 107.5 \\
0\end{array}$ & & & & $\begin{array}{l}\$ 107.2 \\
5\end{array}$ \\
\hline & & & & 700-799 & & & & & & & $\$ 86.88$ & & $\$ 88.25$ & $\$ 89.63$ & & $\$ 88.25$ \\
\hline & & & & $800-899$ & & & & & & & $\$ 82.94$ & & & & & $\$ 82.94$ \\
\hline & & & Hereford & $600-699$ & & & & & & & & & & $\$ 87.00$ & & $\$ 87.00$ \\
\hline & & & & $700-799$ & & & & & & & & & $\$ 83.50$ & & & $\$ 83.50$ \\
\hline & & & $\operatorname{Red} X$ & $700-799$ & & & & & & & & & $\$ 85.25$ & $\$ 89.63$ & & $\$ 87.44$ \\
\hline & & & & $800-899$ & & & & & & & $\$ 83.13$ & & & & & $\$ 83.13$ \\
\hline & & & & $\begin{array}{l}1000- \\
1099\end{array}$ & & & & & & & $\$ 74.75$ & & & & & $\$ 74.75$ \\
\hline & Heifers & $\mathrm{L}$ & Black & $500-599$ & & & & $\$ 87.50$ & & & & $\$ 88.50$ & & & & $\$ 88.17$ \\
\hline & & & & $600-699$ & & & & & & & & & & $\$ 82.50$ & & $\$ 82.50$ \\
\hline & & & & $700-799$ & & & & & & & $\$ 79.25$ & & $\$ 78.00$ & & & $\$ 78.63$ \\
\hline & & & BWF & 700-799 & & & & & & & & & $\$ 78.00$ & & & $\$ 78.00$ \\
\hline
\end{tabular}




\begin{tabular}{|c|c|c|c|c|c|c|c|c|c|c|c|c|c|c|c|c|}
\hline Year & Gender & Grade & Breed & Weight & Jan & Feb & Mar & Apr & Jun & Jul & Aug & Sep & Oct & Nov & Dec & Total \\
\hline \multirow[t]{17}{*}{1988} & Steers & $\mathrm{L}$ & Black & $800-899$ & & & 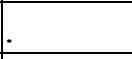 & & & & & $\$ 72.00$ & & . & 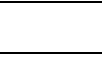 & $\$ 72.00$ \\
\hline & & & Charolais & 600-699 & & & & & & & $\$ 82.25$ & & & & & $\$ 82.25$ \\
\hline & & & & $700-799$ & & & . & & & & $\$ 80.63$ & & $\$ 78.00$ & & & $\$ 80.25$ \\
\hline & & & $\operatorname{Red} X$ & 600-699 & & & & & & & $\$ 82.25$ & & $\$ 84.75$ & & & $\$ 83.08$ \\
\hline & & & & $700-799$ & & & & & & & $\$ 80.75$ & & $\$ 78.00$ & & & $\$ 80.20$ \\
\hline & & $\mathrm{M}$ & Black & $400-499$ & & & . & $\$ 96.25$ & & & 1 & & 1 & . & 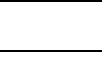 & $\$ 96.25$ \\
\hline & & & & $500-599$ & & & 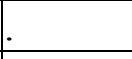 & $\$ 90.50$ & & & T & $\$ 88.50$ & & & & $\$ 89.50$ \\
\hline & & & & 600-699 & & & 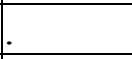 & $\$ 84.25$ & & & $\$ 81.50$ & $\$ 80.25$ & $\$ 84.75$ & $\$ 83.00$ & & $\$ 82.79$ \\
\hline & & & & $700-799$ & & & 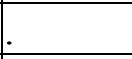 & $\$ 80.75$ & & & $\$ 82.08$ & $\$ 77.40$ & $\$ 78.50$ & & & $\$ 81.36$ \\
\hline & & & & $900-999$ & & & . & $\$ 71.00$ & & & . &. & . & te & 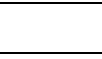 & $\$ 71.00$ \\
\hline & & & BWF & $400-499$ & & & $\cdot$ & $\$ 96.00$ & & &. &. &. & . & 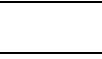 & $\$ 96.00$ \\
\hline & & & & $500-599$ & & & . & $\$ 90.25$ & & & 1 & $\$ 88.00$ & & 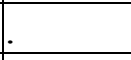 & 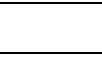 & $\$ 89.50$ \\
\hline & & & & $600-699$ & & & . & $0^{\circ}$ & & & $\$ 81.75$ & & $\$ 84.75$ & $\$ 82.50$ & & $\$ 83.00$ \\
\hline & & & & 700-799 & & & . & . & & & $\$ 81.95$ & & $\$ 78.50$ & & 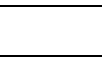 & $\$ 81.75$ \\
\hline & & & Charolais & $700-799$ & & & $\cdot$ & . & & & $\$ 83.20$ & &. & 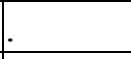 & 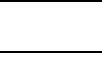 & $\$ 83.20$ \\
\hline & & & Hereford & 700-799 & & & 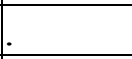 & 7 & & & $\$ 86.75$ & & . & 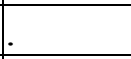 & 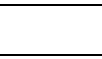 & $\$ 86.75$ \\
\hline & & & $\operatorname{Red~X}$ & $700-799$ & & & . & & & & $\$ 81.92$ & & 1 & 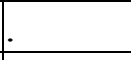 & 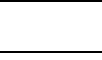 & $\$ 81.92$ \\
\hline \multirow[t]{13}{*}{2001} & Steers & $\mathrm{M}$ & Black & 600-699 & & & $\begin{array}{l}\$ 101.0 \\
0\end{array}$ & & & & $\$ 83.25$ & $\$ 92.45$ & $\$ 84.05$ & & & $\$ 90.51$ \\
\hline & & & & $700-799$ & & & $\$ 84.00$ & & & & $\$ 78.00$ & $\$ 87.32$ & $\$ 78.75$ & & & $\$ 85.33$ \\
\hline & & & & $800-899$ & & & 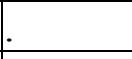 & & & & & $\$ 79.53$ & $\$ 75.63$ & & & $\$ 78.23$ \\
\hline & & & & $900-999$ & & & 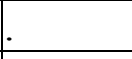 & & & & 1 & $\$ 77.24$ & $\$ 79.75$ & & 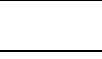 & $\$ 77.87$ \\
\hline & & & BWF & $700-799$ & & & 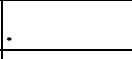 & & & & 1 & $\$ 79.00$ & & & & $\$ 79.00$ \\
\hline & & & & 800-899 & & & . & & & & $\$ 77.50$ & $\$ 78.50$ & & & & $\$ 78.00$ \\
\hline & & & & $900-999$ & & & & & & & $\$ 74.00$ & & $\$ 57.00$ & & & $\$ 65.50$ \\
\hline & & & Charolais & $600-699$ & & & . & & & & & & $\$ 79.13$ & $\$ 79.50$ & & $\$ 79.20$ \\
\hline & & & & 700-799 & & & T & & & & 1 & 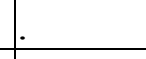 & $\$ 75.75$ & & & $\$ 75.75$ \\
\hline & & & & $800-899$ & & & 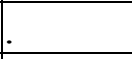 & & & &. & . &. & $\$ 76.00$ & & $\$ 76.00$ \\
\hline & & & & $900-999$ & & & 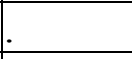 & & & & 1 & + & $T$ & $\$ 70.75$ & & $\$ 70.75$ \\
\hline & & & $\operatorname{Red} X$ & $600-699$ & & & 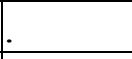 & $0^{\circ}$ & & &. &. & $\$ 74.50$ & & & $\$ 74.50$ \\
\hline & & & & $700-799$ & & & 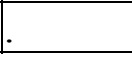 & & & & 1 & . & $\$ 78.75$ & $\$ 76.00$ & & $\$ 77.38$ \\
\hline
\end{tabular}




\begin{tabular}{|c|c|c|c|c|c|c|c|c|c|c|c|c|c|c|c|c|}
\hline Year & Gender & Grade & Breed & Weight & Jan & Feb & Mar & Apr & Jun & Jul & Aug & Sep & Oct & Nov & Dec & Total \\
\hline \multirow[t]{7}{*}{1988} & Steers & $\mathrm{L}$ & Black & $800-899$ & & T & . & & & & & $\$ 72.00$ & & . & & $\$ 72.00$ \\
\hline & Heifers & $\mathrm{M}$ & Black & $600-699$ & & & & & & & & $\$ 85.47$ & $\$ 73.29$ & & & $\$ 80.25$ \\
\hline & & & & $700-799$ & & 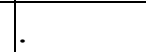 & . & & & & & $\$ 83.10$ & $\$ 70.92$ & & & $\$ 73.96$ \\
\hline & & & BWF & $700-799$ & & & . & & & & & $\$ 70.75$ & $\$ 71.50$ & & & $\$ 71.13$ \\
\hline & & & & $800-899$ & & & . & & & & & $\$ 71.25$ & $\$ 62.00$ & & & $\$ 66.63$ \\
\hline & & & Charolais & $600-699$ & & . & . & & & & . & & $\$ 71.17$ & $\$ 72.75$ & & $\$ 71.56$ \\
\hline & & & $\operatorname{Red} X$ & $700-799$ & & $e^{\circ}$ & . & & & & & & $\$ 70.25$ & & & $\$ 70.25$ \\
\hline \multirow[t]{20}{*}{2002} & Steers & $\mathrm{L}$ & Black & $700-799$ & & . & . &. & & & $\$ 75.50$ & $\$ 73.25$ & & . & & $\$ 74.75$ \\
\hline & & & & $800-899$ & & $\$ 79.00$ & & & & & $\$ 73.50$ & $\$ 71.50$ & & . & & $\$ 74.08$ \\
\hline & & & & $900-999$ & &. & . & & & & $\$ 64.00$ & $\$ 68.00$ & & . & & $\$ 66.00$ \\
\hline & & & & $\begin{array}{l}1000- \\
1099\end{array}$ & & & . & & & & $\$ 64.75$ & $\$ 66.83$ & & . & & $\$ 65.79$ \\
\hline & & & BWF & $800-899$ & & . & . & $\cdot$ & & & $\$ 73.25$ & & & . & & $\$ 73.25$ \\
\hline & & & & $\begin{array}{l}1000- \\
1099\end{array}$ & & & . & & & & $\$ 64.00$ & $\$ 66.25$ & & . & & $\$ 65.50$ \\
\hline & & & Charolais & $700-799$ & & $\cdot$ & . & & & & $\$ 75.50$ & $\$ 73.25$ & $\$ 79.75$ & +2 & & $\$ 76.17$ \\
\hline & & & & $800-899$ & &. & . & & & & $\$ 72.20$ & & + & . & & $\$ 72.20$ \\
\hline & & & & $900-999$ & & . & . & 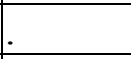 & & & $\$ 70.00$ & & . & . & & $\$ 70.00$ \\
\hline & & & & $\begin{array}{l}1000- \\
1099\end{array}$ & & & & & & & $\$ 64.38$ & & & . & & $\$ 64.38$ \\
\hline & & & Hereford & $\begin{array}{l}1000- \\
1099\end{array}$ & & & & & & & $\$ 64.00$ & & & . & & $\$ 64.00$ \\
\hline & & & $\operatorname{Red} X$ & $700-799$ & & & . & & & & $\$ 74.25$ & $\$ 74.13$ & & . & & $\$ 74.19$ \\
\hline & & & & $800-899$ & & . & . &. & & & $\$ 73.13$ & & . & . & & $\$ 73.13$ \\
\hline & & & & 900-999 & & . & . & 5 & & & $\$ 70.00$ & & ]$^{\circ}$ & . & & $\$ 70.00$ \\
\hline & & LM2 & Black & 600-699 & & . & . & . & & & $\$ 76.50$ & & 1 & . & & $\$ 76.50$ \\
\hline & & & & $800-899$ & & . & . & . & & & 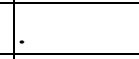 & & $\$ 70.00$ & +6 & & $\$ 70.00$ \\
\hline & & & Charolais & $700-799$ & & . & . & . & & & $\$ 69.25$ & &. & . & & $\$ 69.25$ \\
\hline & & & Hereford & $700-799$ & & . & . &. & & & $\$ 74.50$ & & . & . & & $\$ 74.50$ \\
\hline & & & & 900-999 & & 1 & . & . & & & $\$ 68.75$ & & & . & & $\$ 68.75$ \\
\hline & & $\mathrm{M}$ & Black & $600-699$ & & 1 & 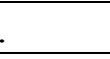 & $\$ 90.92$ & & & 1 & $\$ 79.38$ & $\$ 75.50$ & . & & $\$ 83.91$ \\
\hline
\end{tabular}




\begin{tabular}{|c|c|c|c|c|c|c|c|c|c|c|c|c|c|c|c|c|}
\hline Year & Gender & Grade & Breed & Weight & Jan & Feb & Mar & Apr & Jun & Jul & Aug & Sep & Oct & Nov & Dec & Total \\
\hline \multirow[t]{29}{*}{1988} & Steers & $\mathrm{L}$ & Black & $800-899$ & & & . & & & & & $\$ 72.00$ & & & & $\$ 72.00$ \\
\hline & & & & $700-799$ & & $\$ 76.17$ & $\$ 76.55$ & $\$ 75.00$ & & & $\$ 76.33$ & $\$ 77.79$ & $\$ 79.25$ & & & $\$ 77.92$ \\
\hline & & & & $800-899$ & & $\$ 78.40$ & $\$ 74.59$ & $\$ 72.00$ & & & $\$ 73.07$ & $\$ 73.03$ & $\$ 74.75$ & & & $\$ 73.84$ \\
\hline & & & & $900-999$ & & $\$ 75.40$ & $\$ 74.38$ & $\$ 69.00$ & & & $\$ 70.25$ & $\$ 71.22$ & & . & & $\$ 71.86$ \\
\hline & & & & $\begin{array}{l}1000- \\
1099\end{array}$ & & & . & & & & & $\$ 68.75$ & & . & & $\$ 68.75$ \\
\hline & & & BWF & $600-699$ & & & . & • & & & . & $\$ 81.25$ & &. & & $\$ 83.13$ \\
\hline & & & & $700-799$ & & $\$ 72.63$ & $\$ 77.25$ & & & & $\$ 76.80$ & $\$ 80.08$ & $\$ 79.38$ & & & $\$ 77.96$ \\
\hline & & & & 800-899 & & $\$ 80.50$ & & & & & $\$ 73.58$ & $\$ 73.13$ & $\$ 76.50$ & & & $\$ 74.38$ \\
\hline & & & & $900-999$ & & + & . & & & & $\$ 70.75$ & $\$ 70.70$ & & . & & $\$ 70.72$ \\
\hline & & & & $\begin{array}{l}1000- \\
1099\end{array}$ & & & . & & & & . & $\$ 68.13$ & &. & & $\$ 68.13$ \\
\hline & & & Charolais & $700-799$ & & . & . & & & & $\$ 75.50$ & $\$ 79.50$ & $\$ 78.25$ & & & $\$ 77.31$ \\
\hline & & & & $800-899$ & & & . & & & & $\$ 72.63$ & $\$ 73.00$ & &. & & $\$ 72.70$ \\
\hline & & & Hereford & $700-799$ & & + & . & & & & $\$ 73.25$ & & . & . & & $\$ 75.56$ \\
\hline & & & $\operatorname{Red} X$ & $600-699$ & & & . & & & & & $\$ 77.00$ & &. & & $\$ 77.00$ \\
\hline & & & & $700-799$ & & & . & & & & $\$ 77.00$ & $\$ 81.75$ & $\$ 79.50$ & & & $\$ 79.42$ \\
\hline & & & & $800-899$ & & & . & & & & $\$ 72.00$ & & & . & & $\$ 72.00$ \\
\hline & Heifers & $\mathrm{L}$ & Black & $700-799$ & & & . & & & & $\$ 70.83$ & & . & . & & $\$ 73.00$ \\
\hline & & & & 800-899 & & & . & & & & $\$ 70.13$ & $\$ 66.13$ & & . & & $\$ 68.13$ \\
\hline & & & BWF & $800-899$ & & & . & & & & & $\$ 67.00$ & & . & & $\$ 67.00$ \\
\hline & & & Charolais & 700-799 & & & . &. & & & $\$ 71.70$ & & $\cdot$ & . & & $\$ 73.00$ \\
\hline & & & & $800-899$ & & & . & . & & & $\$ 68.75$ & & . & . & & $\$ 68.75$ \\
\hline & & & $\operatorname{Red} X$ & $700-799$ & & & . & $\cdot$ & & & $\$ 71.63$ & & $t$ & . & & $\$ 71.63$ \\
\hline & & LM2 & Black & 700-799 & & & . & . & & & + & & . &. & & $\$ 78.50$ \\
\hline & & & BWF & 700-799 & & & . & . & & & $\$ 72.25$ & & . & . & & $\$ 72.25$ \\
\hline & & & Hereford & $700-799$ & & & . & . & & & . & & & . & & $\$ 78.50$ \\
\hline & & $\mathrm{M}$ & Black & $600-699$ & & & $\$ 71.80$ & $\$ 73.00$ & & & $\$ 72.31$ & $\$ 71.19$ & $\$ 75.50$ & & & $\$ 72.50$ \\
\hline & & & & $700-799$ & & & $\$ 70.83$ & & & & $\$ 71.39$ & $\$ 73.00$ & & . & & $\$ 72.08$ \\
\hline & & & & $800-899$ & & . & $\$ 64.50$ & $\$ 66.00$ & & & $\$ 69.00$ & $\$ 67.52$ & & . & & $\$ 67.26$ \\
\hline & & & BWF & $600-699$ & & & $\$ 70.00$ & $\$ 73.00$ & & & $\$ 74.00$ & & $\$ 75.50$ & & & $\$ 73.13$ \\
\hline
\end{tabular}




\begin{tabular}{|c|c|c|c|c|c|c|c|c|c|c|c|c|c|c|c|c|}
\hline Year & Gender & Grade & Breed & Weight & Jan & Feb & Mar & Apr & Jun & Jul & Aug & Sep & Oct & Nov & Dec & Total \\
\hline \multirow[t]{6}{*}{1988} & Steers & $\mathrm{L}$ & Black & $800-899$ & & & & & & 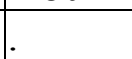 & & $\$ 72.00$ & & & & $\$ 72.00$ \\
\hline & & & & $700-799$ & & & $\$ 71.50$ & & & 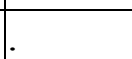 & $\$ 71.98$ & $\$ 74.00$ & & & & $\$ 72.59$ \\
\hline & & & & $800-899$ & & & & & & & $\$ 68.94$ & & . & & & $\$ 68.94$ \\
\hline & & & Charolais & $700-799$ & & & . & & & 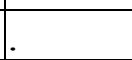 & $\$ 72.42$ & & . & & & $\$ 73.94$ \\
\hline & & & $\operatorname{Red~X}$ & $700-799$ & & & & & & & $\$ 71.25$ & $\$ 64.18$ & & & & $\$ 71.30$ \\
\hline & & & Smokie & $800-899$ & & & $\$ 64.50$ & & & & & & . & $\cdot$ & . & $\$ 64.50$ \\
\hline \multirow[t]{11}{*}{2003} & Steers & $\mathrm{L}$ & Black & $800-899$ & & & & & & . & 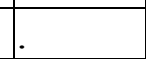 & $\$ 74.84$ & & . & & $\$ 74.84$ \\
\hline & & & Charolais & 800-899 & & & . & . & & . & . & $\$ 71.21$ & & . & . & $\$ 71.21$ \\
\hline & & M & Black & $600-699$ & & & & $\$ 88.00$ & & & & $\$ 94.18$ & $\begin{array}{l}\$ 102.0 \\
0\end{array}$ & & • & $\$ 94.73$ \\
\hline & & & & $700-799$ & $\$ 77.63$ & & & $\$ 87.00$ & & . & & $\$ 92.00$ & & . & . & $\$ 84.25$ \\
\hline & & & & $800-899$ & $\$ 78.00$ & & 1. & $\$ 70.00$ & & . & . & $\$ 87.46$ & & . & . & $\$ 78.37$ \\
\hline & & & BWF & $700-799$ & $\$ 78.75$ & & . & . & & . & . & . & . & . & . & $\$ 78.75$ \\
\hline & & & & $800-899$ & $\$ 77.00$ & & . & 4 & & . & . & . & . & . & . & $\$ 77.00$ \\
\hline & & & Red X & $700-799$ & & & . & 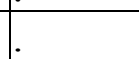 & & 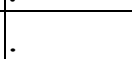 & & $\$ 76.05$ & & $0^{\circ}$ & & $\$ 76.05$ \\
\hline & Heifers & $\mathrm{M}$ & Black & $600-699$ & $\$ 74.00$ & & . & - & & . & . & ${ }^{\circ}$ & $1 \cdot$ & . & & $\$ 74.00$ \\
\hline & & & & $700-799$ & $\$ 75.75$ & & & & & & & & $F$ & & & $\$ 75.75$ \\
\hline & & & BWF & $600-699$ & $\$ 74.00$ & & & & & & & & $F$ & & & $\$ 74.00$ \\
\hline $\begin{array}{l}\text { Table } \\
\text { Total }\end{array}$ & $\begin{array}{l}\text { Price per } \\
\text { CWT }\end{array}$ & & & & $\$ 76.75$ & $\$ 76.76$ & $\$ 76.02$ & $\$ 77.85$ & $\$ 68.00$ & $\$ 69.67$ & $\$ 73.82$ & $\$ 72.86$ & $\$ 71.25$ & $\$ 76.34$ & & $\$ 73.62$ \\
\hline
\end{tabular}


VITA

\section{Matthew C. Kleski \\ 9278 Kleski Road SE \\ Uhrichsville, Ohio}

April 4, 1979

Born: Dennison, Ohio

June 1997

High School Graduation

Claymont High School

Uhrichsville, Ohio

June 2001

Bachelor of Science in

Agriculture

Major: Animal Science

Minor: Agribusiness and

Applied Economics

The Ohio State University

Columbus, Ohio

April 2001-October 2002

Director of Communications

and Promotions

Ohio Beef Council

Ohio Cattlemen's Association

Marysville, Ohio

January 2003-July 2004

Graduate Research Assistant

West Virginia University

Extension Service

Morgantown, West Virginia

May 2004

Master of Science in

Agriculture Education

West Virginia University

Morgantown, West Virginia 